\title{
História da Psicologia: Pesquisa, formação, ensino
}

\author{
Regina Helena de Freitas Campos \\ Organizadora
}




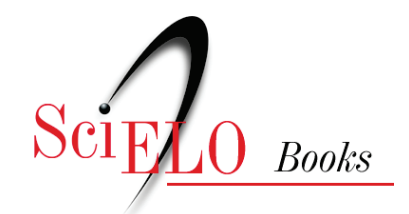

\section{História da psicologia \\ pesquisa, formação, ensino \\ Regina Helena de Freitas (org.)}

FREITAS, RH., org. História da psicologia: pesquisa, formação, ensino [online]. Rio de Janeiro: Centro Edelstein de Pesquisas Sociais, 2008. 133 p. ISBN: 978-85-99662-83-0. Available from

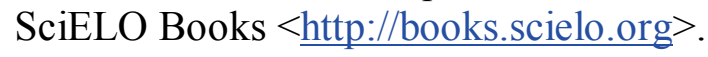

\section{(1) (1)(2)}

All the contents of this chapter, except where otherwise noted, is licensed under a Creative Commons Attribution-Non Commercial-ShareAlike 3.0 Unported.

Todo o conteúdo deste capítulo, exceto quando houver ressalva, é publicado sob a licença Creative Commons Atribuição Uso Não Comercial - Partilha nos Mesmos Termos 3.0 Não adaptada.

Todo el contenido de este capítulo, excepto donde se indique lo contrario, está bajo licencia de la licencia Creative Commons Reconocimento-NoComercial-CompartirIgual 3.0 Unported. 


\section{Regina Helena de Freitas \\ Organizadora}

\section{História da Psicologia: pesquisa, formação, ensino}

Centro edelstein de pesquisas sociais

Rio de Janeiro

2008 
Esta publicação é parte da Biblioteca Virtual de Ciências Humanas do Centro Edelstein de Pesquisas Sociais - www. bvce.org

Copyright (c) 2008, Regina Helena de Freitas Campos

Copyright (c) 2008 desta edição on-line: Centro Edelstein de Pesquisas Sociais Ano da última edição: 1996

Nenhuma parte desta publicação pode ser reproduzida ou transmitida por qualquer meio de comunicação para uso comercial sem a permissão escrita dos proprietários dos direitos autorais. A publicação ou partes dela podem ser reproduzidas para propósito não-comercial na medida em que a origem da publicação, assim como seus autores, seja reconhecida.

978-85-99662-83-0

Centro Edelstein de Pesquisas Sociais www.centroedelstein. org. br

Rua Visconde de Pirajá, 330/1205

I panema - Rio de Janeiro - RJ

CEP: 22410-000. Brasil

Contato: bvce@centroedelstein.org.br 


\section{SUMÁRIO}

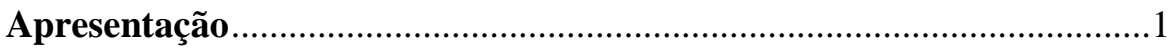

\section{PARTE I \\ A pesquisa em História da Psicologia}

Que fazem os historiógrafos?_Uma leitura de Josef Brožek Josef Brožek e Erlaine Guerra

Historiografia da Psicologia: métodos

Marina Massimi,_Regina Helena de Freitas Campos e Josef Brožek

Fontes em historiografia da psicologia Josef Brožek, Regina Helena de Freitas Campos

\section{PARTE II \\ Relatos de trajetórias de historiadores da psicologia}

Josef Brožek: relato de um historiador da psicologia Josef Brožek, Erlaine Guerra

Estudos históricos acerca da psicologia brasileira: uma contribuição Marina Massimi.

Algumas reflexões acerca de minha formação como pesquisadora em história da psicologia

Mitsuko Aparecida Makino Antunes

Em busca de um modelo teórico para o estudo da História da Psicologia no contexto sociocultural Regina Helena de Freitas Campos. 


\section{PARTE III \\ O ensino da história da psicologia}

História da Psicologia para curso de graduação

William B. Gomes

História da Psicologia: recurso para formação de pesquisadores e de psicólogos

Maria do Carmo Guedes 


\section{Apresentação}

Esta Coletânea, editada originalmente em 1996, resultou das atividades do Grupo de Trabalho em História da Psicologia, instituído por ocasião do VI Simpósio de Pesquisa e Intercâmbio Científico da Associação Nacional de Pesquisa e Pós-graduação em Psicologia, realizado em Teresópolis, Rio de Janeiro, em maio de 1966. A publicação reúne os trabalhos dos primeiros participantes do Grupo, pesquisadores e professores em diversas universidades brasileiras na área da História da Psicologia, e a contribuição do Professor Josef Brožek, da Universidade de Lehigh, EUA, convidado especial dessa primeira reunião.

Brožek (1913-2004) foi um dos pioneiros no estabelecimento do ensino e da pesquisa em História da Psicologia nos Estados Unidos, tendo sido co-fundador da Seção 26 da American Psychological Association, dedicada a essa área. Em 1965, junto com Robert Watson, participou da criação do periódico Journal of the History of the Behavioral Sciences, em cujo Conselho Editorial atuou por muitos anos. Com sua extensa experiência, o autor contribuiu com um importante testemunho da evolução dos estudos em História da Psicologia na América do Norte e na Europa, e sobre os métodos e fontes utilizados na pesquisa nessa área. Durante sua estadia entre nós, tivemos ainda a oportunidade de conhecer melhor a encantadora figura humana que ele era, e contar com seu apoio entusiástico ao trabalho de nosso Grupo.

A Coletânea foi organizada na forma de um manual de orientação para a pesquisa em História da Psicologia, para uso de professores e estudantes. Na primeira parte, e com base em sugestões e apontamentos do próprio Brožek em curso que lecionou na época a convite da Universidade de São Paulo em Ribeirão Preto, apresentamos três capítulos sobre a pesquisa em História da Psicologia: historiografia, métodos e fontes. A segunda parte traz os relatos da experiência e as reflexões de pesquisadores na área. A terceira parte trata do ensino em História da Psicologia e sua função na formação de pesquisadores e psicólogos.

Devemos um agradecimento especial à Professora Maria do Carmo Guedes, da Pontifícia Universidade Católica de São Paulo, por seu papel fundamental na promoção do intercâmbio acadêmico e científico entre 
pesquisadores interessados na História da Psicologia. Graças a seu esforço de aproximar os pesquisadores, por meio do trabalho do Núcleo de História da Psicologia do Programa de Estudos Pós-graduados em Psicologia Social da PUC-SP, este Grupo se constituiu e prossegue na tarefa de aprofundar e disseminar o interesse pelo conhecimento da evolução desse campo de conhecimento, seja no período pré-científico, seja no período em que a Psicologia atinge o status de ciência.

A publicação inicial foi possível pelo empenho das Professoras Elizabeth de Melo Bomfim e Teresinha Feres-Carneiro à frente da ANPEPP no período 1994-1996. A Coletânea foi editada na série Coletâneas da ANPEPP, com o $\mathrm{n}^{\circ} 15$.

Desde então, o Grupo de Trabalho em História da Psicologia da ANPEPP se ampliou, e continua a contribuir para a expansão da área dos estudos históricos em Psicologia em diversas universidades brasileiras. Os colegas do Grupo continuam a explorar caminhos ainda desconhecidos de nossa história, desenvolvendo novas abordagens e conhecimentos sobre os processos de construção dos conceitos e das práticas psicológicas.

É nossa convicção que o conhecimento do passado é condição essencial para a melhor orientação das escolhas feitas no presente, e para ampliar as bases da reflexão sobre a condição humana e sobre o papel das reflexões em Psicologia ao longo dessa trajetória. A riqueza e diversidade de leituras possíveis a relevância desse trabalho, que continua a nos desafiar.

Belo Horizonte, julho de 2008

Regina Helena de Freitas Campos

Organizadora 
PARTE I

A pesquisa em História da Psicologia 


\title{
Que fazem os historiógrafos? Uma leitura de Josef Brožek ${ }^{1}$
}

\author{
Josef Brožek* e Erlaine Guerra ${ }^{* *}$
}

Os relatos de eventos passados representam reconstruções baseadas em fragmentos deste passado. O historiador identifica os vestígios para poder coletá-los, organizá-los, analisá-los e interpretá-los. Descobre os documentos, fotografa e os transcreve, torna-os disponíveis. A recuperação de documentos é uma valiosa contribuição aos nossos conhecimentos. Todavia, estou de acordo que os documentos constituem a matéria-prima, dados crus da historiografia, não história mesma. Tornam-se história por meio de análise e elucidação.

Admito ser "alérgico" à aplicação da maioria dos grandes esquemas interpretativos existentes, sejam os esquemas da psicohistória enraizada na Psicanálise, sejam os esquemas clássicos dos marxistas soviéticos que reduzem a dinâmica do desenvolvimento da história da psicologia ao conflito entre o idealismo e o materialismo.

Tive uma confrontação com os colegas soviéticos no contexto da segunda reunião da sociedade psicológica soviética, que aconteceu em Leningrado em 1963, por causa desse tema.

Prefiro aderir fielmente aos dados e ligar a explanação à evidência. Concordo, porém, que uma história sem explanação se torna uma crônica, uma fileira de eventos apresentados em ordem cronológica, no fio do tempo.

Há dois fatos de importância fundamental: 1) é impossível registrar todos os fatos potencialmente relevantes; 2) é indispensável saber escolher os documentos para um estudo aprofundado. Em contraste com a pesquisa psicológica random sampling, o tirar amostras ao acaso não serve.

\footnotetext{
${ }^{1}$ O presente texto foi redigido a partir de anotações do Curso de História da Psicologia, ministrado pelo professor Brožek na USP de Ribeirão Preto, de 14 a 17 de maio de 1996. A segunda autora agradece a colaboração de Luciana S. Campanário na digitação das notas do Professor Brožek referentes aos exemplos de estudo quantitativo e surgimento de Cheiron.

* Professor na Lehigh University, nos Estados Unidos da América.

*** Mestranda em Psicologia pela Universidade Federal de Minas Gerais.
} 
Como podemos distinguir um vestígio trivial de um dado significante? Não existe regra. Às vezes, um dado relativamente isolado pode ter grande significado, por exemplo, a data de um manuscrito ou da morte de um autor. Quando procuramos a emergência de concepções maiores, duradouras, podemos sem perigo passar por cima de afirmações efêmeras, idiossincráticas.

A historiografia requer a coordenação da evidência, com o objetivo de produzir um relato coerente de uma faceta do passado. Este fornece a interpretação, uma tentativa de explanação. O historiador busca as relações entre os eventos. Uma síntese histórica deve ter raízes nos fatos, mas é preciso ir além da matéria-prima, para ver e apresentar os fatos na perspectiva.

\section{História como conduta}

Os acontecimentos que constituem o passado estudado pelos historiadores representam, na maior parte, ações de um indivíduo ou um grupo de indivíduos num tempo específico. Em outros termos, os eventos históricos representam formas de conduta. Como tais, os eventos são determinados, mesmo que tenham a ver com uma determinação complexa: alguns determinantes são imediatos, outros mais remotos no tempo; alguns são internos, outros são externos. Funcionam no quadro do desenvolvimento dos indivíduos (o que Hans Driesh, 1867-1941, denominou a base histórica de reação) e do Zeitgeist - o espírito do tempo (e às vezes de Ortsgeist - o espírito de lugar).

Para nós, como psicólogos, as realidades históricas básicas não são as guerras, o feudalismo, o partido democrático, nem a Renascença, a Idade da Razão, ou a Revolução Industrial. Olhando para trás percebemos a conduta de homens e mulheres concretos que vivem e escrevem no contexto de uma sociedade caracterizada pelas intenções, invenções e idéias.

Rigorosamente falando, a psicologia científica não tem emergido como resultado do casamento poligâmico da Filosofia, Física, Biologia e Fisiologia. Não: os atores são homens específicos. Pode ser um Ernest Heinrich Weber (1795-1878), professor de Anatomia e, mais tarde, de Fisiologia, que começou a estudar perto do ano de 1830 as relações entre a intensidade de estímulos e a intensidade das sensações (De pulsu, 
resorptione, auditu et tactu: Annotationes anatomicae et physiologicae, 1834). Pode ser um Franciscus Cornelis Donders (1818-1889), fisiólogo holandês, que estudou, aproximadamente no ano de 1865, a velocidade dos processos mentais. Herman Ebbinghaus (1850-1909), por exemplo, sem ajuda de ninguém, realizou experimentos sobre a memória, criando um importante capítulo da Psicologia contemporânea (Ueber das Gedaechtnis, 1885). A Psicofísica, a Psicometria e a Psicologia da Aprendizagem são as três colunas da Psicologia Experimental. Esta é uma abordagem psicológica à história - história de cientistas individuais.

Na sua abordagem ao estudo da história, o sociólogo dará ênfase ao papel de grupos, de instituições, de ideologias. Ambas as abordagens são válidas, e uma pode complementar a outra.

\section{Coletar e interpretar a evidência}

Em princípio, a pesquisa histórica não difere de outras categorias de pesquisa: Pesquisa Histórica $=\mathrm{E}$ (evidência) versus $\mathrm{T}$ (teoria). Evidência coordenada e interpretada pela teoria.

Este é um princípio, não uma receita. A receita é a aplicação de um princípio geral em uma situação específica. A pesquisa histórica envolve técnicas distintas da pesquisa de laboratório, clínica, ou de ambiente social. Não podemos mandar um questionário a Francis Galton (1822-1911), o versátil primo de Charles Darwin (1809-1882); não é possível fazer uma entrevista com ele. A pesquisa histórica pode exigir conhecimentos que ultrapassem a psicologia contemporânea, como a habilidade com línguas estrangeiras (alemão, francês, latim... de acordo com o tópico estudado). Conhecimentos básicos essenciais podem incluir física e matemática, biologia ou pedagogia, mas também geografia e a história geral do período que queremos estudar. É claro que nenhum indivíduo pode fazer tudo!

Podemos optar por limitar nossa pesquisa à história da psicologia numa área lingüística. Por exemplo, Brasil e Portugal; ou países onde se fala inglês. É aconselhável, no início, escolher uma área geográfica e lingüística limitada, para que o tema possa ser examinado a fundo. Consideremos por um momento a história da terminologia psicológica. Com o decorrer do tempo, os termos psicológicos mudam de sentido. Lamentavelmente, não existe um vocabulário histórico da psicologia (o 
melhor que temos é uma obra em língua alemã impressionante: Historisches Worterbuch der Philosofie, no seu oitavo volume). Por exemplo, quando li o termo tempo fisiológico em uma certa obra escrita em holandês (tradução do termo physiologische tijd), fiquei confuso para entender seu significado naquele contexto específico. Por fim pude constatar que o termo tem a ver com um antigo sinônimo do tempo de reação.

Problemas lingüísticos crescem quando regressamos no tempo. No relato a respeito do progresso das ciências, escrito por um cientista francês, De Maupertuis (em 1752), há uma parte na qual se fala, com espírito muito moderno, sobre experimentos psicológicos. Mas quais são os termos utilizados por De Maupertuis? Por exemplo, neste relato em língua francesa, no qual está escrito experiences metaphysiques, poderíamos simplesmente traduzir por experiências metafísicas?

\section{Da descrição à interpretação}

A historiografia começa com o relato de quem fez, o que fez, quando, e em que lugar, porém procura fazer um relato que explica não só "o quê" mas o "porquê".

Por que foi Wundt (1832-1920) e não, digamos, Helmholtz (18211894) quem estabeleceu o primeiro ou, ao menos, um dos primeiros laboratórios para a psicologia experimental? Por que isto aconteceu na Alemanha, e não na França, ou nos Estados Unidos? Por que os americanos responderam tão positivamente a Wundt e a seus Fundamentos de Psicologia Fisiológica (1873-74), ao esboço de uma psicologia construída segundo o modelo da fisiologia experimental, ficando pouco receptivos, se não esquecidos, de sua psicologia sociocultural, que Wundt chamou de Volkerpsychologie, a psicologia dos povos? Wundt levou a sério esta especialidade da psicologia, dedicando os últimos 20 anos de sua vida a este campo. Sua obra resultou em dez grandes volumes - uma terra incógnita na América.

A explanação é mais desejável que uma descrição. Ao mesmo tempo, dar uma explanação satisfatória não é uma tarefa fácil. Em primeiro lugar, só fragmentos do passado sobrevivem. Estaríamos em dificuldade se quiséssemos apresentar um quadro desse passado caracterizado pela 
continuidade, coerência e ordem. Raramente, ou, quase nunca, podemos fornecer soluções que sejam totalmente satisfatórias.

Podemos reconstruir o meio ambiente social, econômico, político, cultural e científico de um autor mais facilmente que o seu mundo interior, seu lugar próprio neste ambiente comum. Raramente, se não jamais, podemos determinar com confiança os motivos de outras pessoas.

Talvez devêssemos pensar e falar não das "causas”, mas das “condições”. As "causas” têm um sabor "fisicalístico”. O termo "causação” sugere a existência de antecedentes que invariavelmente são seguidos por efeitos específicos.

Na psicologia, eu sempre, e decididamente, preferi o modelo geral de conduta proposto por Woodworth (S-O-R, estímulo-organismoresposta) ao modelo S-R (estimulo-resposta) do behaviorismo clássico.

O modelo de Woodworth (1869-1962) tem a vantagem do paralelismo com as três categorias de dados históricos:

- fatos que concernem à situação,

- fatos acerca da gente que participa do evento, e

- fatos que se referem ao evento mesmo.

Alguns historiadores acham proveitoso diferenciar entre duas categorias ou classes de condições: 1) antecedentes e 2) agentes precipitantes.

Podemos considerar os antecedentes como condições gerais, condições que fazem possível um evento; os precipitantes são condições específicas, particulares, que fazem o evento inevitável.

$\mathrm{Na}$ perspectiva do modelo S-O-R da conduta, os eventos são condicionados por processos de estimulação externa e de estimulação interna (percepções, crenças, aspirações, expectativas).

Resumindo: as interpretações (explanações) dos historiadores baseiam-se na coleção, análise e síntese de dados (evidência), escolhidos na base de uma hipótese que pode vir a ser comprovada ou rejeitada. Os fatores não são estudados isoladamente, mas como partes de um sistema dinâmico de condições que determinam a conduta. 


\section{Perspectivas largas: historicismo contra presentismo}

Os historicistas insistem na compreensão de uma idéia, de um autor ou de uma abordagem no quadro de uma fatia do tempo. Devemos ter a cautela, continuam os historicistas, para evitar a intrusão, quase involuntária, do pensamento presente. $\mathrm{O}$ uso de conceitos e termos contemporâneos, digamos, "funcionalismo", "evolução" ou "condicionamento", no pensar de homens que viviam há muito tempo, conduz facilmente a anacronismo, isto é, a simplificação exagerada e interpretação errônea.

Uma visão retrospectiva, baseada nos conhecimentos e modelos contemporâneos, pode nos induzir, por exemplo, numa consideração de nossos antecedentes como ingênuos. As gerações seguintes podem aplicar os mesmos epítetos a nós mesmos. Por outro lado, o presentismo insiste no significado do passado, quando existe algum, para nossos dias. Facilmente, torna-se um preconceito com relação a esse passado, pois não podemos selecionar do passado só as idéias vistas como uma antecipação do presente. Esta estratégia tem seus aspectos positivos, seus interesses e seus méritos, porém as limitações e perigos do presentismo são muito mais agudos. Existe o perigo que o historiador presentista produza um relato que é nada menos que uma ratificação, ou uma glorificação do presente. A marcha da história é apresentada como um progresso contínuo de um passado ignorante aos nossos conhecimentos profundos e inevitáveis do presente. Nossos antepassados são considerados simplesmente como nossos precursores.

A idéia de que hoje vemos um caminho claro e seguro que deve nos conduzir para um futuro de grandes esperanças, seja na Ciência seja na vida política, seria verdadeira? Infelizmente as coisas parecem não ser assim. Como indivíduos, como membros de sociedades de psicologia, como sociedade, podemos estar mais conscientes de muitas alternativas do que de um caminho seguro para futuro.

Resumindo: para mim, ambas as abordagens possuem seus aspectos positivos e também seus perigos e limitações. Alguns de nós somos atraídos pela história vista como uma série de fatias horizontais; outros preferem ver a história como uma reconstrução vertical de temas e tendências escolhidas. 


\section{Modelos de história}

Consideraremos quatro modelos: 1) O Zeitgeist - o espírito do tempo; 2) Grandes homens; 3) Abordagem psicanalítica; e 4) Uma visão multifatorial.

\section{O Zeitgeist}

Podemos traduzir o termo alemão como o espírito (ou índole) do tempo.

Wolfgang Goethe (1749-1832), um poeta e pensador alemão, viu o Zeitgeist como um "conjunto de opiniões que dominam um momento específico da história e que, sem nosso saber, ou inconscientemente, formam o pensamento de todos os que vivem em seu contexto".

Menos poeticamente, utilizando uma terminologia antropológica, poderíamos falar da "cultura do dia, cultura dos tempos": os conhecimentos, as crenças, as atitudes das pessoas que vivem num tempo e num lugar específicos.

Em alemão, o conceito é menos abstrato, mais "reificado", transformado numa realidade concreta, quase num agente pessoalizado. Não só caracteriza e descreve, mas determina, controla a conduta da sociedade humana no tempo e lugar específicos.

É um conceito explanatório cujo valor para a história científica deve ter sido debatido arduamente. O conceito foi favorecido por Edwin G. Boring, o grande historiador norte-americano da Psicologia.

Segundo este modelo, o Zeitgeist produz idéias (como a "gravitação"), instituições (como casas editoriais ou periódicos) e movimentos científicos (como a psicologia experimental). O Zeitgeist faz tudo: se não existisse um Fechner (1801-1887), o fundador da psicofísica, o tempo, o Zeitgeist, produziria um substituto de Fechner. Sem Wilhelm Wundt, a psicologia experimental seria institucionalizada em outro lugar, por uma outra pessoa. A idéia, poderíamos dizer, penderia no ar: os tempos estariam prontos para a institucionalização da psicologia científica.

Ora, os homens, principalmente os Grandes Homens, são os agentes, agentes máximos, o Zeitgeist mesmo. 
Uma tal perspectiva, porém, não é totalmente sem mérito. Está claro que todos nós estamos imersos num ambiente lingüístico, socioeconômico, cultural, político específico.

O Zeitgeist é uma metáfora eficaz, simplifica e unifica relato histórico. Quando as metáforas são instrumentos de escolha não para a ciência, mas para a poesia, o conceito de Zeitgeist pode vir a sugerir a existência de um demiurgo ou demônio, que manipularia os cordões da história, gerando e aplicando forças.

Na realidade, o Zeitgeist é uma construção hipotética, um modo elegante de interpretar a conduta dos indivíduos e dos grupos de indivíduos.

O Zeitgeist é o fundo de um esquema interpretativo da história e, como tal, é útil na reconstrução e compreensão de eventos históricos. Como uma abordagem à explanação dos eventos históricos (por exemplo, o estabelecimento de um laboratório para pesquisa experimental psicológica em Leipzig em 1879) não basta. É uma simplificação exagerada, excessiva.

A idéia é útil para lembrar-nos de que conhecimentos, opiniões, dogmas do dia formam uma parte, parte importante, de nossa existência. São uma parte do complexo de estímulos a que os homens, inclusive os Grandes Homens, respondem.

\section{Grandes homens}

O conceito de Zeitgeist sugere a existência de uma "alma coletiva”. O conceito de "Grandes Homens” é situado num pólo oposto. Segundo este modelo, são os homens e as mulheres excepcionais que criam a história.

\section{Abordagem psicanalítica}

Fala-se de “psicohistória”. Em última análise, toda história é "psicohistória" - o estudo do comportamento dos homens e dos grupos de homens. Neste caso, falamos de "psicohistória" no sentido geral, sem limitar-nos à interpretação psicanalítica, freudiana. Desafortunadamente, a psicologia não foi capaz de oferecer aos historiadores um modelo da personalidade com que se possa contar e que seja útil ao historiador. A Psicologia científica põe ênfase no estudo das leis gerais do comportamento. O historiador está interessado no comportamento de indivíduos. 
Em anos relativamente recentes, emergiu uma variedade da psicohistória, muitas vezes apresentada como a psicohistória baseada na psicanálise. A psicanálise tem as suas raízes no estudo dos pacientes individuais e propôs um esquema interpretativo unificado de comportamento do cliente. Freud mesmo pode considerar-se como o primeiro historiador com a orientação psicanalítica (veja Leonardo da Vinci: Um estudo da personalidade, 1947, em inglês, publicado em alemão em 1910). A versão alemã tem um título mais modesto e mais instrutivo: Eine Kindheitscrinnerung des Leonardo da Vinci - Uma lembrança de Leonardo da Vinci).

Há um perigo genuíno de que um relato psicanalítico se torne, como diz Hugh Trevor-Roper ("Reinventing Hitler”, Sunday Times (London), 18 fevereiro de 1973), em um “conto de fadas clínico”: em lugar de começar com os fatos e proceder, cautelosamente, à interpretação da evidência, às conclusões, os historiadores da escola psicanalítica podem recriar os fatos na base de sua teoria.

Freud baseia seu relato, acima citado, nas fantasias de uma lembrança da infância de da Vinci. O pouco de informação que existe é interpretado de um modo gratuito. A psicanálise não prova ser um modelo satisfatório para a análise histórica, é um modelo sedutor.

\section{Uma visão multifatorial}

Os eventos históricos, como todos os eventos que concernem à conduta humana, são complexos. Este fato sugere a utilidade de uma metodologia pluralista. O modelo teve que acomodar uma variedade de estratégias; dirige a atenção do historiador a variáveis que podem ser examinadas empiricamente, e que suprem uma base válida para a síntese histórica. Ambos, o ator e o contexto, devem ser considerados.

R.F. Berhoffer (1969), no seu livro A behavioral approach to historical analysis - Uma abordagem condutual à análise histórica (NY: Free Press, 1969) especifica: “A tarefa primeira de uma análise histórica é considerar a situação em que o ator se acha, a sua interpretação da situação e as suas atividades na situação”. Não podemos esquecer que os indivíduos atuam uns sobre os outros e, deste modo, geram atividades coletivas. 


\section{Historiografia das idéias psicológicas}

O termo psychologia é o equivalente neo-grego de Peri psyches do grego clássico, o título de uma das obras de Aristóteles, De anima, no latim.

A história da origem do termo psychologia não é completamente clara. O problema é tópico que interessa, desde anos, à professora Marina Massimi e a mim. Esperamos completar, brevemente, um artigo que contribuirá para a solução deste antigo quebra-cabeça.

O que é claro é que o termo apareceu no começo do século XVI.

Conseqüentemente, no senso estrito, não podemos falar de "psicologia" e de história da psicologia antes do aparecimento deste termo.

Ao mesmo tempo, acho útil o termo idéias psicológicas.

No Brasil foi o professor Antônio Gomes Penna quem introduziu o termo no seu livro de 1980, intitulado História das idéias psicológicas. O livro começa com "a reflexão psicológica entre os primitivos" e passa às idéias psicológicas na Grécia, no pensamento cristão, na França, GrãBretanha e Alemanha, voltando à França de Maine de Biran e de Henri Bergson.

Marina Massimi, na sua História da psicologia brasileira: da época colonial até 1934, publicada no ano de 1990, dedica o primeiro capítulo aos conhecimentos psicológicos, quer dizer, idéias psicológicas no Brasil colonial. Inclui três setores: 1) Idéias psicológicas dos índios brasileiros, com ênfase na criança e na mulher da sociedade indígena; 2) Cultura católica do Brasil colonial, incluindo os conceitos e métodos psicopedagógicos dos jesuítas, o conhecimento de si mesmo, de paixões e da tristeza; 3) Idéias do século XVIII, terminando com idéias tocantes à fundação de uma ciência do homem.

O meu colega de Praga, professor Hoskovec e eu achamos o termo e o conceito de idéias psicológicas útil como título de um livro que será publicado em 1998, na ocasião das comemorações dos 650 anos da fundação da Universidade em Praga, Boemia, no ano de 1348. O livro apresentará as idéias psicológicas de autores tchecos, associados com a universidade, como alunos ou professores nesse largo período de tempo. 
As idéias psicológicas apresentadas nesse livro podem agrupar-se nas oito categorias que correspondem às seguintes disciplinas ou especialidades da psicologia: Psicopatologia (pessoas que têm o vício da bebida, o suicídio), Psicologia do desenvolvimento (criança, velhice), Psicologia educacional (o processo de aprender e de ensinar), Higiene mental (adaptação ao esforço/stress, na velhice), Personalidade (as necessidades psicológicas, ter ou não ter criança), Psicologia pastoral (os pecados e pecadores), Psicologia ocupacional (o trabalho humano), Psicologia política e social (caráter e conduta nacional, aspectos morais de nacionalidade, aprender línguas como uma abordagem da paz entre povos, partidos políticos, uma sociedade inspirada com, idéias morais).

A preparação de uma história deste gênero é um empreendimento novo, um empreendimento que desafia.

\section{História da psicologia - fontes de informação: a literatura}

Além das obras de consulta, há duas formas de literatura, a literatura primária e a literatura secundária.

A literatura primária refere-se aos livros originais e artigos nos jornais. Esta literatura, escrita em diversos idiomas, ocuparia o espaço de uma grande biblioteca.

A literatura secundária é constituída de monografias científicas, relativamente poucas, dedicadas aos indivíduos, temas especializados, sistemas e campos de psicologia, e de uma grande quantidade de livros escolares.

Um dos livros nesta última categoria que poderia ser de interesse é The story of psychology, uma obra modesta de Frank J. Bruno. A edição original apareceu no ano 1972 (NY: Holt, Rinehart \& Winston). A tradução em português, por Tomas Croft de Moura, foi publicada sete anos mais tarde, em 1979 (Lisboa: Sociocultura).

\section{Estudo quantitativo - exemplos de trabalhos}

1) Nossas análises historiométricas da literatura psicológica começaram com o estudo "do período da citação" ("citation longevity", longevidade da citação) como critério de importância histórica de uma obra. 
A obra específica era um artigo do fisiólogo holandês, F.C. Donders, intitulado - na sua versão alemã - "Die Schnelligkeir Psychischer Processe", publicado em uma revista importante, Archiv fuer Anatomie und Physiologie und wissenchaftliche Medizin - Arquivo de Anatomia, Fisiologia e Medicina Científica. O artigo apareceu no ano de 1868 e foi citado num período de cem anos. O número de citações aumentou nas décadas de 1940 e 1950, devido ao interesse dos psicólogos experimentais no problema de comunicação. O número máximo de citações ocorreu no ano de 1968, no centenário da publicação da versão alemã.

Os erros de edição e de tradução na versão em holandês exigiram um artigo à parte que publiquei no ano de 1970. Passei então a examinar a história da versão alemã. Neste exemplo nos cabe formular muitas questões: mas e quem leu (e quem citou) a versão holandesa do artigo? Quem leu (e citou) a tradução inglesa? Que importância têm a língua e a revista em que uma obra aparece para seu "significado" histórico?

2) Em outro estudo bibliométrico, as traduções de livros publicados no estrangeiro servem como critérios de observação do "clima" político e cultural de um país. O país de um trabalho que desenvolvi foi a Iugoslávia do pós-guerra.

No período da guerra o comunismo soviético ganhou a supremacia.

No ano de 1948, Tito mandou os representantes soviéticos para casa. O seu modelo de comunismo diferia profundamente do modelo soviético, com ênfase na "samonpravljanje". Os trabalhadores, não o Estado, deveriam ser os donos das fábricas. Stalin ficou furioso, e a guerra diplomática e econômica contra a Iugoslávia foi violenta. Paulatinamente, as relações históricas tradicionais de sérvios com a França e de Croatas com a Alemanha mostraram a sua vitalidade, e o crescente poder econômico e militar dos Estados Unidos emergiu como fator decisivo.

Esta contextualização histórica vem ilustrar como as traduções de livros psicológicos na Iugoslávia puderam ser tomadas como indicadores da dificuldade no pós-guerra com a crise geral na economia. As primeiras traduções foram de livros russos. Em meados dos anos 50 apareceram as primeiras traduções de livros franceses, seguidas pelas traduções de livros alemães. Finalmente, na década de 60 a literatura americana dominou. 
3) Em um terceiro estudo, coletamos dados de uma série de dissertações apresentadas na Universidade de Valencia, na Espanha, citadas na análise de quatro importantes revistas americanas. O número total de citações foi em torno de cem mil. Observando-se os idiomas das obras citadas, verificamos uma mudança sistemática com o passar do tempo. Para simplificar, quando comparamos a última década do século XIX com os anos de 1940 e 1945, verificamos que a porcentagem de citações de obras alemãs decresceu de $31 \%$ a $8 \%$, e as citações de obras francesas, de $11 \%$ a $2 \%$. Ao contrário, as citações de obras inglesas, preponderantemente norteamericanas, cresceram de $56 \%$ a $89 \%$.

4) De que forma uma análise quantitativa pode facilitar a compreensão de uma estrutura tão complexa como uma disciplina científica? Formulei esta pergunta na segunda metade da década de 60 mais do que dez anos desde a morte de Stalin (ano de 1953) e no começo de uma liberalização na sociedade soviética, mesmo uma liberalização relativa e parcial. A publicação dos jornais psicológicos na União Soviética terminou no começo da década de 30: as revistas Psicologia, Pedologia, e a Revista para o Estudo da Personalidade cessaram de ser publicadas no ano de 1932. A Psicotécnica soviética desapareceu dois anos mais tarde, no ano de 1934, e durante um período de 20 anos nenhuma revista da psicologia apareceu em russo. A revista Problemas da Psicologia surgiu no ano de 1955.

No ano de 1963 participei como delegado oficial da American Psychological Association, no segundo congresso da Sociedade Psicológica da União Soviética, que aconteceu em Leningrado.

Dois eventos marcaram o ano de 1966: 1) A reunião, em Moscou, do $18^{\circ}$ Congresso Internacional da Psicologia e 2) a transformação dos departamentos de psicologia das universidades de Moscou e de Leningrado em faculdades de psicologia.

Escolhi os catálogos da terceira reunião da Sociedade Soviética de Psicologia, de 1968, para uma análise quantitativa do seu conteúdo. O número de referências às especialidades de psicologia, como base para esboçar a estrutura da psicologia soviética no fim da década, no ano de 1968, foi 906 no total.

São os resultados: 


$\begin{array}{lrr}\text { Área } & \text { \% } & \\ \text { Psicologia da criança e da educação } & & 29,2 \\ \text { Psicologia geral-experimental } & 20,7 \\ \text { Psicologia médica } & 15,2 \\ \text { Tecnopsicologia } & 12,8 \\ \text { Educação física e psicologia esportiva } & 7,3 \\ \text { Personalidade, psicologia diferencial } & 5,9 \\ \text { Psicologia social } & 3,8 \\ \text { Psicofisiologia } & 2,2 \\ \text { História da psicologia } & 1,2 \\ \text { Relatos filosóico-teoréticos } & 1,0 \\ \text { Psicologia comparativa } & 0,7\end{array}$

Que dados são interessantes ou surpreendentes?

A estrutura difere do padrão da psicologia norte-americana. O campo de pesquisa mais amplo é o campo de psicologia da criança e de educação. Seguem a psicologia geral-experimental, médica e tecnológica. Surpreendentemente em alta freqüência de citações é o campo da educação física e psicologia esportiva.

5) Nosso estudo bibliométrico mais recente (Brožek e Hoskovec, 1995) tem a ver com a relação entre a psicologia tcheca e a literatura internacional. A primeira fonte de informação foram os trabalhos psicológicos escritos por Thomas Garrigue Masaryk (1850-1937) publicados no período de 1880-1900. Neste período Masaryk serviu como professor de filosofia na Universidade Tcheca de Praga.

\section{Controvérsias como recurso metodológico em história da psicologia}

Na Ciência idealizada, com o "C" grande, não há lugar para controvérsias. De fato, nas revistas de física, biologia ou fisiologia não há espaço institucionalizado para controvérsias. Nas "verdadeiras ciências", assim insiste o folclore, relatam-se dados, desenvolvem-se teorias, que serão aceitas quase sem debate. Na Psicologia, ao contrário, se examinamos um número do Contemporary Psychology, revista norte-americana de resenhas bibliográficas, encontramos uma seção intitulada "On the other hand" (Por outro lado...). 
A perseverança no sentido de ser apegado a uma abordagem ou a um ponto de vista é, de fato, um aspecto negativo do pensamento dirigido a soluções, mas a persistência, o esforço contínuo, é uma conduta essencial a todo empenho para resolver problemas. Muitos anos foram necessários para o desenvolvimento da teoria de relatividade de Einstein. Persistência é um ingrediente significativo para qualquer realização substancial.

Em particular na ciência norte-americana, as controvérsias não gozam de boa reputação. São vistas como uma injeção de emocionalismo no empreendimento racional que é a ciência. Alguns psicólogos, entre outros, Mary Henle, divergem sobre esse ponto. As questões podem ser significantes, não triviais, e não devem ser negligenciadas.

Mary Henle deu ênfase ao fato de que o significado de um termo ou de uma declaração depende do contexto em que ocorre. Não é raro que as controvérsias emerjam (e persistam) porque os dados provêm de diferentes contextos.

A verificação (replicação) é critério básico de trabalho na ciência.

Mesmo pequenas diferenças nas condições do experimento, tarefas, métodos e instruções dadas aos sujeitos experimentais podem ameaçar os resultados das observações, e geram controvérsias.

Mary Henle apontou aspectos e efeitos potencialmente positivos de controvérsias científicas:

1) uma controvérsia pode estimular pesquisa adicional, com melhor desenho de experimentos e com métodos melhores;

2) uma controvérsia pode contribuir para o esclarecimento da matéria em pesquisa e para uma formulação explícita das suposições implícitas.

Contudo, os efeitos das controvérsias podem ser também negativos:

1) os pontos de vista podem tornar-se rígidos;

2) algumas vezes, sob o impacto da crítica, as posições tornam-se mais extremas.

Por último, os modos de resolver controvérsias são: 
1) uma questão pode resolver-se na base de métodos novos. Às vezes este passo faz-se não pelos protagonistas originários, mas pela segunda ou terceira geração dos cientistas comprometidos com o problema;

2) o problema pode ser visto numa perspectiva menos radical em que as contradições dissolvem-se numa síntese mais abrangente. Por exemplo, a controvérsia entre psicólogos que consideram o meio ambiente ou os fatores genéticos como determinantes do comportamento pode resultar na elaboração de um modelo que inclua um terceiro fator, a atividade do organismo.

Estas reflexões podem ser consideradas como um capítulo da filosofia (mais precisamente, da epistemologia). Qual é o significado das controvérsias para a historiografia? A análise das controvérsias constitui um método para reconstruir a história da psicologia. Foi um historiador alemão J.L. Pongratz (de Wurzburg) quem preparou um grande livro baseado neste princípio (infelizmente, não encontrou uma editora que recebesse o texto).

Até agora, listamos todos os tópicos de interesse para o historiador da Psicologia? Certamente não. A Psicologia como disciplina científica e como profissão apresenta uma quantidade praticamente ilimitada de temas. É a seleção do tema que é de importância crítica.

Como fazê-la judiciosamente? Não há receita universalmente válida.

\section{Algumas “obras de consulta”}

WATSON, Robert I. (I, 1974; II, 1976).

Eminent Contributors to Psychology.

Vol. I, A Bibliography of Primary References. 470 pp.

Vol. II, A Bibliography of Secondary References. 1158 pp.

Uma análise e crítica detalhada ("Summa psychologiae: A special review") apareceu no Journal of the History of the Behavioral Sciences, 14, 74-83, 1978. O resumo termina como segue: "A bibliografia representa uma obra de consulta essencial. Servirá aos estudantes, professores e especialistas dentro e fora da psicologia”. 


\section{História da psicologia - um guia:}

VINEY W. Wertheimer, Michel, \& Wertheimer, Mariyn L. History of Psychology: A guide to information sources. Detroit, Michigan: Gale Research Co., 1979. 502 pp.

O livro tem 5 partes: a) Obras de consulta geral. b) Obras de consulta específica no campo da história da psicologia (obras sumárias [abstracts], livros de leitura [readings], psicologia nos diferentes países [nada a respeito do Brasil...], histórias especializadas (sociedades, revistas, instrumentos, mulheres). c) Sistemas e escolas. d) Áreas da psicologia. e) Áreas relacionadas.

\section{Dicionários e enciclopédias de Psicologia}

CORSINI, R.J. (Ed.) (1984; segunda edição, 1994). Encyclopedia of Psychology. 4 volumes; o quarto volume é dedicado à bibliografia. DUIJKER, H.C.J. \& Van Rijswijk (1975). Trilingual Psychological Dictionary. vol. 1, E-F-G; vol. 2, F-G-E; vol.3, G-E-F. Bern, Hans Huber (um vocabulário).

ENGLISH, H.B. \& English, Ava Champney, (Eds.) (1958). A Comprehensive Dictionary of Psychological and Psychoanalitic Terms: A Guide to usage. Nova York, Longmans, Green \& Co.

EYSENK, H.J., Arnold, W., \& Meilli, R. (1972). Encyclopedia of Psychology (in 3 vols.). Nova York, Herder. (mais um dicionário do que uma enciclopédia).

HEHLMANN, W. (1974). Worterbuch der Psychologie (com informações biográficas). Stuttgart, A. Kroener Verlag.

RITTER, J. \& Gruender, K. (vol. 1, A-C, 1971; vol. 8, R-Sc, 1992) Historisches Worterbuch der Philosophie. Basel, Schwabe Verlag. (uma obra enciclopédica).

ZUNE, L. (1975) Names in the History of Psychology: A Biographic Sourcebook. Nova York, John Wiley. 


\title{
Historiografia da Psicologia: métodos
}

\author{
Marina Massimi* \\ Regina Helena de Freitas Campos** \\ Josef Brožek ${ }^{* * *}$
}

O fato de que sob o rótulo de História da Psicologia compreendem-se dois domínios distintos - o da História da Psicologia Científica e o da História das Idéias Psicológicas - acarreta importantes implicações do ponto de vista metodológico. Com efeito, por um lado, a Historiografia das Idéias Psicológicas utiliza-se dos métodos próprios da História Cultural e da História Social, por outro lado, a Historiografia da Psicologia Científica assume as modalidades de investigação sugeridas pela Historiografia das Ciências.

Sumarizamos aqui os principais recursos metodológicos possíveis em cada um desses domínios.

\section{Os métodos da historiografia das idéias psicológicas}

Recentemente, os métodos da História das Idéias Psicológicas foram profundamente influenciados pelas mudanças ocorridas no âmbito da Historiografia Geral.

Com efeito, a revolução historiográfica ocorrida a partir dos anos 30 na França (Escola dos Annales) causou a emergência de novos objetos e novos métodos nessa área de conhecimento. Tornaram-se, assim, questões de interesse para o historiador temas como as atitudes humanas frente à vida e à morte, as crenças e os comportamentos religiosos, as relações familiares e sociais em geral, o que determinou "a constituição de novos territórios do historiador através da anexação dos territórios dos outros.” (Chartier, 1990, p. 14). De fato, tratava-se de campos já desvendados pelas Ciências Humanas, tais como a Sociologia, a Psicologia, a Antropologia,

\footnotetext{
* Programa de Pós-graduação, Universidade de São Paulo-Ribeirão Preto.

*** Programa de Pós-graduação, Universidade Federal de Minas Gerais.

*** Professor na Lehigh University, nos EUA.
} 
entre outras. Desse modo, a Historiografia começou a utilizar metodologias de investigação próprias a outras disciplinas próximas, abrindo-se, ao mesmo tempo, a projetos de pesquisa de caráter interdisciplinar acerca de seu objeto.

A revisão da produção historiográfica contemporânea (especialmente dos 15 anos entre 1978 e 1983) elaborada por Emmanuel Le Roy Ladurie em 1983 mostra a amplidão do campo de interesse do historiador contemporâneo; desde o estudo de diversas culturas e experiências religiosas, das festas e dos ritos, do mundo dos intelectuais e da cultura popular às diversas maneiras de viver, de habitar e de trabalhar.

Nesse sentido, conforme observa Philippe Ariès, "as margens entre a história e as outras ciências humanas começam a se atenuar.” (em Le Goff, 1993, p. 162). Novas áreas da pesquisa historiográfica constituem-se num terreno multidisciplinar, envolvendo inclusive enfoques de natureza psicológica: entre outras, a Antropologia Histórica, a História do Imaginário, a História das Mentalidades.

No seio desta nova perspectiva interdisciplinar, definem-se então formas originais de colaboração entre Psicologia e História e, no que mais diretamente diz respeito à História das Idéias Psicológicas, criam-se, neste domínio, abordagens inéditas para a leitura e a interpretação dos documentos.

Especificamente devemos ressaltar as contribuições dadas à Historiografia das Idéias Psicológicas pela História Cultural, pela Microhistória, pela História das Mentalidades.

\section{A história das idéias psicológicas como parte da história cultural}

A História Cultural, promovida pelos “novos historiadores” propõe uma nova maneira de entender a "História das Idéias". De fato, ao definir o campo da "História das Idéias”, a referência utilizada pelos historiadores não é mais aquela da tradicional História do Pensamento, de marco hegeliano - que visava a reconstrução histórica de conceitos e teorias elaborados exclusivamente pela intelectualidade -, mas a reformulação recente deste campo de estudos por L. Goldmann (1955), em termos de uma “história das visões do mundo”. Conforme afirma Roger Chartier (1990), 
a noção de visão do mundo permite articular, sem os reduzir um ao outro, o significado de um sistema ideológico descrito por si próprio, por um lado, e, por outro, as condições sociopolíticas, que fazem com que um grupo ou uma classe determinados, num dado momento histórico, partilhem, mais ou menos, conscientemente ou não, esse sistema ideológico. (p. 49)

Desse modo, recortando no âmbito deste domínio o setor relativo à História das Idéias Psicológicas, pode-se afirmar que esta se ocupa daqueles aspectos específicos da "visão do mundo" de uma determinada cultura, relacionados a conceitos e práticas que na atualidade podem ser genericamente entendidos como psicológicos. A definição do que é psicológico, nesse caso, deve permanecer necessariamente indeterminada e vaga, quase como denominação convencional e provisória a ser substituída no decorrer da pesquisa pela terminologia e demarcação de campo próprios aos específicos universos socioculturais estudados. Tratar-se-á, por exemplo, de estudar a "terapêutica moral” do século XIX, ou os "remédios para o ânimo” do século XV; ou as “paixões” do século XVI.

Em suma, a História das Idéias Psicológicas é uma reconstrução dos conhecimentos e das práticas psicológicas próprios de específicos contextos socioculturais do passado, seus objetos sendo considerados na perspectiva de uma História Cultural, a saber, como sendo relativos ao meio sociocultural em que são construídos.

A abordagem metodológica da História Cultural busca identificar, conforme afirma um dos seus mais famosos intérpretes, R. Chartier (1990), o "modo como em diferentes lugares e momentos, uma determinada realidade social é construída, pensada e dada a ler” (p. 17). O espaço cultural desta História é bidimensional, abrangendo a produção cultural na especificidade de um gênero ou disciplina em suas relações com a totalidade social em que se origina. De modo diferente do que ocorrera nas mais tradicionais Histórias do pensamento, os objetos desta não são dados naturalmente nem universalmente, sendo, conforme ensina Foucault ao ocupar-se da loucura, apenas “objetivações”. Portanto, adverte Chartier,

a história intelectual não deve cair na armadilha das palavras que podem dar a ilusão de que os vários campos de discursos ou de práticas são constituídos de uma vez por todas, delimitando objectos cujos contornos, ou mesmo os conteúdos, não variam; pelo contrário, deve estabelecer como centrais as descontinuidades que fazem com 
que se designem, se admitam e se avaliem, sob formas diferentes ou contraditórias, consoantes às épocas, os saberes e os actos. (p. 65).

A definição de “cultura” elaborada pelo antropólogo Clifford Geertz fornece um parâmetro significativo para a determinação do campo de História Cultural dada por Chartier:

o conceito de cultura denota um padrão, transmitido historicamente, de significados corporizados em símbolos, um sistema de concepções herdadas, expressas em formas simbólicas, por meio das quais os homens comunicam, perpetuam e desenvolvem o seu conhecimento e as atitudes perante a vida. (1973, p. 89, tradução nossa).

Nesse sentido, a História Cultural vale-se também da colaboração com a antropologia histórica, definida por Burguière como "história dos hábitos físicos, gestuais, alimentares, afetivos e mentais” (em Le Goff, 1993, p. 133). Para Marshall Sahlins (1990), o desenvolvimento da antropologia histórica faz "explodir o conceito de história pela experiência antropológica da cultura”. Deste modo, o domínio da História vem ocupar novos espaços:

A História, até há pouco tempo obscura, de ilhas remotas, merece o seu lugar ao lado da autocontemplação do passado europeu - ou da história das civilizações - por contribuições próprias e notáveis a uma compreensão histórica. Assim, multiplicamos nossos conceitos de história pelas diversidades de estruturas e assim, de repente, há um mundo de coisas novas a serem consideradas. (1990, p. 94)

A História Cultural conta também com a colaboração de outra subárea da Nova História, a saber, a História do Imaginário: esta estuda a influência das "imagens" na vida dos homens, ao longo do tempo. Não se trata, porém, apenas de imagens próprias da produção iconográfica, ou artística: conforme escreve Le Goff (1994), “englobam também o universo das imagens mentais" (p. 16). Para o historiador francês, "a história do imaginário é o aprofundamento dessa história da consciência cujo despertar na Idade Média o Padre Chenu analisou de modo tão esclarecedor” (idem). A consciência não é concebida, porém, como um fenômeno inerente à psiquê individual e sim como um "fenômeno coletivo, social e histórico." (ibidem). A importância deste enfoque na historiografia da cultura ocidental é apontada por Le Goff, ao afirmar que "estudar o imaginário de uma sociedade é ir ao fundo da sua consciência e da sua evolução histórica. É ir 
à origem e à natureza profunda do homem, criado à imagem de Deus.” (idem, p. 17). O surgimento desta consciência da natureza humana no século XII inspira a produção de todo um corpus de representações artísticas e iconográficas, que traduzem em signos exteriores as imagens profundas próprias do universo mental do Ocidente medieval. Nesse âmbito, então, a Psicologia e a Psicanálise auxiliam o trabalho de interpretação histórica deste tipo de documentação. Ao mesmo tempo, porém, muitos documentos objeto da História do Imaginário, tais como frontispícios de livros, mapas, tábuas, retratos e outros tipos de pinturas, podem auxiliar a reconstrução do passado no âmbito da História das Idéias Psicológicas.

Cabe por fim destacar, no âmbito da História Cultural, a contribuição de Michel Foucault (1992), cuja perspectiva histórica oferece uma interpretação original acerca da gênese das Ciências Humanas e, ao mesmo tempo, desvenda novos objetos para a Historiografia geral. As práticas sociais são consideradas por Foucault como a origem de formas novas de sujeitos e de domínios de conhecimento. Aponta-se, então, para a historicidade destes domínios.

\section{A microhistória e a história das idéias psicológicas}

Outro interessante enfoque, conseqüência da revolução historiográfica realizada pela "Nova História”, é a assim chamada “Microhistória”, representada, entre outros, por Carlo Ginsburg. Num artigo recente (1994), Ginsburg define de forma clara os fatores principais desta abordagem: em primeiro lugar, a recusa do etnocentrismo e da visão teleológica da história, próprios da historiografia do século XIX, em favor do interesse pelos indivíduos concretos e pelas características peculiares da documentação encontrada (qualquer documento, mesmo o mais anômalo, pode iluminar o trabalho da reconstrução histórica). Trata-se, conforme a expressão de Ginsburg (1994), de “reduzir a escala de observação” (p. 522) dos fatos, pois o "olhar de perto" possibilita a apercepção de algo que, de outro modo, escaparia à visão do conjunto (“macrohistória”). Tal prescrição metodológica baseia-se numa afirmação ontológica acerca da descontinuidade e da heterogeneidade da realidade. Isto explica também a adesão ao modelo construtivista, baseado no postulado de que o objeto da pesquisa histórica é construído, não dado. A ênfase no estudo do indivíduo 
no contexto social, ou, mais propriamente, das "relações interpessoais" (Grendi, 1994, p. 540), enquanto sujeitos do processo histórico, permite, por meio da "reconstrução da experiência vivenciada" (Revel, 1994, p. 556) pelo sujeito, proporcionar uma modalidade de abordar e compreender o processo social global por intermédio do estudo do destino individual. Para isso, é preciso que, paralelamente à análise dos “comportamentos”, sejam evidenciados os "contextos" nos quais esses se inscrevem. "O que a experiência de um indivíduo, de um grupo, de um espaço, permite detectar é uma modulação particular da história global”, escreve Revel (p. 561).

Esta abordagem tem sido recentemente aplicada também ao estudo de temas próprios à História das Idéias Psicológicas. Roy Porter (1989), por exemplo, discute o estruturar-se do conceito de alienação mental e a distinção entre racionalidade e loucura, na época da Revolução Francesa, por meio da reconstrução de uma história particular, a do mercador James Tylli Matthews e do psiquiatra John Haslam, que diagnosticou e "tratou” da "loucura" de Matthews.

\section{A psicologia histórica, a história das mentalidades e a história das idéias psicológicas}

A afirmação do caráter essencial de historicidade da experiência humana, inclusive em sua dimensão psicológica, caracteriza a abordagem da Psicologia Histórica, proposta por Ignace Meyerson (1888-1983). O postulado da relatividade histórica da Psicologia humana subordina a Psicologia à História, enfatizando, portanto, a relevância cultural da Historiografia das Idéias Psicológicas, enquanto documentação da relatividade histórica de conhecimentos e práticas psicológicas, ao longo do tempo.

A tese central da Psicologia Histórica, exposta por Meyerson em sua obra Les fonctions psychologiques et les oeuvres (Paris, 1948), é a de que

a análise do comportamento através dos fatos históricos modifica a perspectiva do psicólogo. Ele nada tem a fazer com o homem abstrato, mas com o homem de um país e de uma época, engajado no seu contexto social e material, visto através de outros homens igualmente de um país e de uma época. (em Penna, 1987, p. 25). 
Nesse sentido, questiona-se a legitimidade de uma Psicologia geral do homem entendida como conhecimento de leis universais da mente ou do comportamento humano, sendo, pelo contrário, necessário contextualizar a indagação acerca do homem psíquico, no âmbito histórico sociocultural de sua existência concreta. Meyerson, portanto, propõe uma psicologia pluralista, partindo da constatação de que, em todos os tempos e em todas as culturas, o homem tem se interrogado acerca de si mesmo; ao longo da história tal interrogação assumindo, porém, formas diferentes (Leroy, 1986). O que implica uma ruptura com relação às posições universalistas da Psicologia Clínica, da Psicologia Fisiológica, da Psicologia Experimental tradicionais, e uma redefinição em termos históricos dos conceitos utilizados por elas. Objetos como as "cores", a "pessoa", o "tempo", o "espaço", o "trabalho", a "linguagem" e os "sinais" são assim revisitados pela Psicologia Histórica, conforme documentam as atividades desenvolvidas pelo "Centre de Recherches de Psychologie Comparative" dirigido por Meyerson, ao longo de mais de 30 anos de vida (desde 1950 até 1986) (Leroy, 1986).

A partir dos anos 60, consolidou-se novo setor dos estudos históricos, chamado "História das Mentalidades", particularmente próximo à Psicologia Histórica, mas percorrido principalmente pelos historiadores, e não pelos psicólogos. Nesse enfoque, os comportamentos e as crenças da vida cotidiana de uma sociedade revelaram-se significativos de um sistema de representação do mundo profundamente vinculado com as formulações intelectuais mais elaboradas (concepções religiosas ou filosóficas, sistemas científicos, etc.).

O conceito de mentalidade, introduzido por Lucien Febvre em 1939, era "suficientemente incerto e suficientemente aberto para digerir a contribuição das outras disciplinas”. (Burguière, em Le Goff, 1993, p. 148). Na perspectiva de Febvre, o estudo da História das Mentalidades demonstra a existência de atitudes mentais relativas a determinadas épocas históricas: assim, por exemplo, certas coisas que eram concebíveis e aceitáveis num determinado período, deixam de sê-lo em outra época e em outra cultura. Trata-se de atitudes diante da morte, da doença, do corpo, da vida, da idade, etc. Desse modo "questões capitais surgiam (...) requerendo explicações psicológicas e antropológicas outrora reservadas a médicos, moralistas, juristas, ou que pareciam pertencer ao domínio do não escrito em que os 
historiadores ainda nunca haviam tido a idéia de penetrar". (Ariès, em Le Goff, 1993, pp. 159-160).

Na definição de J. Le Goff, “o nível da história das mentalidades é o do cotidiano e do automático, é aquilo que escapa aos sujeitos individuais da história porque revelador do conteúdo impessoal de seu pensamento" (em Chartier, 1990, p. 41). Mais abrangente é a definição dada por R. Mandrou: a mentalidade é o que "é concebido, e sentido, o campo da inteligência e do afectivo" (idem). Comenta Chartier:

Daí, a atenção prestada às categorias psicológicas, tanto como (e mais, sem dúvida) às categorias intelectuais, e portanto um distanciamento suplementar entre uma história das mentalidades assim identificada com a psicologia histórica, e a história intelectual na sua definição tradicional (...). Assim, (...) são as categorias psicológicas essenciais - as que funcionam na construção do tempo e do espaço, na produção do imaginário, na percepção coletiva das actividades humanas - que são postas no centro da observação e apreendidas no que têm de diferente consoante às épocas históricas. (1990, p. 42)

Philippe Ariès define o método da História das Mentalidades em termos de compreensão das diferenças: existe

a percepção de uma diferença entre duas mentalidades, uma, que se supõe conhecida, que serve de "testemunha" e à qual o historiador se refere; a outra, enigmática, discutível, terra incógnita que o historiador se propõe a descobrir. Nesse caso, porém, descobrir é primeiro compreender uma diferença. (idem, p. 171).

Esta “diferença” separa outra cultura da nossa e assegura-lhe uma originalidade. Portanto, toda curiosidade histórica e toda percepção das diferenças têm como ponto de origem nossa mentalidade contemporânea. Talvez, a crise atual da modernidade contribua para aumentar o fascínio pela alteridade que o passado encerra em si.

Um exemplo significativo da metodologia utilizada pela História das Mentalidades, ao abordar o estudo das "idéias psicológicas" do homem de outras épocas e culturas, é o trabalho de Aaron Gourevitch (1993) acerca das categorias de "individualidade” e de "personalidade”, na Idade Média. Antes de mais nada, Gourevitch estabelece uma diferença entre o conceito de "personalidade" e o de "individualidade": a personalidade é uma 
construção social e cultural, adquirida por meio da interiorização da visão do mundo de um determinado grupo social; enquanto que a individualidade é um eu capaz de reconhecer a si mesmo como sujeito específico e peculiar. A seguir, ele demonstra que, na maioria dos casos, os historiadores referemse à subjetividade medieval fazendo uma confusão entre os dois termos, por exemplo, interpretando “topoi” e expressões retóricas utilizadas pelos escritores medievais, inerentes à personalidade, como sinais da individualidade. Por outro lado, Gourevitch aponta que a personalidade medieval deve ser estudada a partir de referenciais característicos do universo sociocultural da época, não podendo, portanto, serem utilizados modelos interpretativos próprios da Psicologia moderna e da Psicanálise. De modo semelhante, o processo de tomada de consciência de si mesmo do homem medieval dificilmente pode ser apreendido pelo historiador e, de qualquer forma, é muito diferente da modalidade em que o homem de hoje vivencia este mesmo processo. Assim, por exemplo, Gourevitch, ao analisar a obra do místico medieval Opicinus de Canistris, evidencia que as expressões da autoconsciência de si mesmo presentes no texto podem aparecer ao leitor moderno como sintomas de loucura!

\section{Um esclarecimento: a diferença entre a psicologia histórica e a psicohistória}

Apesar da semelhança terminológica, a Psicologia Histórica diferencia-se profundamente da Psicohistória: esta abordagem, inspirandose em algumas tentativas de análises de material histórico elaboradas por Freud - mais propriamente como ensaios literários do que como indagações científicas (é o caso dos estudos sobre Leonardo da Vinci e Moisés e o Monoteísmo, em: Freud, 1969a e b) -, propõe-se a explicar os fenômenos históricos em termos de categorias mentais universais, subordinando então a História à Psicologia ou à Psicanálise. Em suma, trata-se de analisar as motivações dos agentes de processos históricos em termos psicológicos ou, conforme afirma Lloyd De Mause (1981), trata-se de uma "ciência da motivação histórica” (p. 179), considerando-se os fenômenos políticos, sociais e econômicos como produtos da psicodinâmica humana (Ebel, 1989). O método da Psicohistória é a identificação dos “atores” do drama histórico e a análise, por meio da compreensão dos documentos, das motivações inconscientes dos processos históricos. 
A crítica freqüentemente feita a esta abordagem pela Historiografia geral, a partir das observações de L. Febvre, é a de ser reducionista e presentista, pois considera o homem do passado nos moldes de uma Psicologia do século XX.

É possível - questionava Febvre - que o historiador utilize a psicologia produzida pela observação do homem do século XX, para interpretar as ações do homem do passado? (Bizière, 1983, p. 92)

Pode ocorrer, além do mais, um uso anacronístico dos termos, de forma que palavras que denotam hoje determinados sentimentos ou idéias, assumam para nós estes mesmos significados quando encontradas em documentos do passado. Na realidade, ao longo do tempo, os significados dos termos utilizados para definir as experiências psicológicas podem mudar.

\section{Os métodos da historiografia da psicologia científica}

No que diz respeito à História da Psicologia científica, em sentido próprio, ela vem sendo considerada hoje como parte do domínio da História das Ciências. Como tal, utiliza os métodos e as abordagens por esta elaborados, informados pela Filosofia da Ciência.

\section{A contribuição da filosofia da ciência}

Popper (1993) ensinava que o conhecimento científico é sempre provisório. O jogo da ciência seria exatamente buscar a falsificação das teorias. As hipóteses seriam válidas somente enquanto não fossem falsificadas, ou enquanto não fossem substituídas por novas hipóteses, melhor formuladas. Neste modelo, a tarefa do historiador seria buscar os momentos em que determinadas teorias foram falsificadas ou, pelo contrário, não tendo sido falsificadas, foram consideradas confirmadas.

Kuhn (1975), entretanto, pensava a evolução da ciência por meio de revoluções. As interpretações hegemônicas em um dado período histórico seriam substituídas por um novo modelo de explicação, em um processo brusco de ruptura, quando o acúmulo de anomalias (eventos ou hipóteses que contradizem o modelo dominante) evidenciasse a sua inadequação. A esses modelos de interpretação Kuhn deu o nome de paradigmas, definindoos como uma forma de pensamento que contém elementos explícitos e 
implícitos, e que guia o raciocínio de uma dada comunidade científica durante um certo período. A ocorrência dessas rupturas, ou revoluções, questionava a idéia de que a ciência procede por uma progressiva acumulação de conhecimentos. A imagem mais adequada, segundo Kuhn, seria a de um processo de rupturas que repentinamente modificam o modo de pensar, as heurísticas e os estilos de interpretação então predominantes. A descrição do desenvolvimento científico proposta por Kuhn dá lugar para se pensar a existência de modelos de interpretação divergentes, ou mesmo antagônicos, competindo para se impor por meio de um conjunto de evidências. Neste caso, o historiador da ciência buscaria esses momentos bruscos de ruptura e a emergência de novos paradigmas.

Lakatos (1989), por sua vez, critica Kuhn por não haver dado uma explicação racional para a ocorrência das crises e rupturas no desenvolvimento científico. As anomalias estariam presentes mesmo em períodos de "ciência normal”, isto é, de produção cumulativa. O que provocaria a súbita irrupção de uma crise e de uma mudança de paradigma. Os paradigmas sucessivos, por outro lado, seriam incomensuráveis, ou seja, não existiriam critérios racionais para compará-los. Seria, pois, inteiramente aleatória (ou irracional, para Lakatos) a emergência de novos paradigmas.

Lakatos propõe um modelo um pouco diferente para a evolução e progressiva substituição das teorias científicas. A idéia é que, em cada domínio do conhecimento, teorias rivais estão em constante competição pela hegemonia. Cada teoria teria momentos de mudança progressiva, ou de mudança regressiva, conforme seu sucesso (ou não) na explicação dos fenômenos que se propõe a estudar. O trabalho do historiador da ciência, neste caso, seria buscar os debates entre programas de investigação rivais e analisar os motivos que levariam à hegemonia de um conjunto de hipóteses, a partir dos debates entre eles.

Muitos historiadores da Psicologia buscam encontrar a origem das teorias na própria evolução do pensamento científico. É quando, por exemplo, atribuem-se os progressos da Psicologia às descobertas da Biologia, ou ao uso do método experimental. Contudo, esta é uma explicação que trabalha com a hipótese de que o que determina o progresso científico é a acumulação de conhecimentos. Se, para Kuhn ou Lakatos, não se trata de acumulações, mas de rupturas, e nem sempre são os critérios 
racionais que engendram estas últimas, como explicar a emergência de paradigmas divergentes e sua permanência?

É neste ponto que se costuma recorrer a explicações externalistas.

Aliás, é o próprio Lakatos que lembra essa distinção fundamental entre a explicação internalista e a externalista. Para ele, assim como para Popper, o mundo científico se dividiria em três: o mundo da matéria, o mundo da consciência e o mundo das proposições, ou do conhecimento objetivo. O mundo das proposições requer a reconstrução racional. Os outros dois mundos, da matéria e da consciência, estariam sujeitos à dinâmica das influências externas ao fazer científico, isto é, aos fatores sociopsicológicos e, mais amplamente, aos movimentos da sociedade e da cultura. Embora considere a história interna a mais importante, é o mesmo Lakatos quem lembra:

Ninguna teoría de la racionalidad podrá explicar nunca la desaparición de la genética mendeliana de la Rusia soviética en la década de 1950, o las razones por las que algunas escuelas de investigación sobre diferencias raciales genéticas o sobre la economía de la ayuda exterior, quedaran desacreditadas en los países anglosajones en la década de 1960. (1989, p. 149)

No caso da Psicologia Científica, cujas hipóteses básicas derivam de observações do senso comum, e cujo desenvolvimento está estreitamente vinculado a demandas sociais e institucionais, as abordagens internalista e externalista são freqüentemente combinadas.

\section{História da psicologia e história das ciências}

A História das Ciências tem como pressuposto a afirmação da historicidade das mesmas: responde, portanto, à exigência de compreender a identidade conceitual e metodológica de uma determinada disciplina científica em seu contexto dinâmico. Seus objetivos específicos são os de entender a construção histórica de conceitos e métodos científicos; estudar as condições econômicas e sociais que presidiram a emergência dos ditos métodos e conceitos; interpretar o desenvolvimento científico em termos de uma determinada teoria da história, por um lado, e de uma específica definição de ciência, por outro. Embora a disciplina "História das Ciências" seja bastante antiga, sendo possível encontrar suas origens remotas no 
programa baconiano de "História da Cultura" e posteriormente no projeto para o ensino no Collège de France, formulado por Auguste Comte em 1832, apenas recentemente adquiriu status acadêmico respeitável. Afirma A.G. Debus (1991) que

até praticamente meados deste século, pensava-se que a História das Ciências era uma disciplina adequada principalmente para os cientistas que se voltavam para o escudo de suas especialidades no final de sua carreira, quando seus dias de pesquisa científica ativa haviam terminado. (p. 3)

Pela sua própria natureza de disciplina histórica, tendo por objeto diversas áreas da cultura científica, a História das Ciências tem um caráter interdisciplinar. De fato, se considerarmos a produção recente no campo, pode-se concordar com Debus acerca do fato de que

as forças e as interpretações desafiando os historiadores da ciência nas últimas três décadas refletem muitos dos problemas recorrentes a todos os historiadores neste mesmo período. (p. 3)

Esta relação tornou-se explícita e fecunda só recentemente, pois, no passado, as relações entre a História das Ciências e a História não foram suficientemente desenvolvidas pelos primeiros historiadores das ciências.*

Por outro lado, a História das Ciências tem desenvolvido metodologias próprias para a análise do desenvolvimento histórico das diversas disciplinas científicas, sob a influência da Epistemologia. Esta, tendo função prescritiva acerca da identidade de uma ciência determinada (pelo fato de propor critérios de demarcação entre o que é a ciência e outros tipos de conhecimentos), inevitavelmente condiciona a História,

\footnotetext{
* Um aspecto da fecundidade desta interação é apontado por Jacques Roger (1993), que aplica o conceito de mentalidades - formulado no âmbito da historiografia geral - à História das Ciências, definindo a mentalidade como um conjunto de atirudes coletivas. Assim, pode-se aplicar esta categoria à História das Ciências em dois níveis: em primeiro lugar, como escudo das relações de convergência e oposição entre a mentalidade da cultura popular e a mentalidade da elite científica; em segundo lugar, como estudo da mentalidade cientifica, ou seja, das atitudes que, no âmbito de uma determinada comunidade científica, tornaram-se inconscientes, "espontâneas” inquestionáveis. Para dar um exemplo, a comunidade científica do século XIX apresenta várias destas atitudes: a fé num progresso infinito e necessário, a sacralização da ciência, a hostilidade com relação a toda forma de pensamento e de experiência religiosos, o reducionismo, o dogma da desigualdade entre as raças humanas. Desse modo, a mentalidade científica torna-se um produto fossilizado da história intelectual, desaparecendo toda justificativa racional.
} 
fornecendo-lhe parâmetros para delimitar o objeto de suas análises. Assim sendo, existem atualmente diversas abordagens metodológicas em História das Ciências, tais como o paradigma indutivista, herança de uma visão positivista da ciência e de seu progresso; o paradigma historicista derivado do marxismo; o paradigma convencionalista e o racionalista, ambos herdeiros da filosofia kantiana e hegeliana; o paradigma internalista, que se ocupa da dinâmica evolutiva interna do pensamento científico, e o externalista que, pelo contrário, busca compreender as mudanças científicas a partir do contexto social; o paradigma kuhmano das "revoluções científicas” (descontinuísta) e o paradigma continuísta de P. Duhem, que estabelecem relações profundas entre a história do pensamento científico e a tradição cultural mais antiga, objeto da História das Idéias.

Evidentemente, estas propostas metodológicas influenciam a Historiografia da Psicologia. Se os primeiros psicólogos-historiadores inspiravam-se no modelo historiográfico positivista, já há exemplos da introdução de outras abordagens no âmbito dos estudos históricos em Psicologia.

A "bíblia” da historiografia da psicologia moderna, o livro Historiography of Modern Psychology (1980) de Brožek e Pongratz, por exemplo, descreve cinco abordagens possíveis nesta área de estudos: 1) a abordagem biográfica, baseada na reconstrução da história de vida dos cientistas; 2) a abordagem descritiva e analítica, baseada na reconstrução dos acontecimentos históricos a partir do levantamento de fontes primárias e na busca da compreensão de cada elemento do fato histórico no seio de seu contexto de produção; 3) a abordagem quantitativa, que aplica a análise historiométrica à literatura psicológica; 4) a abordagem da história social, enfatizando a primazia dos fatores sociais para explicar a evolução da psicologia científica; 5) o enfoque sociopsicológico, que busca combinar a primeira e a quarta abordagens.

\section{Os métodos historiográficos quantitativos}

Os estudos quantitativos realizados por Brožek (1980) apontam para a fecundidade heurística desta metodologia: por exemplo, o estudo da "longevidade da citação" pode ser utilizado como critério para reconstruir a importância histórica de uma obra. Tal enfoque foi aplicado, entre outros, na pesquisa acerca de um artigo do fisiólogo holandês F.C. Donders, 
publicado no ano de 1868: foram estudadas as citações deste artigo ao longo de cem anos, verificando-se que o número de citações aumentara na década entre 1940 e 1950 (Brožek, 1970).

Um trabalho já bastante conhecido realizado por meio de uma abordagem quantitativa é a pesquisa sobre Wundt no contexto da Psicologia americana, realizada por Brožek (1980): o objetivo era a caracterização quantitativa das mudanças no tempo da freqüência das citações de Wundt em 90 volumes (1887-1977) de uma revista científica norte-americana, o American Journal of Psychology, o mais antigo periódico americano de Psicologia científica. Os resultados indicavam com clareza o declínio do impacto de Wundt sobre a psicologia norte-americana, sendo que a freqüência das citações dos trabalhos de Wundt decresce dos primeiros 30 volumes da revistas (72,3\%) para os últimos 30 volumes $(7,7 \%)$.

Os métodos quantitativos revelam-se muito fecundos também como instrumentos para avaliar o interesse pelas teorias psicológicas relativo ao clima sociocultural de um determinado período histórico.

As traduções de livros de Psicologia num determinado país podem ser consideradas, por exemplo, como indicadores de seu clima político e cultural do mesmo país. Um trabalho neste sentido foi desenvolvido por Brožek no que diz respeito à Iugoslávia no pós-guerra, na época do regime de Tito. As primeiras traduções foram traduções de livros russos, mas, em meados dos anos 50, apareceram algumas traduções de obras francesas e alemãs. A partir de 1960, a literatura americana tornara-se dominante (Brožek, 1972).

Para reconstruir a estrutura da Psicologia soviética nos anos 60, Brožek (1969) analisou do ponto de vista quantitativo os conteúdos das Atas da Terceira Reunião da Sociedade Soviética de Psicologia, em 1968, especificando o número das contribuições apresentadas referentes às diversas áreas da Psicologia. Os resultados apontam para a relevância da Psicologia da Criança e da Educação no contexto soviético (29,2\% das contribuições foram apresentadas nesta área).

Um estudo bibliométrico mais recente (1994) refere-se às relações entre a Psicologia Tcheca e o contexto internacional, por meio da análise quantitativa das citações contidas nos trabalhos do psicólogo T.G. Masaryk (1850-1937), publicados no período entre 1880 e 1900, citações referentes à 
literatura psicológica em diversos idiomas. As citações dos trabalhos psicológicos demonstram uma interação ativa com a literatura mundial. Especificamente, além de publicações tchecas, entre 163 obras psicológicas citadas por T.G. Masaryk, 42\% foram em língua alemã, 26\% em francês e $32 \%$ em inglês.

\section{A historiografia internalista}

Os trabalhos que se utilizam desta abordagem metodológica enfatizam a análise da lógica interna da produção intelectual, focalizando a evolução científica a partir das contribuições originais dos autores ou analisando a lógica que preside a elaboração de conceitos relevantes para a História da Psicologia. Neste segundo sentido, tal perspectiva pode ser definida também como História Conceitual.

A abordagem historiográfica denominada por Pongratz (1980) como “descritivo-analítica” e a leitura da História da Psicologia em termos de tentativas de solução de controvérsias teóricas podem ser consideradas aplicações deste enfoque.

O “internalismo" é uma leitura historiográfica sem dúvida muito fecunda, sobretudo ao evidenciar os problemas teóricos fundamentais da psicologia moderna e ao proporcionar uma leitura epistemológica da evolução histórica da Psicologia, como demonstram os estudos desenvolvidos neste âmbito, por exemplo, o livro Antinomie epistemologiche nella psicologia contemporanea (1977) de S. Marhaba. Um exemplo clássico, nesse sentido, é o estudo de R. Watson sobre a Psicologia como "Ciência Prescritiva” (1967), as prescrições sendo orientações gerais que guiam a pesquisa psicológica. Estas teriam uma precisa conotação histórica e articular-se-iam, em muitos casos, em duplas contrastantes.

Trabalhos mais recentes, ao proporem a análise histórica de alguns conceitos, oferecem exemplos de histórias conceituais, numa perspectiva internalista: seriam eles, a História da histeria (1991) de E. Trillat; a Préhistória do condicionamento (1976) e A loucura e as épocas (1994) de I. Pessotti; a investigação sobre as origens históricas do conceito de neurose de López Piñero (1983); o artigo de S. Diamond (1973) sobre as origens do 
conceito de instinto; o trabalho de Ch. Cofer (1981) sobre a história do conceito de motivação e o de S. Jackson (1983) sobre a melancolia.

\section{A historiografia externalista}

A introdução da abordagem externalista na historiografia da Psicologia realiza-se por meio da influência da "História Social das Idéias"; em particular, o trabalho de M.G. Ash (1987) sobre as relações entre Psicologia e Política em Viena, no período entre as duas guerras mundiais, bem como o livro de R.C. Fuller (1982) sobre o mesmerismo e a terapia do $e u$, nos Estados Unidos, e a obra de Mintz e Kellogg (1987) dedicada à História Social da família americana são representativos deste tipo de análise historiográfica. Outros exemplos recentes de abordagem externalista são o artigo de D. Leary (1987) sobre a institucionalização da “Nova Psicologia” nos Estados Unidos e o ensaio de I. Nicholson (1994) acerca das relações entre a "Nova Psicologia" e o Protestantismo americano. O manual de História da Psicologia organizado por M.G. Ash e W. Woodward (1987) reflete a mesma orientação.

As contribuições de K. Danzinger (1979a e b, 1984, 1989, 1990a e b) traçam um itinerário por ele mesmo definido como "História Crítica da Psicologia”, em que o processo histórico é considerado como o produto da interação dinâmica entre os atores humanos e o contexto social.

O texto Psicologia: tra ideologia e scienza (1974) do autor italiano Dario Romano propõe uma perspectiva histórico-crítica na abordagem do estudo de conceitos utilizados pela Psicologia moderna, tais como a percepção, o eu, o inconsciente.

Todos estes trabalhos, em suma, procuram evidenciar as relações entre o desenvolvimento da Psicologia e o contexto sociocultural e político onde esta é produzida, ensinada e praticada. Procura-se esclarecer também como um determinado contexto interfere nos pressupostos adotados pelas escolas psicológicas e na própria elaboração dos conceitos por estas elaborados (Leahy, 1987).

Trata-se de uma orientação adotada por muitos historiadores da psicologia contemporâneos. Conforme enfatiza Campos (1996), 
a psicologia é uma ciência que utiliza, na elaboração de suas teorias, conceitos retirados do senso comum, da vida cotidiana em uma determinada sociedade. Por outro lado, o pesquisador em psicologia participa da sociedade em que vive, e tem opiniões definidas em relação a muitas das questões que estuda, e que afetam sua vida como cidadão. As instituições onde trabalham os pesquisadores também interferem na sua produção teórica, na medida em que buscam incentivar estudos em determinada área mais do que em outra. Assim, o estudo da história da psicologia no contexto sócio-cultural e institucional, e dos efeitos deste contexto no desenvolvimento da disciplina, vem ganhando mais espaço. A idéia de que a atividade de produção do conhecimento científico é um empreendimento social fortemente influenciado pelas ideologias e forças sócio-políticas que o tornam possível fica cada vez mais presente. (p. 14)

Um dos fatores que contribuiu de modo significativo para que os historiadores da psicologia assumissem esta ótica é o clima de crítica social que marcou as décadas de 60 e 70 . Um dos efeitos desta crítica foi o desvelamento das relações entre teorias e práticas psicológicas e poder dominante, relações que marcaram, entre outras, a atuação de muitos profissionais das ciências do comportamento ao longo do século XX.

Um dos expoentes mais importantes da abordagem externalista na Historiografia da Psicologia, o já citado M.G. Ash (1987), aponta para algumas orientações emergentes neste âmbito: a tendência a interpretar os acontecimentos "internos” na pesquisa em termos do contexto "externo" no qual ocorrem; o estabelecimento de relações entre o pensamento e a prática dos psicólogos e o sistema de crenças e valores ao qual estes aderem; o impacto da política e das ideologias na evolução das idéias e das práticas psicológicas. Desse modo, a História da Psicologia transforma-se num capítulo da História Social.

\section{A discussão acerca da perspectiva descontinuísta versus a perspectiva continuísta, na historiografia da psicologia}

A proposta historiográfica de Th. Kuhn (A Estrutura das Revoluções Científicas, 1962; 1975 ed. bras.) introduziu na historiografia da Psicologia a discussão acerca da possível existência de descontinuidades e rupturas na evolução histórica da área. Existiriam "revoluções científicas” no âmbito da História da Psicologia científica? Ou a Psicologia teria evoluído de uma 
forma continuísta? (Buss, 1978; Lipsey, 1974, Palermo, 1971; Suppe, 1984).

Nesse sentido, cabe citar os questionamentos propostos por Roger Smith (1988) e por K. Danzinger (1990b) acerca da ausência de um objeto único e de uma terminologia unívoca na História da Psicologia. Com efeito, não existiria, para Smith, uma História da Psicologia e sim diversas "Psicologias" com desenvolvimentos históricos peculiares. Da mesma forma, Danzinger enfatiza que termos psicológicos tais como sensação, percepção, motivação, estimulação, etc. assumiram significações diferentes em diversos períodos históricos.

Tratar-se-ia então de uma descontinuidade profundamente enraizada no pensamento psicológico, e visível ao longo da história.

Numa perspectiva continuísta, pelo contrário, o saber psicológico desenvolver-se-ia de modo linear e cumulativo, não havendo cortes entre História da Psicologia Científica e História das Idéias Psicológicas. Muitos autores que formularam conhecimentos psicológicos no passado longínquo seriam então considerados como precursores de teorias mais recentes.

Na realidade, cada uma das duas perspectivas trouxe contribuições importantes à Historiografia da Psicologia, do ponto de vista metodológico. Se o descontinuísmo alertara para a necessidade de considerar o reconhecimento da diversidade como elemento fundamental do trabalho historiográfico, por outro lado, o continuísmo valorizara formas de conhecimentos que, elaborados num passado longínquo, ainda conservam um valor heurístico atual.

\section{O pluralismo metodológico}

Em suma, a relação entre a Historiografia da Psicologia e a Historiografia das Ciências proporciona à primeira uma plural idade de modelos e métodos. Em muitos casos, um enfoque "multifásico" e funcional ao específico problema abordado é utilizado pelos historiadores.

Cabe ao historiador da Psicologia, conforme afirmam Hilgard, Leary e McGuire (1991), a escolha dos métodos mais apropriados para a indagação historiográfica acerca de um determinado tema, num determinado período de tempo, num dado contexto, no âmbito de sua área 
de estudos. O método não deve ditar os tópicos da pesquisa. A peculiaridade do objeto da Psicologia e a ambigüidade do status epistêmico da mesma ao longo da História comportam exigências específicas que se impõem a qualquer pesquisador que pretenda elaborar um projeto de investigação na área.

Por fim, gostaríamos de frisar que componentes essenciais do método historiográfico são a curiosidade, as perguntas, os interesses culturais e sociais de cada historiador. Se, conforme escreve Ariès (1989), "a história se concebe como um diálogo onde o presente não está nunca ausente,” a reconstrução histórica então é "não apenas uma técnica de especialista, mas uma maneira de ser no tempo do homem moderno” (p. 246).

\section{Referências}

ARIÈS, PH. (1989). O Tempo da História, Rio de Janeiro, Alves.

ASH, M.G. (1987). "Psychology and policies in interwar Vienna: the Vienna Psychological Institute, 1922-1942.” In: ASH, M.G., WOODWARD, W. R. (org.), Psychology in Twentieth-Century Thought and Society, New York, Cambridge University Press, pp. 143-64.

ASH, M.G. \& WOODWARD W.R. (Eds.) (1987). Psychology in Twentieth-Century Thought and Society, Cambridge e New York, Cambridge University Press.

BROŽEK, J. (1969). “Spectrum of Soviet psychology: 1968 model”. In: American Psychologist, 24, pp. 944-946.

. (1970). "Citation longevity and the timing of mental operations. Proceedings of the 78th Annual Convention”. In: American Psychological Publications, pp. 787-788.

. (1972). "Quantitative explorations in the history of psychology in Yugoslavia: Translations”. In: Psychological Reports, 31, pp. 397398.

BROŽEK, J. \& PONGRATZ, L.J.,(org.) (1980). Historiography of Modern Psychology, Toronto, Hogrefe.

(1980). "Quantitative approach: Wundt in America”. In: BROŽEK, J. \& PONGRATZ, J.L., (org.), Historiography of Modern Psychology, Toronto, Hogrefe, pp. 290-301. 
BUSS, A.R. (1978). "The structure of psychological revolutions". In: Journal of the History of the Behavioral Sciences, 14, pp. 57-54.

CAMPOS, R. \& H.F. (1996). Reconstrução da história da Psicologia educacional: relações entre a Escola de Genebra e os movimentos sociais de defesa dos direitos humanos, mimeo, Universidade Federal de Minas Gerais, Faculdade de Filosofia e Ciências Humanas.

CHARTIER, R. (1990). A História Cultural. Entre prática e representações, 1982, Lisboa, Difel.

COFER, CH.N. (1981). "The history of the concept of motivation". In: Journal of the History of the Behavioral Sciences, vol. 17, pp. 48-53.

DANZINGER, K. (1979a). "The positivist repudiation of Wundt". In: Journal of the History of the Behavioral Sciences, vol. 15, pp. 205230.

. (1979b). "The social origins of modern psychology.” In: BUSS, A.R., Psychology in Social Context, New York, Irvington, pp. 27-45.

. (1984). "Toward a critical historiography of psychology". In: Revista de Historia de la Psicología, vol. 5, pp. 99-108.

. (1989). Textbook history and the problem of historical continuity, 50th Annual Meeting. Canadian. Psychology. Association, Halifax, 8-9 de junho.

. (1990a). Constructing the Subject: Historical Origins of Psychological Research, New York, Cambridge Univ. Press.

. (1990b). "Generative metaphor and the history of psychological discourse.” In: LEARY, D.E., (org.), Metaphors in the History of Psychology, New York, Cambridge Univ. Press, pp. 331-356.

DEBUS, A.,G. (1991). "A ciência e as humanidades: a função renovadora da indagação histórica”. In: Revista da Sociedade Brasileira de História da Ciência, vol. 5, pp. 3-13.

DIAMOND, S. (1973). "Gestation of the Instinct Concept." In: SULLIVAN, J.J., JAYNES, J. \& HENLE M., Historical conceptions of Psychology, New York, Springer, pp. 150-165.

EBEL, H. (1989). "The Past, the Present and the Future of Psychohistory". In: The Journal of the Psychohistory, pp. 291-309.

FULLER, R.C. (1982). Mesmerism and the Cure of American Souls. Philadelphia, Univ. Penn. Press.

GINSBURG, C. (1994). "Sulla Microstoria”. In: Quaderni Storici, vol. 86, a. 29, n. 2, pp. 511-539. 
GOUREVITCH, A. (1993). "L’individualité au Moyen Age. Le cas d'Opicinus de Canistris”, Annales. Économies, Sociétés, Civilisations, n.5, pp. 1263-1280.

GRENDI, E. (1994). “Ripensare la Microstoria?”. In: Quaderni Storici, vol. 86, a. 29, n. 2, pp. 539-549.

HILGARD, E.R, LEARY; D.E. \& MACGUIRE, G.R (1991). The History of Psychology: A Survey and Critical Assessment. In: Annal Review Psychology, vol. 42, pp. 79-107.

JACKSON, S.W (1983). "Melancholia and partial insanity". In: Journal of the History of the Behavioral Sciences, vol. 19, pp. 173-184.

KUHN, Th. (1962). A Estrutura das Revoluções Científicas. São Paulo, Perspectiva.

LAKATOS, Imre. (1989). La Metodología de los Programas de Investigación Científica. Madrid: Alianza Ed.

LE GOFF, J. (1974). "Les mentalités. Une histoire ambigué". In: LE GOFF, J., Faire L'Histoire, Paris, Gallimard, tomo III, pp. 76-94.

. (1993). A Nova História, 1978, São Paulo, Fontes.

(1994). O Imaginário Medieval, Lisboa, Estampa.

LEARY, D. (1987). "Telling likely stories: the rhetoric of the New Psychology". In: Journal of the History of the Behavioral Sciences, vol. 23, pp. 315-331.

LEAHY, T (1987). A History of Psychology: Main Currents in Psychological Thought, Englewod Cliffs, Prentice Hall.

LEROY, P. (1986). "Eléments por une biographie. Le Centre de recherches de Psychologie Comparative d'Ignace Meyerson. Trente ans de Psychologie Historique”. In: Journal de Psychologie Normal et Pathologique, n. 1-2, pp. 93-101.

LIPSEY, M. (1974). "Psychology: preparadigmatic, postparadigmatic or misparadigmatic?”. In: Scientific Studies, 4, pp. 406-410.

MARHABA, S. (1977). Antinomie epistemologiche nella psicologia contemporanea, Firenze, Giunti Barbera.

MEYERSON, I. (1948). Les fonctions psychologiques et les oeuvres, Paris, Vrin.

MINTZ, S. \& KELLOGG, S. (1987). Domestic Revolutions: A Social History of American Family Life, New York, Free Press.

NICHOLSON, I. (1994). "Academic professionalization and protestant reconstruction, 1890-1902: George Albert Coe’s Psychology of 
religion”. In: Journal of the History of the Behavioral Sciences, vol. 30, pp. 348-363.

PALERMO, D.S. (1971). "Is a scientific revolutiontaking place in psychology?”. In: Scientific Studies, 1, pp. 135-155.

PENNA, A.G. (1987). História e Psicologia, São Paulo, Vertice.

PESSOTTI, I. (1976). Pré-história do Condicionamento, São Paulo, Hucite-Editora da Universidade de São Paulo. . (1994). A loucura e as épocas, Rio de Janeiro, Editora 34.

PIÑERO, J.M.L. (1983). Historical Origins of the Concept of Neurosis, Cambridge, Cambridge University Press.

POPPER, Karl. (1993). A Lógica da Pesquisa Científica. São Paulo: Cultrix.

PORTER, R. (1989). "Ragione e follia nella rivoluzione francese”. In: Quaderni Storici, vol. 71, a. 24, n. 2, pp. 563-588.

REVEL, J. (1994). "Microanalisi e costruzione dei sociale". In: Quaderni Storici, vol. 86, a. 29, n. 2, pp. 549-575.

ROGER, J. (1993). "History os Science: problems and practices". In: Nuncius: Annali di Storia della Scienza, a.8, v.l, pp. 3-26.

ROMANO, O. (1974). Psicologia: tra ideologia e scienza, Milano, Mazzotta.

SHALINS, M. (1990). Ilhas de História, Rio de Janeiro, Zahar.

SMITH, R. (1988). “Does me history of psychology have a subject?”. In: History Human Sciences, vol. 1, p. 147-177.

SUPPE, F. (1984). "Beyond Skinner and Kuhn”. In: New Ideas in Psychology, 2, pp. 89-104.

TRILLAT, E. (1991). História da Histeria, 1986, São Paulo, Escuta.

\section{Bibliografia}

ARIÈS, PH. (1981). História Social da Criança e da Família. 1973, Rio de Janeiro, Guanabara.

BENDERSKY, J.W (1988). "Psychohistory before Hitler: early military analyses of German national Psychology". In: Journal of the History of the Behavioral Sciences, vol. 24, pp. 166-182.

BERGER, P.L., \& LUCKMANN, TH. (1976). A construção social da realidade, 1966; Petrópolis, Vozes. (Coleção Antropologia, n. 5).

BIZIERE, J .M. (1983). "Psychohistory and 'Histoire des Mentalitités”. In: The Journal of Psychohistory, vol. 11, n.l, pp. 89-109. 
BORING, E.G. (1927). "The problem of originality in science". In: American Journal of Psychology, vol. 39, pp. 70-90.

. (1929). A History of Experimental Psychology, New York, Century.

. (1942). Sensation and Perception in the History of Psychology, New York, Appleton Century.

. (1963). History, Psychology, and Science: Selected Papers, (Ed.) R.I. Watson, D.T. Campbell, New York, Wiley.

BROŽEK, J. \& HOSKOVEC, J. (1994). "Czech psychology in international context: Three samples from the 1860s-1930s". In: Psychologie und Geschichte, 6(3-4), pp. 341-346.

CANGUILHEM, G. (1977). Ideologia e Racionalidade nas Ciências da Vida, Lisboa, Edições 70.

DE MAUS E, L. (1981). "What is Psychohistory". In: The Journal of Psychohistory, vol. 2, n. 9, pp. 179-184.

DEWSBURY, D.A. (1990). "Wither the introductory course in the history of psychology?". In: Journal of the History of the Behavioral Sciences, 26, pp. 371-377.

DILTHEY, W (1945). Psicología y Teoría del Conocimiento, 1924, México, Fundo de Cultura Economica.

DUBY, G. et alii (1986). História e Nova História, 1980, Lisboa, Teorema. DUHEM, p. (1908). "Salvar os Fenômenos", 1984. In: Suplemento aos Cadernos de História e Filosofia da Ciência, vol. 3.

DUPRONT A (1961). "Problemes et méthodes d' une histoire de la psychologie collective”. In: Annales E.S.C., pp. 3-11.

FIGUEIREDO, L.C. (1994). A invenção do psicológico. Quatro séculos de subjetivação 1500-1900, São Paulo, Escuta-EDUC.

FOUCAULT, M. (1972). História da Loucura, São Paulo, Perspectiva. . (1992). As palavras e as coisas, São Paulo, Fontes.

FREUD, S. (1969a). Leonardo da Vinci e uma lembrança da sua infância, 1910, Edição Standard Brasileira das Obras Psicológicas Completas, Rio de Janeiro, Imago, vol. XI.

(1969b). Moisés e o Monoteísmo, 1939, Edição Standard Brasileira das obras Completas, Rio de Janeiro, Imago, vol. XXIII.

GEERTZ, C. (1973). The Interpretation of Cultures, New York, Basic Books Inc. 
GERGEN, K.J. (1981). "Social Psychology as History". In: Journal of Personality and Social Psychology, v.26, 1973. In: PENNA, AG., História das Idéias Psicológicas, Rio de Janeiro, Zahar.

GINSBURG, C. (1986). Miti Emblemi e Spie. Morfologia e Storia, Torino, Einaudi.

GOLDMANN, L. (1955). Le Dieu caché. Etude sur la vision tragique dans les Pensées de Pascal e dans le théâtre de Racine, Paris, Gallimard.

GOMBRICH, E.G. (1994). Para uma História Cultural, 1969, Lisboa, Gradiva.

GRISET, A (1984). “Foucault, um projecto histórico.” In: A Nova História, Lisboa, Edições 70, pp. 57-64.

JACKSON, S. (1986). Melancholia and Depression: From Hippocratic Times to Modern Times, New Haven, Yale University Press.

JUNG, C.G. (1990). Psicologia e Alquimia, 1975, Petropolis, Vozes.

KEGAN, R. (1988). “Sogni e visioni nella Spagna del 500”. In: Quaderni Storici vol. 68, a. 23, n.2, pp. 595-607.

KEMP, S. (1990). Medieval Psychology, Westport, Greenwood Press.

KOYRÉ, A. (1979). Do Mundo Fechado ao Universo Infinito, 1957, São Paulo, Editora Forense-Editora da Universidade de São Paulo.

LADURIE, E., Le Roy. (1983). Entre los Historiadores, 1989, México, Fondo de Cultura Económica.

LIFTON, R.J. (1989). O futuro da imortalidade. Ensaios para uma era nuclear, São Paulo, Trajectoria Cultural.

MANDROU, R. (1968). "L'Histoire des Mentalités". In: Encyclopedia Universalis, vol. VIII, pp. 436-438.

MASSIMI, M. (1985). História das Idéias Psicológicas no Brasil, em obras do período colonial, Dissertação de Mestrado, Instituto de Psicologia, Universidade de São Paulo.

(1990a). "Conhecimentos acerca do Homem e de sua Subjetividade no Brasil Colonial”. In: Quipu: Revista Latino Americana de Historia de las Ciencias y la Tecnologia Mexico, vol. 7, n. 2, pp. 23-257.

. (1990b). História da Psicologia Brasileira, São Paulo, Editora Pedagógica Universitária.

. (1990). "As definições de Psicologia na cultura brasileira do século XIX”. In: Psicologia: Teoria e Pesquisa, vol. 5, n. 2, pp. 203215. 
. (1991). "O estudo do Homem Moral na faculdade de Medicina do Rio de Janeiro, no seculo XIX". In: Psicologia: Teoria $e$ Pesquisa, vol. 7, n. 1, pp. 71-82.

. (1992a). "As idéias psicológicas de Francisco de Mello Franco, médico e iluminista brasileiro". In: Psicologia: Teoria e Pesquisa, vol. 7, n. 1, pp. 83-90.

. (1993b). "A contribuição de um iluminista brasileiro à História das Idéias Psicológicas”. In: Psicologia: Teoria e Pesquisa, vol.9; n.l, pp. 39-50.

- (1993d). "Visões do Homem e aspectos psicológicos no encontro entre a cultura portuguesa e as culturas indígenas do Brasil, no século XVI”. Documentos e perspectivas de análise. Actas do Congresso Internacional de História: Missionação Portuguesa e Encontro de Culturas, volume II, Universidade Católica PortuguesaComissão Nacional para as Comemorações dos descobrimentos Portugueses-Fundação Evangelização e Cultura, Braga, pp. 609-627. MAZZOLENI, G. (1992). O Planeta Cultural. Para uma Antropologia Histórica, tradução brasileira, São Paulo, Editora da Universidade de São Paulo-Instituto Italiano de Cultura.

MENSCH, T.G. (1979-80). "Psychohistory of the Third Reich: a Library Pathfinder and Topical Bibliography of English Language Publications". In: The Journal of Psychohistory, n. 7, pp. 331-354.

MISRA, G. (1993). "Psychology from a constructionist perspective: an interview with Kenneth J. Gergen”. In: New Ideas in Psychology, vol. 11, n. 3, pp. 399-414.

MORAVIA, S. (1983). "The capture of the invisible: for a (pre)history of Psychology in eighteenth-century France”. In: Journal of the History of the Behavioral Sciences, vol. 19, pp. 370-378.

PEREIRA, M. "L'Alquimia e la Psicologia di Jung”. In: CAROTENUTO, A., Trattato di Psicologia Analitica, Torino, UTET, pp. 415-445, sem data.

PETERSON, G.L. (1981). "Historical self-understanding in the social sciences: the use of Thomas Kuhn in psychology". In: Journal Theory of Social Behavior, 11, pp. 1-30.

PIGEAUD, J. (1981). La maladie de l'âme. Étude sur la relation de l'âme et du corps dans la tradition médico-philosophique antique, Paris, Les Belles Lettres. 
PONGRAZ, L. (1980). Historiography of modern psychology, Toronto, Hogrefe.

ROCCATAGLIATA, G. (1973). Storia delta psichiatria antica, Milano, Hoepli.

. (1981). Le origini della psicoanalisi nella cultura classica, Roma, Il pensiero scientifico.

. (1981). Storia delta psichiatria biologica, Firenze, Nuova Guaraldi.

SHNEIDMAN J.L. \& SHNEIDMAN CL. (1981). "Psychohistory: Expanding the parameters of historical causality”. In: The Journal of Psychohistory, 9 (2), pp. 353-360.

VAN DER BERG, J.M. (1980). Psicologia profunda, São Paulo, Mestre Jou.

VERNANT, J.P. (1960). "Sur les recherches de psychologie comparative historique”. In: Journal de Psychologie Normale et Pathologique, a. 57, n. 4, pp. 445-451.

VERNANT; J.P. (1965). Mito e pensamento entre os Gregos. Estudos de Psicologia Histórica, 1990, Rio de Janeiro, Paz e Terra.

VOVELLE, M. 1991. Ideologias e Mentalidades, 1985, São Paulo, Brasiliense.

WATSON, R.I. (1960). "The History of Psychology: a neglected area”. In: American Psychologists, vol. 15, pp. 251-255.

(1963). The Great Psychologists: Aristotle to Freud, Philapdelphia, Lippincott.

(1966). "The role and use of history in the psychology curriculum". In: Journal of the History of the Behavioral Sciences, vol. 2, pp. 64-69.

. (1967). "Psychology: a prescritive science". In: American Psychologist, pp. 435-553.

. (1971). "Prescription as operative in the History of Psychology". In: Journal of the History of the Behavioral Sciences, vol. 2, pp. 311322.

(1974 e 1976). Eminent Contributors to Psychology, vol.1 e 2, New York, Springer.

. (1979). The History of Psychology and the Behavioral Sciences: A Bibliographic Guide, New York, Springer, 1978. 
Basic Writings in the History of Psychology, New York, Oxford University Press. 


\title{
Fontes em historiografia da psicologia
}

\author{
Josef Brožek* \\ Regina Helena de Freitas Campos**
}

O estudo sistemático da história da Psicologia é um empreendimento relativamente recente. A especialidade tem-se consolidado principalmente a partir da criação da Divisão de História da Psicologia da American Psychological Association, em 1965. Antes disso, alguns pioneiros haviam se preocupado em registrar principalmente a evolução da Psicologia Científica (Boring, 1950; Murphy, 1932), a partir de uma perspectiva internalista. Contava-se a história da Psicologia como o desenvolvimento de maior precisão nos conceitos e procedimentos de investigação utilizados, como um avanço na acumulação de conhecimentos (Campos, 1991). Com a formação de especialistas na área, os métodos de reconstrução historiográfica se tornaram mais sofisticados, e o uso de fontes primárias se intensificou. Também as relações entre a história da Psicologia e a história social ou cultural têm sido mais extensamente exploradas. Com isto, a questão das fontes de investigação historiográfica tem ocupado os especialistas, e arquivos de fontes primárias têm sido progressivamente organizados.

\section{Fontes primárias na historiografia da Psicologia}

As fontes primárias mais utilizadas na reconstrução historiográfica, seja das idéias psicológicas, seja da psicologia científica, têm sido os trabalhos, publicados ou não, de pioneiros no estudo e na elaboração de conceitos sobre fenômenos psicológicos. Massimi (1994), por exemplo, tem estudado textos produzidos no Brasil colonial, para deles extrair as idéias sobre o psicológico e as diferentes concepções de natureza humana neles desenvolvidas.

Já os historiadores da psicologia científica se valem dos documentos encontrados em arquivos de universidades e instituições dedicadas à

\footnotetext{
* Professor na Lehigh University, nos EUA.

** Universidade Federal de Minas Gerais.
} 
pesquisa em psicologia. No Brasil, têm sido estudadas, por exemplo, as teses defendidas por estudantes das Faculdades de Medicina da Bahia e do Rio de Janeiro, durante o século XIX, buscando as concepções de saúde e de doença mental que guiavam o trabalho dos profissionais; concepções estas que ao mesmo tempo refletiam as demandas das elites e formavam mentalidades e instituições (Massimi, 1994, Costa, 1979). Na França, arquivos como os de Alfred Binet e de Henri Wallon têm sido explorados; visando explicitar com mais rigor a evolução dos instrumentos de medida das capacidades intelectuais e sua utilização, ou os processos de institucionalização da psicologia nas universidades (Schneider, 1992).

Em Genebra, na Suíça, um grande esforço tem sido desenvolvido pela Foundation Archives de l'Institut Jean-Jacques Rousseau, sob a direção do Professor Daniel Hameline, na organização do acervo dos pesquisadores do Instituto, que teve grande influência na evolução dos conceitos psicológicos no século XX. No quadro dos trabalhos da Foundation, a Professora Terezinha Rey-Pinto providenciou a catalogação informatizada do Fundo André Rey e desenvolveu investigações no Centro de Documentação e Pesquisa Helena Antipoff, no Brasil, visando levantar e catalogar a extensa correspondência (cerca de 600 peças) mantida entre Antipoff e os pesquisadores do Institut Jean Jacques Rousseau. Deste trabalho resultou a institucionalização de um Fundo Helena Antipoff em Genebra. Daniel Hameline, Arielle Jornod, com a colaboração, em Lisboa e Coimbra, de Antonio Novoa e, em Varsóvia, de Jürgen Helmchen, iniciaram o levantamento dos anos iniciais do Instituto (1912-1924) e sua influência em outros países. Também os arquivos de Jean Piaget foram organizados e colocados à disposição dos pesquisadores interessados. Malika Belkaïd ficou encarregada da catalogação do Fundo Geral do Instituto Jean Jacques Rousseau.

Nos Estados Unidos, foi organizado, em 1965, um arquivo de História da Psicologia norte-americana centralizado na Universidade de Akron, sob a direção do pesquisador John A. Popplestone. Este acervo preserva coleções de manuscritos, isto é, materiais gerados a partir do trabalho de um autor, e arquivos, ou seja, materiais relativos a uma organização ou publicação periódica. As coleções de manuscritos incluem documentos não-publicados, correspondências, boletins e outros materiais de circulação restrita, gravações, filmes e fotografias. Os arquivos guardam documentos não publicados gerados por organizações ou editores de 
revistas científicas. Além disso, em Akron estão depositadas coleções de objetos relevantes, como equipamentos de laboratório obsoletos. Os arquivos estão organizados por autor (indivíduos ou organizações), nomes de periódicos, testes, instrumentos, fotografias e filmes. Os materiais foram doados aos arquivos por famílias de autores ilustres, ou por organizações, e os doadores detêm o direito de estabelecer as condições de uso, que incluem as seguintes categorias: 1) uso irrestrito; 2) autorização apenas para leitura, sendo a permissão para citar sujeita a restrições; 3) permissão para a leitura ou citação por escrito requerida; e finalmente 4) material não disponível para consulta por um tempo determinado pelo doador. Os arquivos são mantidos por pessoal treinado nas técnicas arquivísticas, mas com extenso conhecimento em Psicologia, que se encarrega de orientar os pesquisadores na consulta.

No Brasil, as fontes primárias de consulta estão disponíveis na Biblioteca Nacional, no Rio de Janeiro, que dispõe de extensa coleção de textos antigos, que podem fornecer preciosas evidências sobre as idéias psicológicas elaboradas no passado. Encontram-se nesta categoria também os livros e manuais de teologia e filosofia adotados em seminários e escolas secundárias.

Outras fontes para a consulta podem ser encontradas em bibliotecas universitárias e em arquivos privados de pioneiros da Psicologia no Brasil. Este é o caso do acervo do Centro de Documentação e Pesquisa Helena Antipoff, que contém a documentação inédita que pertenceu à psicóloga e educadora, uma das pioneiras no ensino e na pesquisa em Psicologia no país. Este acervo está sendo organizado e catalogado por uma equipe de pesquisadores da Universidade Federal de Minas Gerais (Campos, 1996).

\section{Fontes secundárias}

A partir de 1965, com o início da edição do periódico intitulado Journal of the History of the Behavioral Sciences, ampliou-se muito a divulgação de estudos em história das ciências humanas e sociais, incluindo a psicologia. O periódico publica regularmente relatos de investigação e resenhas de livros contendo estudos históricos.

O ano de 1979 não foi só o centenário da fundação do laboratório de psicologia experimental de Wundt, em Leipzig. Foi também um centenário 
de um acontecimento de significado mais restrito: a nomeação de David Jayne Hill, aos 29 anos, como Presidente de uma pequena universidade da Pensilvânia oriental, Universidade de Lewisburgo, que logo mudou de nome, e que conhecemos hoje como Bucknell University. Entre outros, Hill tomou a iniciativa de reeditar o compêndio de psicologia Elements of Psychology, que apareceu no prelo pela primeira vez em 1888. O livro - e o autor mesmo - representa a fase de transição nos Estados Unidos entre a psicologia tradicional, filosófica, e a psicologia científica, moderna.

No ano de 1974 a Universidade Bucknell decidiu comemorar o evento com a publicação de uma obra científica. O Professor Josef Brožek foi convidado a editar uma coletânea de monografias. A coletânea foi finalmente editada em 1984 com o nome de Explorations in the history of psychology in the United States. As monografias individuais tratam dos seguintes tópicos: origens da psicologia acadêmica norte-americana; a teoria da mente, formulada por um pastor; a psicologia da motivação, esboçada por William James; laboratórios pioneiros; e James McKeen Cattell e a psicologia norte-americana nos anos de 1920.

A contribuição de Brožek foi a biografia do próprio David Jayne Hill. É de interesse o fato que no ano de 1881 o título acadêmico de Hill mudou de "Professor de metafísica e filosofia mental" a "Professor de psicologia e ética". Aqui o relevante é a mudança de "mental philosophy" a "psychology". Conforme o que sabemos, Hill foi o primeiro norteamericano que recebeu o título de "Professor de psicologia". Seja como for, a mudança de "filosofia mental" a "psicologia" é documentada de maneira convincente.

As traduções também podem abrir fontes de informação relevantes à história da psicologia, antes não acessíveis. A inacessibilidade pode ter duas razões: a língua dos materiais originais e sua localização.

Brožek providenciou a tradução de diversas obras científicas, antes inacessíveis ao público de língua inglesa. Sua primeira tradução de uma obra científica tem uma história divertida: seu gosto pelos livros, não só pelo seu conteúdo, mas também por causa de seus valores estéticos. A qualidade do papel, a impressão e a capa induziram-no a interessar-se por uma série de livros, intitulada Dutch classics in the history of science, ou seja, uma coleção de clássicos holandeses da ciência, uma série distinta, patrocinada pela Sociedade Holandesa para a História da Medicina, 
Matemática e Ciências Exatas. Querendo contribuir para a série, descobriu uma dissertação de doutorado defendida na Universidade de Utrecht. O seu autor foi Johan Jacob de Jaager e o título Die physiologische tijd bij psychische processen ( $\mathrm{O}$ tempo de reação que caracteriza os processos mentais). Era uma obra de importância fundamental para a história da psicologia, mas essencialmente desconhecida: existem poucos historiadores da ciência que podem ler textos em holandês! A dissertação tratava da obra de Franciscus Cornelis Donders (1818-1889), um fisiólogo (e mais tarde oftalmólogo) célebre. Donders serviu também como "sujeito experimental”. Foi Donders quem escreveu, no mesmo ano de 1865, uma "nota preliminar" sobre "a velocidade do pensamento e a tomada de decisões". Um artigo de Donders, mais longo, mas também designado como "preliminar”, apareceu no ano de 1868, em alemão.

Outro autor traduzido foi Pierre-Louis Moreau de Maupertuis, Presidente da Academia Real de Ciências e Literatura de Berlim, que escreveu - em francês - uma "Carta concernente ao progresso das ciências”. A Carta faz parte das “Obras” (Oeuvres) de Maupertuis, publicadas em Dresden no ano de 1752 e tem uma seção intitulada “Expériences métaphysiques”. Por que deveria interessar a psicólogos e historiadores da psicologia? A expressão não tem nada a ver com "metafísica” ou com "experiências” espiritualistas. A tradução correta do título é "Experimentos psicológicos”. A Carta propõe estudos de funções sensoriais, dos efeitos de drogas que modificassem a consciência humana, mas também a realização de "experimentos em que os estímulos fossem aplicados diretamente ao cérebro”. No meio do século XVIII? Sim: 1752.

Foram os colaboradores de I. P. Pavlov - Yu. P. Frolov (1922) e S. Rozental (1922), que fizeram os primeiros experimentos sobre a conduta os "reflexos condicionados" - de animais. No fim da segunda década do presente século nem os experimentadores de Petrogado nem os seus animais tinham muito a comer. Os resultados foram incluídos em um livro de dois volumes, Biology of human starvation, uma obra cooperativa e interdisciplinar de 1950. A tradução dos relatos demorou 37 anos (Brožek, 1987).

Masaryk, estudante de filosofia com Franz Brentano na Viena dos anos de 1870 com Brožek, interessou-se pela psicologia do período de 1880 até 1900 . Neste tempo atuou como professor de Filosofia na divisão tcheca 
da universidade de Praga. As traduções de sua obra, em inglês, fazem parte de um livro publicado pela casa editora da Universidade Carolina, em Praga, no ano de 1995. Os temas incluem: hipnose, aspectos psicológicos da poesia, história e psicologia, imitação, psicologia no sistema das ciências e psicologia da criança.

Fontes inéditas e traduções são importantes, por exemplo, para permitir a resolução de problemas de precedência nas descobertas científicas (Wertheimer et al., 1992), ou de interferências políticas na história das idéias, como é o caso da recepção de traduções de obras da psicologia ocidental em países do Leste europeu.

\section{Referências}

BORING, E. (1950). A History of Experimental Psychology. New York, Appleton Century Crofts.

BROŽEK, J. (Ed.) (1984). Explorations in the History of Psychology in the United States. Cranbury, N.J., Associated Universities Presses.

CAMPOS, R.H.F. (1991). "O Estudo da História da Psicologia: Tendências Contemporâneas”. In: Revista da Universidade de Alfenas 1 (2), jan./dez.

(1996). C. \& R. H.F. (Coord.) Bases de Dados do Centro de Documentação e Pesquisa Helena Antipoff. Belo Horizonte, Universidade Federal de Minas Gerais.

COSTA, J.F. (1979). Ordem Médica e Norma Familiar. Rio de Janeiro, Graal.

HAMELINE, D. (1994). Équipe de Recherche "Unité de philosophie de l'éducation et d'histoire des idées pédagogiques” (UPHILHIS) et Archives Institut Jean-Jacques Rousseau (A.I.J.J.R.). Genebra, mimeo.

MASSIMI, Marina. (1994a). "Considerações Gerais sobre Psicologia e História”. In: Temas em Psicologia 3.

(1994b). "O processo psicológico de conhecimento da realidade social, no Brasil do século XVI: Caminha e piloto anônimo”. In: Temas em Psicologia 3.

MURPHY; G. (1932). A Historical Introduction to Modern Psychology. New York, Hartcourt, Brace \& Co. 
POPPLESTONE, JA. (1993). Archives of the History of American Psychology. Akron, Ohio, University of Akron.

SCHNEIDER, W. (1992). "After Binet: French Intelligence Testing, 19001950". In: Journal of the History of the Behavioral Sciences 28(2), April.

WERTHEIMER, M. et al. (1992). "Carl Jung and Max Wertheimer on a Priority Issue". In: Journal of the History of the Behavioral Sciences 28(1), January. 


\section{PARTE II}

Relatos de trajetórias de historiadores da psicologia 


\section{Josef Brožek: relato de um historiador da psicologia}

Este relato de um historiador da Psicologia deve ser considerado como um estudo de caso (a case study). É uma história individualizada desta especialidade ao longo de 60 anos. As raízes desta história encontramse na primeira metade da década dos anos 30 .

Foi nesse período que o interesse pela história da Psicologia ocorreu na minha vida. No segundo ou terceiro ano de estudos universitários, na Universidade Carolina de Praga, encontrei numa livraria local um livro em língua alemã intitulado Psychologie der Gegenwart - A Psicologia Contemporânea, com um extenso capítulo introdutório, dedicado ao desenvolvimento da psicologia moderna. O seu autor era Hans, professor universitário de Danzig, cidade que, neste tempo, estava sob ocupação alemã, e que hoje recebe o nome de Gdansk. O livro apareceu no ano de 1932, na sua segunda e revisada edição (Leipzig: A. Kroener). Este autor, por não ser da raça preferida de Adolf Hitler, teve seu livro praticamente desaparecido do mercado. Fui realmente afortunado de ter tido a chance de comprar um exemplar dele no ano de 1933! A leitura do livro me tomou em tal medida, que me coloquei em contato com meu professor de Filosofia na Universidade, pedindo-lhe para que eu apresentasse uma análise detalhada deste livro no seminário filosófico que promovia. O número total das sessões do seminário num semestre foi em torno de 12 , sendo que minha apresentação exigiu seis sessões!

O modelo de Henning da Psicologia Contemporânea era circular, no centro estava a psicologia fundamental, experimental. No círculo da periferia foram situadas 25 especialidades de "psicologia aplicada": a psicologia "dos povos", Volkerpsychologie na terminologia de Wilhem Wundt (1832-1920), que tratava, em dez grandes volumes, do desenvolvimento da linguagem, de mitos e de costumes - uma variedade da

\footnotetext{
* Professor na Lehigh University, nos EUA.

** Mestranda em Psicologia pela Universidade Federal de Minas Gerais.
} 
psicologia social. Também eram tratadas a psicologia legal e criminal, estudos sobre linguagem, economia e indústria, arte, moralidade, religião, estados anormais de consciência, ocultismo e parapsicologia, psicopatologia, psicanálise, ambiente físico, psicologia quantitativa, psicologia das diferenças individuais, psicologia genética, psicologia das massas, psicologia social, psicologia cultural, psicologia e valores, psicologia médica, psicologia animal, psicologia da infância, psicologia pedagógica, psicologia do desenvolvimento e psicologia do conhecimento. Cada um destes 25 capítulos é acompanhado por uma bibliografia substancial. Há também uma bibliografia de psicologia experimental: sentidos específicos; psicologia do tempo; atenção; memória e funções mentais superiores; motricidade; instintos; motivação; emoções; personalidade. O capítulo introdutório (pp. 1-47) é dedicado à história da psicologia moderna (este capítulo representou a minha introdução à história da psicologia).

No Velho Mundo, minha especialidade era a psicologia aplicada. Anos mais tarde, mudei-me para os Estados Unidos. Nos primeiros 20 anos, no Novo Mundo, trabalhei como psicobiólogo, mas sempre que podia retomava a trabalhos relacionados à história da psicologia.

$\mathrm{Na}$ minha vida profissional, trabalhei em vários campos da Psicologia, que eu poderia aqui esquematizar:

- Orientação profissional, do inverno de 1936 até o outono de 1937.

- Psicologia industrial, chamada de "psicotecnia” na minha época, do outono de 1937 até o outono de 1939.

- Estudos avançados da psicologia na América, Universidade da Pensilvânia, na Filadélfia, no ano acadêmico de 1939-1940, e na Universidade de Minnesota, 1940-1941.

- Pesquisa no Laboratório de Higiene Fisiológica - um laboratório de biologia humana aplicada, 1941-1958, com ênfase na pesquisa que tratava de nutrição, trabalho visual e desenvolvimento de enfermidade nas artérias coronárias. O Laboratório era uma parte da Escola de Higiene Pública, Universidade de Minnesota.

- Direção do Departamento de Psicologia e Ensino, 1959-1963, na Universidade de Lehigh, cidade de Bethlehem, Pensilvânia.

- Pesquisa em história da Psicologia, 1963-1979. Após o ano, da aposentadoria formal, prossegui os estudos históricos.

As décadas de 40 e 50 foram, para mim, anos de intensa pesquisa interdisciplinar, com ênfase na desnutrição e no estudo dos fatores que contribuem para a doença coronária, também com um breve 
período de estudo experimental da iluminação e rendimento (performance) visual.

Neste tempo, os interesses históricos se restringiram às resenhas de livros, especialmente livros relacionados à vida e obra de Jan Evangelista Purkinje, um fisiólogo de origem tcheca, com interesse considerável na problemática psicológica.

As duas décadas seguintes, as de 60 e 70, foram para mim o período áureo, do ponto de vista da história da Psicologia.

Os anos 60 marcam o período dos grandes desenvolvimentos organizacionais, como a criação da Divisão de História da Psicologia dentro da Associação de Psicologia Americana, o surgimento do Journal of the History of Behavioral Sciences e da Sociedade Internacional para a História das Ciências do Comportamento e Sociais, que leva o nome de Cheiron.

Além das responsabilidades pessoais no campo de pesquisa e ensino, tive responsabilidades sociais. Uma dessas responsabilidades foi estabelecer a história da psicologia como especialidade no quadro da Associação Psicológica Norte-americana (e na cena mundial). Na primeira metade da década de 60 fui membro de um pequeno grupo de pessoas interessadas com seriedade na história da psicologia. R.I. Watson foi o chefe do grupo. Um boletim datilografado serviu como meio de troca de informações.

O ano de 1965 foi marcado por dois acontecimentos:

- Tivemos sucesso em obter um número suficiente de assinaturas para originar o processo que culminou na formação da Divisão 26 da Associação Americana de Psicologia, uma Divisão de História da Psicologia. Hoje em dia a divisão tem mais de mil membros e seu boletim serve não só às necessidades organizacionais da Divisão, mas também como veículo de difusão de artigos científicos respeitáveis.

- O boletim inicial, datilografado, transformou-se em um jornal científico de alta qualidade e de significado internacional, o Journal of the History of the Behavioural Sciences - Revista de História das Ciências do Comportamento.

Em setembro de 1966, recebi a tarefa de organizar a primeira sessão científica da Divisão, realizada em New York.

Em 1968, foi organizado o curso de verão para professores universitários de história da psicologia. A realização desse 
empreendimento, repetido cinco anos mais tarde, representou da minha parte um esforço organizacional maior. A tarefa principal foi ajudar o novo campo a elevar o seu nível científico e pedagógico - "lifting oneself up by pulling on the boot-straps”, quer dizer, reunindo a qualificação existente entre os historiadores norte-americanos da ciência.

Com a ajuda financeira da National Science Foundation e a colaboração do Professor Robert I. Watson, organizei um seminário de seis semanas na Universidade de New Hampshire. O seminário foi um evento da maior importância no desenvolvimento da historiografia norte-americana, descrito em detalhe no novo periódico ("A Summer Institute on the History of Psychology”, Part I, Journal of the History of Behavioural Science, 5, 307-319, 1969; Part 11, ibid., 6, 25-35, 1970).

No curso de muitos anos participei como membro do Conselho Editorial dessa revista. E foi no contexto desse seminário, no interior do nosso aposento em Durham, que nasceu a International Society for the History of Behavioural and Social Sciences (Sociedade Internacional para a História das Ciências Comportamentais e Sociais), mais tarde chamada Cheiron (Cheiron - Internacional).

Em 1969, organizamos a primeira conferência científica dessa Sociedade, em cooperação com Mary Henle, na Universidade de Princeton.

O segundo seminário aconteceu no verão de 1972 na Universidade de Lehigh. Embora oficialmente os seminários de 68 e de 72 fossem abertos para professores universitários de história da psicologia, aceitou-se um número restrito de estudantes. Em ambos os seminários participaram também indivíduos do exterior, que contribuíram de modo importante para o seu sucesso.

Planos para o terceiro seminário foram cancelados por causa da limitação de fundos estatais.

Doze anos mais tarde tive um papel, um papel modesto, na formação da Cheiron - Européia. Durante uma visita em Cambridge, Massachusetts, do Professor Hans Rappard, da Free Universiry of Amsterdam, Holanda, tive a oportunidade de apoiar a idéia de estabelecer uma seção européia da Cheiron. A Cheiron-Européia foi estabelecida em uma reunião organizada na Universidade em que Rappard trabalhou, em setembro de 1982. 
No Brasil, participei como Presidente Honorário no primeiro Seminário de História da Psicologia Latino-americano, organizado por Antônio Gomes Penna no Rio de Janeiro, em 11 e 12 de abril de 1988. Não sei o que aconteceu com a idéia da Cheiron - América Latina.

Na década de 70, os frutos desse trabalho histórico surgiram como artigos científicos divulgados em revistas especializadas e como livros, que seguem anexos ao fim deste relato. Basicamente, nos últimos 25 anos, foram desenvolvidos os seguintes temas de estudo:

1970 - As origens da Psicometria, estudos de J.J. de Jaager sobre "o tempo de reação e processos mentais” (em colaboração com M.S. Sibinga). O livro inclui uma introdução histórica. O texto original está em holandês e a tradução, em inglês.

1972 - Psicologia na União Soviética: uma perspectiva histórica (com Dan I. Slobin).

1977 - Contribuições de R.I. Watson à história da Psicologia (em colaboração com R.B. Evans).

1982 - As origens da psicologia objetiva (uma tradução de um tratado em alemão, publicado nos anos 1976 e 1982).

1984 - Explorações sobre a história da psicologia nos Estados Unidos: uma coleção de monografias.

1985 - Desnutrição e conduta humana (uma documentação histórica).

1987 - J.E. Purkinje e a psicologia (com J. Hoskovec).

1988 - G.T. Fechner e a psicologia: anais de uma conferência internacional (ed. com Horst Gundlach).

1995 - Thomas Garrigue Masaryk sobre a psicologia (com J. Hoskovec).

1997 - 1998 (em preparação) - Idéias psicológicas e a sociedade (19381998), Universidade Carolina de Praga. 


\section{História da psicologia contemporânea: Tchecoslováquia (1990-1992) e República Tcheca (1993-1996)}

Nasci na Boemia, no centro da Europa. Naquele tempo esse país fazia parte do Império Austro-Húngaro. A Tchecoslováquia formouse, no fim da Primeira Guerra mundial, como um país democrático, com viva consciência social. No período da Segunda Guerra (19391945) o país foi ocupado pelas tropas alemãs nazistas. Foram os russos que libertaram a maior parte do país. Num putch de fevereiro de 1948, o partido comunista tomou o poder. O governo comunista caiu em novembro de 1989, como resultado da "revolução mansa". Na televisão, entretanto, podíamos observar a brutalidade da polícia contra os estudantes (este foi o fato que me "radicalizou").

No início do ano de 1990 formou-se o Foro Cívico dos Psicólogos como órgão profissional, com três tarefas principais: a correção das deformações comunistas, a reforma do ensino da psicologia e o estabelecimento de relações com o “mundo livre”. Num período de 42 anos, o país seguiu a orientação política, econômica e ideológica da União Soviética. No país, na psicologia, os comunistas dominavam todos os aspectos organizacionais, pessoais e teóricos.

Uma tarefa importante da "revolução mansa" era corrigir as chamadas “deformações”, forçadas pelos comunistas.

Foi necessário mudar as "velhas estruturas” organizacionais, como a Comissão Central para Educação e Psicologia, ligada à Academia Tcheca de Ciências, e o conselho editorial da revista Psicologia Tchecoslovaca. As chefias das seções geográficas, divisões especializadas e dos grupos de interesse profissional foram substituídas por "sangue novo”. Anteriormente controlados por órgãos centrais, todos os ramos da Sociedade Tcheca de Psicólogos tornaram-se independentes, com iniciativa própria (Brožek \& Hoskovec, 1990).

Na Cátedra de Psicologia (Faculdade Filosófica, Universidade Carolina, em Praga), Sonha Hermochova, recusada no ano de 1965 por razões políticas, obtém a possibilidade de defender a sua tese de habilitação, conquista seu grau de "Candidato de Ciência", equivalente ao doutorado (Ph.D.) americano, em 1990. No ano seguinte, 1991, foi eleita presidente da Cátedra de Psicologia. 
Karel Balcar, empregado no Instituto de Educação Contínua de Médicos e Farmacêuticos, publicou em 1983 um compêndio sobre a personalidade. Dois anos mais tarde, os ideólogos do Partido Comunista censuraram o livro severamente, por citar fontes ocidentais positivistas e personalistas, sem uma "apropriada", entenda-se aqui, marxista, crítica de seus fundamentos filosófico-teóricos. No ano de 1991, Balcar recebeu um posto na Cátedra de Psicologia.

Por razões políticas, no ano de 1972, os poderes universitários haviam liquidado o Instituto de Pesquisas Psicológicas e despediram o seu chefe, Milos Machac. O Instituto reestabeleceu-se no ano de 1991. V. Brichacek, despedido no ano de 1971, assumiu a chefia do Instituto.

$\mathrm{Na}$ área do ensino, o currículo sofreu importantes mudanças. Entre outras, a duração do curso de graduação, reduzido de 5 para 4 anos, voltou a ser de 5 anos. Os cursos ideológicos, como a história do partido trabalhista, desapareceram, e a participação de estudantes na administração e na política universitária cresceu. No Conselho Universitário os estudantes passaram a ter $50 \%$ dos votos.

O número de associações de psicólogos especializados em campos diferentes da psicologia aplicada aumentou, com associações de consultores para assuntos conjugais e familiares, psicologia escolar, psicologia do trânsito, psicologia clínica, psicologia industrial e organizacional e outros.

Apareceram revistas psicológicas novas, porém, em mais de um caso, tiveram breve duração.

Cresceu também o número e a diversidade das organizações que prestam serviços psicológicos.

Reuniões científicas, em muitos casos com participação internacional, multiplicaram-se como cogumelos depois das chuvas. Reuniões internacionais, organizadas na Eslováquia, tiveram como temas a "Psicologia Social no Século XX", a Psicologia Escolar, ou a "Psicologia numa região do Danúbio” (Brožek e Hoskovec, 1993).

No fim de dezembro de 1992, a República Federal Tcheca e Eslováquia separou-se em República Tcheca e na Eslováquia. Um relatório que retrata a situação presente da Psicologia Tcheca faz parte do livro Psychology in Europe, editado por Angela Schorr e Salli Saari (1995). 
Os contatos internacionais podem agrupar-se em cinco categorias: visitas de psicólogos estrangeiros;

- visitas de psicólogos tchecos ao exterior;

- informações que concernem à psicologia internacional, na forma de relatos e de resenhas de livros publicados fora do país;

- estudos em colaboração; e

- reuniões internacionais.

\section{Pesquisa em arquivos}

1) Meus primeiros estudos em arquivos (Brožek, 1973a, 1973b) estão relacionados com Marcus Marulus (1450-1524), humanista, croata, mais precisamente, dalmata, da Dalmácia. Marulus escreveu (mas não publicou) o livro intitulado Psychologia De anima humana liber. Segundo o que sabemos, é a primeira obra com o título de Psychologia, ou, para ser mais preciso, Psichiologia. É um termo neo-greco, latinizado, substituído pelo título de um tratado de Aristóteles, Peri psyches, em latim, De anima.

Marulus escreveu o livro - não conhecemos a data precisa - na cidade de Split, Spalatum, Spalato no italiano. Quis ver, com meus próprios olhos, todas as cópias da biografia de Marulus, escrita por seu amigo mais jovem, Franciscus Natalis, latinizado do croato "Bozevic". É a biografia que contém o nome do livro. A biografia apareceu no prelo 200 anos mais tarde. Visitei os arquivos das cidades da Iugoslávia (Dubrovnik, Split, Zadar, Zagreb), Budapeste, na Hungria, e Veneza na Itália. A biografia mesma apareceu no prelo alguns 200 anos depois de ser escrita (Natalis, 1765, pp. 433-435).

Por que ver os manuscritos? O que eu fiz foi um estudo ortográfico. De fato, em cada manuscrito, a ortografia era diferente! Os que transcreveram os manuscritos não sabiam o que fazer com o neologismo. O escritor do manuscrito do Zagreb deixou o termo! Uma mão desconhecida, mais recente, o substituiu pelo termo "etologia".

2) Nas décadas de 70 e 80 foi possível visitar várias vezes os arquivos da Universidade Carolina e da Academia Tchecoslováquia de Ciências, com bolsas de estudo concedidas pela Academia Nacional (Americana) de Ciências. 
Em sua maioria, estes estudos centraram-se na transcrição de manuscritos de apontamentos para lições universitárias que J.E. Purkinje lia na Universidade de Vratislávia (Breslau, hoje Wroclaw, em polaco) entre os anos 1827 e 1842. Os títulos das lições eram "Psicologia empírica” e "Psicologia fisiológica” (Brožek e Hoskovec, 1987, pp. 20-76 e pp. 77101). Lamentavelmente, nossas expectativas foram frustradas. Não só os apontamentos eram incompletos, especialmente com relação à psicologia fisiológica, como não indicavam se as fontes e o nível correspondiam ao nível geral das publicações do autor.

3) Muito mais recompensadores foram os estudos do desenvolvimento na Tchecoslováquia da psicologia aplicada entre as guerras mundiais (Brožek e Hoskovec, 1986), suplementados por uma lista de dissertações doutorais apresentadas neste período (Brožek e Hoskovec, 1986b).

Em parte, o estudo teve como objeto a história complicada da instituição principal da psicologia industrial, que foi estabelecida no ano de 1920, com o título de Instituto Psicotécnico. O título mudou mais de uma vez. O Instituto encerrou suas atividades no ano de 1951, terceiro ano do regime comunista.

4) A biografia de David Jayne Hill, uma figura que marca a transição nos Estados Unidos entre a "velha Psicologia”, filosófica, e a "Psicologia nova”, científica e experimental, baseou-se em estudos de arquivos. No ano de 1881, Hill recebeu o título de Professor de Psicologia, o primeiro no mundo (Brožek, 1984).

5) Numa visita à Europa, no começo dos anos 70, nos arquivos da Universidade de Utrecht, Holanda, vi um manuscrito incompleto de EC. Donders, o pesquisador da velocidade dos processos mentais (na década de 60). A morte de sua filha deprimiu Donders em tal medida que ele não pôde continuar a obra que prometia ser um dos livros de base da psicologia moderna.

\section{Historiografia da psicologia científica}

Um de nossos trabalhos, cujo tema é “A história da psicologia ao redor do mundo" ("Study of the history of psychology around the world”), publicado na Revista de Historia de la Psicologia, de 
Valencia (1983, 4(4):293-346), especifica como objeto o tema “desenvolvimentos institucionais e organizacionais".

Quais são os tópicos específicos deste trabalho?

1) Na cena internacional, congressos e simpósios;

2) Maiores empreendimentos, como o importante "Vocabulário Histórico de Filosofia”, com 12 grandes volumes, Psicologia do Século XX (Die Psychologie des 20. Jahrhunderts), publicada nos anos 1976-1981;

3) Sociedades internacionais de história da psicologia;

4) Jornais especializados.

Quanto aos contextos geográficos analisados, na área da Ásia e do Pacífico, de interesse principal é a história da psicologia na China. No hemisfério americano, a história da psicologia no Canadá, Estados Unidos, e América Latina. Na Europa, a história da psicologia na Alemanha do oeste e do leste, Itália, Suíça e a União Soviética. Além de conferências, sociedades e revistas, consideram-se arquivos, museus, instituições acadêmicas e também grupos e organizações de pesquisa.

Participei num período de 30 anos, isto é, desde 1966, deste projeto de historiografia da psicologia ao redor do mundo.

O livro Historiografia da psicologia moderna, editado em colaboração com o professor L.J. Pongratz, da Universidade de Wurzburg, e publicado no ano de 1980, contém a história do projeto. O "Progress Report” (pp. 71-73) apresenta uma lista de 18 países estudados e uma lista de dez artigos relevantes. Esse livro contém relatos da literatura recente alemã, latino-americana, soviética e espanhola, escritos por autores diferentes. Em preparação estão relatos da literatura russa e espanhola. Seguir-se-á um relato amplo de literatura alemã.

O projeto que culminou na edição do livro Historiografia da psicologia moderna teve raízes no ano de 1965, ano do nascimento da Divisão de História da Psicologia na APA. O primeiro programa da nova divisão deveria ser apresentado na próxima reunião anual da Associação.

Era a minha responsabilidade organizar o programa. Bem, mas na base de quê? Tendo em vista que faltavam informações sistemáticas referente aos interesses e pesquisas correntes dos membros da 
Divisão de História, preparei um questionário e mandei a todos membros.

Na base desta informação organizei o programa. Além disso, preparei um relatório, publicado no Journal of the History of the Behavioral Sciences.

As obras do Professor Antonio Gomes Penna, publicadas entre os anos de 1980 e 1987, foram o centro de um relato: "Desenvolvimentos recentes na História da Psicologia Brasileira" - "Recent developments in me historiography of psychology in Brazil”. (Teorie e Modelli, Bologna, V. 3-8, 1988.)

O relato do Primeiro Seminário de História da Psicologia na América Latina (Rio de Janeiro, 11-12 Abril de 1988), escrito por Ulfried Geuter e o presente autor, apareceu nas páginas 18-19 de Cheiron-Europe Newsletter, na primavera de 1989.

Publiquei ainda um retrospecto da literatura historiográfica brasileira dos anos 80 ("Braziliana: The later 1980s", History of Psychology Newsletter, Division 26 of the American Psychological Association, 23, pp. 12-19, $n^{\circ} .1 / 2$, Spring/Summer 1991). O enfoque do relato foi a monografia de Marina Massimi, História da psicologia brasileira: da época colonial até 1934 (São Paulo: Editora Pedagógica e Universitária, 1980).

O problema das publicações referentes à literatura contemporânea ocupou-me durante estes últimos 30 anos.

\section{Livros de Josef Brožek}

BROŽEK, J. (1969). "Spectrum of Soviet Psychology: 1968 model”. In: American Psychologist 24, p. 944-946.

BROŽEK, J. \& SIBINGA, M.S. (1970). Origins of Psychometry: J.J. de Jaagers “Reaction Time \& Mental Processes”(1865, em holandês). Nieuwkoop, Holanda: B.de Graaf.

BROŽEK, J. (1970). "Citation longevity and the timing of mental operations". In: Proceedings of the 78th Annual Convention, American Psychological Publications, p. 787-788, 1970.

BROŽEK, J. \& D.I. SLOBIN, (ed. \& contrib.) (1972a). Psychology in the URSS: An Historical Perspective. White Plains, Nova York: International Arts and Sciences Press. 
BROŽEK, J. (1972b). "Quantitative Explorations in the History of Psychology in Yugoslavia: Translations” In: Psychological Reports, 31, p. 397-398.

BROŽEK, J. \& EVANS, R.B. (1977). R.I. Watsons Selected Papers on the History of Psychology. Durham, NH: University of New Hampshire. BROŽEK, J. \& PONGRATZ, L.J. (ed. \& contrib.) (1980). Historiography of Modern psychology. Toronto: C.J. Hogrefe.

BROŽEK, J. (1980). "Quantitative Approach: Wundt in America". In:

BROŽEK, J. \& PONGRATZ, J.L. (Eds.) Historiography of Modern

Psychology. Toronto: C.J. Hogrefe, pp. 290-301.

BROŽEK, J. \& DIAMOND, S. (1982). Le Origini della Psicología Obbietiva. Roma: Bulzoni Editore.

BROŽEK, J. (ed. \& contrib.) (1984). Explorations in the History of Psychology in the United States. Lewisburg, PA: Bucknell University Press.

(1985). Malnutrition and Human Behavior: Experimental, clinical, \& community studies. Nova York: Van Nostrand Reinhold Co.

BRÓZEK, J. \& L.J. PONGRATZ, (eds. \& contrib.) (1986). Storiografia della Psicologia Moderna. Torino: Centro Científico Torinense.

BROŽEK, J. \& HOSKOVEC, J. (1987). J.E. Purkinje. Praga: Academia. BROŽEK, J. \& HOSKOVEC, J. (1995). Thomas Garrigue Masaryk on Psychology: Six facets of the psyche. Praga: Charles University. BROŽEK, J. \& GUNDLACH, H. (eds. \& contrib.) (1988). G.T Fechner and Psychology. Passau, Alemanha: University of Passau Press. 


\section{Estudos históricos acerca da psicologia brasileira: uma contribuição}

Marina Massimi*

A questão básica que fundamenta os estudos que venho desenvolvendo é a da identidade da Psicologia brasileira. Para compreender esta identidade, a reconstrução histórica tem demonstrado ser um recurso fundamental. As investigações por mim realizadas desde 1982 apontam para alguns “percursos” promissores, no âmbito dessa reconstrução; os quais serão discutidos a seguir.

\section{A definição da linha de pesquisa "Estudos históricos em psicologia e história das idéias psicológicas na cultura brasileira”}

Ao longo desses anos de trabalho, manifestou-se a necessidade de definir as características teóricas de uma linha de pesquisa que pudesse dar organicidade e abrir novas perspectivas ao percurso até então realizado.

Em primeiro lugar, uma vez consolidada a opção por dedicar-se aos estudos históricos, cabe esclarecer o objeto geral de tais estudos.

Tal objeto não é restrito à Psicologia científica, mas abrange o domínio das assim-chamadas “idéias psicológicas”. Apesar dessa expressão ter sido criticada nos anos 70 por ter uma conotação “idealista”, é hoje em dia recuperada no contexto da História Cultural, sendo utilizada para denominar todas as elaborações conceituais e todas as práticas de intervenção com indivíduos e grupos, geralmente definíveis como “psicológicas”, mas formuladas e aplicadas em épocas anteriores ao advento da Psicologia científica, por diferentes culturas e em diversos contextos geográficos e sociais. Por outro lado, reconstruir a evolução histórica das Idéias Psicológicas significa abordá-las no seio de seu contexto de produção, a saber, não como meros produtos intelectuais e sim, como expressões de experiências de vida estruturadas em mentalidades, que seriam específicas de diversas coletividades humanas em diferentes

${ }^{*}$ FFCL, USP, Ribeirão Preto. 
domínios espaço-temporais. Em suma, é preciso estabelecer nexos entre a História das Idéias Psicológicas, a História das Mentalidades, a Antropologia Histórica e as demais disciplinas complementares que se fazem necessários para examinar as temáticas próprias da História das Idéias no seu contexto de produção originário.

Como objeto da "História das Idéias Psicológicas" pode ser considerada toda e qualquer colocação sob forma discursiva de assuntos psicológicos. Por sua vez, os assuntos psicológicos podem ser selecionados e diferenciados conforme quatro tipos diferentes de categorias:

a. categorias estritamente psicológicas, relacionadas à "Psiqué" entendida no sentido etimológico do termo. $\mathrm{O}$ estudo da "Psiqué" abrange uma grande gama de conceitos, teorias e métodos, dependendo dos diferentes significados atribuídos à palavra "Psiqué" ao longo da história da cultura;

b. categorias mentais, que se referem à estrutura e às funções da mente humana, definidas no sentido explicitado pela filosofia cartesiana e, posteriormente, reelaborado pelas psicologias mentalistas;

c. categorias comportamentais, incluindo-se toda e qualquer observação, método ou teoria acerca do comportamento humano ou animal. Embora o significado científico de tais categorias tenha sido aclarado só recentemente pelas escolas funcionalista e behaviorista, sua utilização no seio de várias áreas da cultura humana (por exemplo, Filosofia Natural, Pedagogia, Ética) é muito antiga, originando toda uma tradição de Psicologia Objetiva;

d. categorias antropológicas, incluindo roda e qualquer observação, método ou teoria acerca do ser humano, sua natureza, existência e comportamento, globalmente considerados.

Esta delimitação do objeto da História das Idéias Psicológicas tem uma conseqüência muito importante no plano metodológico: a necessidade de detectar e contextualizar as "idéias psicológicas" nas diferentes áreas do saber das épocas consideradas, no âmbito de outras disciplinas, às vezes já estruturadas e institucionalizadas. Tal necessidade não caracteriza apenas a História das Idéias Psicológicas, mas também a História das Ciências em geral, pois, em várias épocas históricas, encontram-se textos que, rotulados como "filosóficos", podem documentar ao mesmo tempo o período de 
"gestação ideológica" de conceitos e métodos que serão repropostos pelas ciências modernas.

Estas categorias gerais proporcionam um crivo para a seleção, a classificação e a organização das fontes levantadas que respeite a sua significação peculiar relativa ao contexto espaço-temporal de sua produção, evitando leituras e interpretações reducionistas ou preconceituosamente distorcidas pela ótica do presente.

Uma vez definida a área "História das Idéias Psicológicas", podemos esclarecer o significado da expressão "História das idéias psicológicas na cultura luso-brasileira da época colonial”, enquanto linha de pesquisa. A escolha aparentemente inusitada de reconstruir uma história das idéias psicológicas neste contexto nasce da seguinte convicção: os elementos que caracterizam a cultura brasileira no contexto do mundo ocidental e os possíveis aspectos de inovação e de originalidade por ela sugeridos no âmbito psicológico somente podem ser apreendidos numa perspectiva ampla e a partir de suas raízes históricas mais profundas.

Embora evidentemente na época colonial não houvesse uma Psicologia no sentido atual do termo, é possível reconstruir uma História das Idéias Psicológicas características da cultura luso-brasileira através da leitura de alguns textos representativos da mesma. Os resultados de uma primeira tentativa desenvolvida a esse respeito foram propostos na dissertação de Mestrado, orientada pelo professor doutor Isaías Pessotti e apresentada no ano de 1985 e sucessivamente sintetizados em alguns artigos (1986; 1990; 1991; 1993). Neste trabalho, cujo título é História das Idéias Psicológicas no Brasil em obras do período colonial, após consulta a alguns catálogos bibliográficos e após um levantamento prévio realizado em Bibliotecas de São Paulo e Rio de Janeiro, foram escolhidas e analisadas 16 obras de autores brasileiros da época colonial, nas áreas de Medicina, Literatura Moral, Teologia, Política, Pedagogia, Arquitetura, contendo páginas dedicadas ao estudo de conteúdos inerentes à vida psíquica.

Os autores (médicos, filósofos, pregadores, educadores e moralistas) realizam, na maioria das vezes, sua formação cultural no exterior, mas, uma vez regressados ao Brasil, desenvolvem aqui uma atuação muito significativa nos campos da cultura, da educação e da política nacionais. Por isso, o interesse demonstrado por estes autores para os conhecimentos e as práticas psicológicas representa, a meu ver, um fator sintomático da 
relevância que tais conhecimentos e práticas assumem no contexto da mentalidade brasileira do período.

Esta primeira experiência historiográfica enfatizou a oportunidade de dar continuidade à investigação acerca das raízes socioculturais que norteiam conhecimentos e práticas psicológicas, no âmbito da cultura brasileira.

No ano de 1991, às vésperas das comemorações dos quinhentos anos do descobrimento das Américas, discutiu-se muito sobre este acontecimento e suas diversas significações e implicações nos vários campos da cultura mundial. Alguns autores, como, por exemplo, Chaunu, Todorov, Boxer, Randless, já haviam apontado as conseqüências do Descobrimento dos Novos Mundos no que diz respeito à formulação do conceito de homem e de humanidade. A partir da leitura de textos desses autores, nasceu em mim o interesse em estudar a significação deste acontecimento histórico, do ponto de vista antropológico e psicológico, dando origem a um projeto de pesquisa cujo título geral é História das Idéias Psicológicas na cultura luso-brasileira dos séculos XVI e XVII.

A hipótese que fundamentava este projeto era a de que o entendimento das mudanças ocorridas no plano intelectual, quanto ao processo de elaboração dos conhecimentos antropológicos e psicológicos ao longo do século XVI, na cultura portuguesa, possibilitaria a compreensão das continuidades e das descontinuidades existentes na dinâmica histórica que gerou o homem ocidental moderno. Seria possível reconhecer, especialmente, as modalidades com que as heranças do mundo clássico e da Europa medieval e os questionamentos e os valores da civilização renascentista compararam-se com os Novos Mundos e com a diversidade de experiências antropológicas neles encontradas. O Brasil é um interessante "observatório" deste processo, sendo que sua própria configuração sociocultural é produto dele.

O projeto previa, como primeira etapa, o levantamento de todo o material documentário útil à indagação desse tema em acervos de Portugal, Itália, Espanha.

A realização desta primeira parte do Projeto ocorreu no ano de 1991. Entre os acervos visitados, merece destaque o Arquivo da Cúria Geral da Companhia de Jesus, em Roma - sem dúvida, um dos acervos mais ricos e 
completos de fontes sobre a história do Brasil quinhentista, pois nele encontra-se a coleção completa das cartas manuscritas anuais e quadrimestrais redigidas pelos Padres e Irmãos residentes nas diversas Capitanias da Terra de Santa Cruz, a partir do ano de 1549, data da chegada dos padres missionários.

Ao longo do levantamento documentário, foram coletados dois tipos de fontes: documentos que se referem à caracterização psicossocial do índio brasileiro, elaborados por autores do século XVI, por um lado, e documentos expressivos dos conhecimentos psicológicos na cultura portuguesa quinhentista, por outro.

As fontes do primeiro tipo foram classificadas em dois grupos: as que foram elaboradas por testemunhas diretas (a saber, roteiros, diários e relatos de viagem; cartas; tratados escritos por viajantes ou colonos); e as que foram elaboradas por testemunhas indiretas (por exemplo, as crônicas históricas acerca do descobrimento e da colonização do Brasil). As fontes do segundo tipo foram agrupadas em tratados filosóficos, jurídicos e teológicos; obras científicas (principalmente médicas); textos de literatura humanista e de literatura ético-catequética.

Alguns resultados parciais da pesquisa já foram apresentados na tese de Livre-Docência bem como em artigos ou comunicações em congressos nacionais e internacionais.

Com efeito, devido à variedade quantitativa e qualitativa das fontes, é possível desenvolver diversos modos e perspectivas de análise das mesmas.

Do ponto de vista da temática abordada, os resultados obtidos no levantamento do material documentário e as primeiras análises desenvolvidas a respeito confirmam a hipótese acerca da relevância do acontecimento histórico do descobrimento e da colonização do Brasil para a elaboração dos conhecimentos psicológicos na cultura portuguesa da época e, possivelmente, na cultura do Ocidente moderno.

A transformação cultural resultante desses eventos pode ser analisada, na perspectiva psicológica, em dois níveis:

1) no plano da História das Idéias Psicológicas, detectando, no contexto da cultura portuguesa quinhentista, as eventuais influências e mudanças de ótica na formulação dos conceitos, induzidas pelo 
reconhecimento da existência de novas e diversas modalidades da experiência humana. Através da leitura das fontes podem ser focalizados conceitos psicológicos relativos ao domínio das relações interpessoais, dos sentimentos, desejos e motivações, da percepção e da cognição. Tais conceitos integram a representação daquilo que pela cultura portuguesa da época é definido como "Homem Moral", categoria esta que se encontra formulada freqüentemente nos textos quinhentistas, para definir o conjunto de fenômenos subjetivos e comportamentais que caracterizam a personalidade humana.

Desse modo, à análise histórica caberá investigar a categoria de "Homem Moral" assim como ela é formulada na cultura portuguesa quinhentista, bem como a maneira com que ela é aplicada à descrição e à explicação do comportamento do índio nas crônicas e na literatura de viagem elaboradas pelos portugueses naquela época.

2) no plano da vivência subjetiva e intersubjetiva, analisando os fenômenos psicológicos envolvidos nos processos de descobrimento e convivência com a alteridade assim como foram relatados pelos protagonistas em cartas, diários de viagem, anotações, tratados.

A escolha desta segunda perspectiva de leitura da documentação acarretou uma ampliação dos horizontes de minha investigação historiográfica, do ponto de vista metodológico. Com efeito, descobri que, além das tradicionais História da Psicologia e História das Idéias Psicológicas, existe uma terceira possibilidade de colaboração entre Psicologia e História, a saber, a utilização das teorias e métodos da Psicologia como recursos para a interpretação histórica, caminho este que já está sendo percorrido, por exemplo, pelos historiadores das Mentalidades e do Imaginário.

Neste nível de análise, o estudo se detém, principalmente, na compreensão da dinâmica de reestruturação da identidade psicossocial dos atores envolvidos no processo histórico, assim como esta é descrita e interpretada nos relatos escritos por eles. Nesse sentido, a análise limita-se apenas à consideração das fontes portuguesas, carecendo de documentação escrita para a narração e a interpretação da experiência vivenciada pelos índios brasileiros. 
Outra perspectiva importante para a reconstrução da história da psicologia brasileira é o estudo da institucionalização da psicologia enquanto disciplina - autônoma ou subárea de diversos campos de saber (filosofia, medicina, direito, pedagogia) -, definindo objetos e metodologias específicas.

Uma pesquisa realizada nesta linha foi apresentada como Tese de Doutorado no ano de 1989 (A Psicologia em instituições de ensino brasileiras no século XIX), orientada pelo Professor Doutor Isaías Pessotti. Para a realização deste trabalho, foram levantados documentos relativos à vida acadêmica em algumas instituições de ensino existentes no século XIX nas cidades de Rio de Janeiro e São Paulo, tais como planos de ensino, provas de alunos, manuais, teses e artigos de periódicos produzidos por professores e alunos, currículos, etc.

A investigação apontou para uma evidente e estrutural descontinuidade no percurso histórico de institucionalização da Psicologia no país.

Evidenciou-se que, já desde o século XIX, o ensino de conteúdos psicológicos era desenvolvido em instituições escolares, de nível superior e secundário, pelo menos na área geográfica estudada (as cidades de São Paulo e Rio de Janeiro).

De modo geral, pode-se afirmar que o conhecimento psicológico no Brasil do século XIX consiste na reelaboração do saber produzido na Europa (principalmente na França e na Inglaterra) e nos Estados Unidos. Esta última influência é mais evidente a partir da segunda metade do século XIX, sobretudo pela penetração de grupos protestantes norte-americanos nas instituições culturais e educacionais brasileiras.

A tendência à imitação de modelos culturais estrangeiros é acentuada pelo fato de que a sociedade nacional da época procurava estruturar-se como uma nação ocidental moderna, lançando os alicerces econômicos, políticos e culturais de um processo que deveria levar à sua realização como Nação. Nessa perspectiva, o passado colonial é avaliado negativamente e, na medida do possível, procura-se apagar seus traços - o que, a nosso ver; representa uma das razões da evidente descontinuidade entre as "idéias psicológicas” da época colonial e a "Psychologia” ensinada e elaborada nas escolas do século XIX. 


\section{A preservação da memória histórica da psicologia no Brasil e a integração da história da psicologia no conjunto da história das ciências}

Os levantamentos documentários desenvolvidos, ao longo desses anos, em vários acervos brasileiros, alertaram-me sobre as condições às vezes precárias dos mesmos e, mais amplamente, evidenciaram a oportunidade de chamar a atenção do mundo acadêmico e da opinião pública acerca da urgência de salvaguardar o patrimônio histórico da cultura deste país.

Um trabalho de levantamento de material documentário, desenvolvido ao longo de dois anos (1989/1990), em duas bibliotecas anexas a instituições acadêmicas que tiveram uma função histórica muito importante, no âmbito do mundo intelectual brasileiro - a Faculdade de Direito e a Faculdade de Medicina de São Paulo, atualmente integradas à Universidade de São Paulo - finalizou-se na elaboração de um Catálogo das fontes de História da Psicologia contidas nos dois referidos acervos. Estas fontes, produzidas por médicos, juristas, pedagogos e filósofos brasileiros, em forma de livros, teses ou artigos em periódicos especializados, referemse principalmente às primeiras quatro décadas do século XX e mostram com clareza as diversas modalidades de recepção da nova Psicologia científica pelo contexto intelectual do país. Além disso, foram levantadas e classificadas as produções de psicólogos estrangeiros contidas em tais acervos, sendo dessa forma possível detectar as principais influências exercidas sobre a Psicologia brasileira por autores, abordagens teóricas e escolas representativas da Psicologia científica internacional, num período histórico em que surge a universidade brasileira e a Psicologia passa a fazer parte do conjunto de disciplinas científicas nela ensinadas.

Os referidos estudos sensibilizaram-me a respeito da necessidade de contribuir de alguma forma para a preservação da memória histórica da Psicologia brasileira.

Surgiu assim o plano da criação de um Arquivo, ou Centro de Documentação de História da Psicologia e das Idéias Psicológicas, na cultura brasileira. Um passo muito importante para a realização deste plano foi o estabelecimento de contatos e de colaboração científica com alguns membros da Sociedade Brasileira de História da Ciência, sobretudo os que estavam planejando a criação de um Centro de Documentação em História 
das Ciências (Cesima), que permitisse aos pesquisadores o acesso às fontes fundamentais nessa área de estudos e a conservação da documentação relativa à História da Ciência Brasileira. Nesse Centro, situado na Pontifícia Universidade Católica de São Paulo, caberia também um setor dedicado à Psicologia e às Ciências Humanas. A partir desses contatos, percebi a importância de uma integração com o grupo dos historiadores da ciência. Colaboramos também na implantação de um Programa de Pós-Graduação na área de História da Ciência, junto à referida Universidade.

No ano passado, juntamente com a Professora Doutora Regina de Freitas Campos, propusemos a abertura de uma Seção de História da Psicologia, no seio da Sociedade Brasileira de História da Ciência, proposta que já foi aprovada pela Diretoria da Sociedade.

A repercussão destas iniciativas na Faculdade de Filosofia Ciências e Letras de Ribeirão Preto foi, antes de mais nada, a criação do Núcleo de História das Ciências e Epistemologia, juntamente com alguns outros colegas do Departamento de Psicologia e Educação: o Professor Doutor Lino O. Bueno (Psicologia Experimental) e a professora Marcia T Ferraz (História das Ciências). Os objetivos do Núcleo são dois: por um lado, possibilitar o aperfeiçoamento da formação de docentes e alunos da Faculdade, promovendo debates e palestras com especialistas nacionais e estrangeiros nas áreas de Epistemologia e História das Ciências, tendo em vista a elaboração de programas específicos de formação de pesquisadores em nível de Graduação e de Pós-Graduação; por outro lado, promover a colaboração entre os pesquisadores nestas áreas atuantes na Faculdade, através da organização de Seminários internos para o estudo e discussão de textos de particular interesse e para a comunicação dos resultados das pesquisas desenvolvidas pelos mesmos.

\section{O ensino das disciplinas históricas em psicologia e a formação de jovens pesquisadores na área}

O ensino da História, ou a compreensão da dimensão histórica relativa a qualquer área do saber, como é o caso da "História da Psicologia”, apresenta-se atualmente como uma tarefa especialmente árdua e ao mesmo tempo urgente. Nós nos encontramos hoje em um clima sociocultural que facilita o esquecimento ou a censura da memória, em jovens e adultos, o que, por sua vez, implica num enfraquecimento da 
consciência da própria identidade cultural em indivíduos e sociedades, bem como em um empobrecimento da capacidade crítica. No que diz respeito à formação escolar, os programas tradicionais que organizam o estudo da História nos cursos primários e secundários anulam, em muitos casos, o interesse próprio pela mesma. Tal situação é particularmente evidente no contexto brasileiro, devido a um complexo processo histórico de colonização cultural e social realizado, entre outras coisas, através do obscurecimento da memória do passado e do ocultamento de seus sinais no presente. Aos olhos do historiador que, sob diversas óticas, se aproxime da realidade brasileira, ressalta-se uma aparente descontinuidade que documenta, a nosso ver, a ocorrência de semelhante processo. Essa mesma situação estimula, porém, a necessidade urgente de uma recuperação do passado, que se manifesta sob a forma de um renovado interesse pelas leituras de teor histórico ou pelas narrativas de ficção histórica. Trata-se então de um momento particularmente propício à consolidação dos estudos históricos, pois encontram-se curiosidade e abertura nos estudantes.

No ensino das disciplinas de teor histórico pelas quais sou responsável junto ao Curso de Graduação em Psicologia no campus de Ribeirão Preto, da Universidade de São Paulo, tenho procurado atuar com atenção e coerência frente à necessidade acima descrita.

As disciplinas por mim lecionadas são: "História da Psicologia I”, ministrada no primeiro semestre do primeiro ano de Curso; "Teorias e Sistemas em Psicologia”, ministrada no segundo semestre, e "História da Psicologia II”, matéria optativa ministrada neste mesmo semestre. Sendo estas disciplinas oferecidas nos primeiros anos de formação do aluno, o seu ensino demanda um treino específico no que diz respeito ao método de estudo, sobretudo quanto à leitura dos textos de autores “clássicos” da História da Psicologia e da História das Idéias.

Os critérios que norteiam a elaboração dos programas das respectivas disciplinas são os seguintes: a definição da História da Psicologia como parte da História da Cultura e da Sociedade; a identificação, no âmbito da História da Psicologia, de duas vertentes, a História da Psicologia e a História das Idéias Psicológicas; a oportunidade de que o estudante tenha um contato direto com as fontes da História da Psicologia e das Idéias Psicológicas; a ênfase no fato de que o estudo da História pode desvelar ou evidenciar de maneira mais clara as múltiplas facetas da realidade presente. 
Parece-me que, devido a tudo o que até agora expusemos, a formação dos alunos interessados nos estudos históricos deva ser proporcionada a partir dos primeiros anos do curso, pois trata-se de iniciá-los numa perspectiva intelectual que coloque a dimensão temporal como recurso para a compreensão de teorias e práticas psicológicas. Nesse sentido, é preciso propor alguns "percursos” para introduzir os estudantes nas mencionadas perspectivas, formando aos poucos uma mentalidade histórica (ou "sentido histórico”) e oferecendo ao mesmo tempo instrumentos para capacitá-los do ponto de vista metodológico (quanto ao conhecimento e à consulta dos acervos documentários e quanto à coleta, à leitura e à interpretação das fontes encontradas). Não se trata de uma tarefa fácil, considerando-se também a escassez dos recursos disponíveis (entre outros fatores, a pobreza das bibliotecas no que diz respeito a esta área; a falta de preparo dos alunos formados pelas escolas secundárias, no campo dos estudos históricos; o desconhecimento de idiomas que seriam necessários para a leitura das fontes mais antigas, tais como o francês, o espanhol e o latim).

Levando em conta esta situação e visando a formação de jovens pesquisadores nas referidas áreas de estudos junto ao Departamento de Psicologia e Educação, tenho realizado atividades de orientação de pesquisas monográficas com alunos do Programa de Bacharelado e bolsistas de Iniciação Científica. Tais pesquisas têm o objetivo de abordar aspectos específicos no âmbito de Projetos de pesquisa mais amplos, por mim desenvolvidos, visando a iniciação dos alunos nos estudos históricos em Psicologia, seja no que diz respeito aos métodos de investigação, seja no que diz respeito aos conteúdos a serem enfocados.

Visando objetivos análogos de formação de jovens pesquisadores, num nível mais adiantado, tenho proposto uma linha de pesquisa na área de Estudos Históricos em Psicologia no âmbito do Programa de PósGraduação em Psicologia, recentemente instalado em nossa Faculdade. Nesse Programa, ofereço duas disciplinas: "História da Psicologia: Objetos, Métodos e Problemas" e "Seminários em História das Ciências e Epistemologia”, sendo esta última disciplina ministrada em colaboração com o Professor Doutor José Lino Bueno. A primeira disciplina visa fornecer aos jovens pesquisadores instrumentos conceituais e metodológicos para as investigações de tipo histórico, destacando as diversas maneiras, hoje praticáveis, de estudo da "História da Psicologia". A segunda aborda temáticas históricas e epistemológicas, contando com a 
colaboração de diversos especialistas nacionais e estrangeiros convidados para ministrar palestras ou mini-cursos.

\title{
Em conclusão...
}

Um trecho do romance de Th. Mann, José e seus irmãos, sumariza a evidência que mais claramente pode-se apreender ao longo do trabalho histórico:

\begin{abstract}
Quanto mais se escava no subterrâneo mundo do passado, (...)tanto mais o insondável se diverte em brincar com a nossa paixão interrogante, oferece-lhe pontos de chegada ilusórios, atrás dos quais, assim que atingidos, abrem-se novos caminhos do passado, como acontece a quem, caminhando ao longo das margens do Mar do Norte, não encontra nunca o termo de seu caminho, porque, atrás de cada terreno arenoso de dunas que deseja atingir, outras amplas vastidões atraem para mais além, na direção de outras dunas.
\end{abstract}

Neste percurso sem fim, cada ponto de chegada coincide sempre com o ponto de partida para novas investigações.

\section{Bibliografia}

BROŽEK, J. \& PONGRATZ, L.J. (1980). Historiography of Modern Psychology, Toronto, Hogrefe.

CHARTIER, R. (org). (1989). La correspondance. Les usages de ta lettre au XIXe siècle, Paris, Fayard.

ELLIOT, J. H. (1984). O Velho Mundo e o Novo, 1492-1650 , 1970, Lisboa, Querco.

FERRONHA, A. L. (1991). Introdução. In: ALBUQUERQUE, L (org.), $O$ Confronto do Olhar, Lisboa, Caminho, pp. 9-30.

FIGUEIREDO, L.C. (1994). A invenção do psicológico. Quatro séculos de subjetivação 1500-1900, São Paulo, Escuta-Educ.

GLIOZZI, G. (1977). Adamo e il Nuovo Mondo. La nascita della'Antropologia come ideologia coloniale: dalle genealogie bibliche alle teorie razziali (1500-1700), Firenze, La Nuova Italia Edirrice.

GOMBRICH, E.G. (1994). Para uma História Cultural, 1969, Lisboa, Gradiva. 
HILGARD, E.R., LEARY, D.E. \& MACGUIRE, G.R. (1991). “The History of Psychology: A Survey and Critical Assessment”. In: Annal Review Psychology, vol. 42, pp. 79-107.

HOLANDA, S.B. (1994). Raízes do Brasil, Rio de Janeiro, José Olympio.

LADURIE, E., Le Roy (1983). Entre los Historiadores, 1989, México, Fondo de Cultura Económica.

LE GOFF, J. (1974). “Les mentalités. Une histoire ambigué”. In: LE GOFF, J., Faire L' Histoire, Paris, Gallimard, tomo III, pp. 76-94.

LE GOFF, J. (1993). A Nova História, 1978, São Paulo, Fontes.

LOUREIRO, R. (1991). “A visão do índio brasileiro nos matados portugueses de finais do século XVI”. In: ALBUQUERQUE, L. (org.), O confronto do olhar, Lisboa, Caminho, pp. 259-288.

MANDROU, R. (1968). “L' Histoire des Mentalités”. In: Encyclopedia Universalis, vol. VIII, pp. 436-438.

MAHFOUD, M. \& MASSIMI, M. (1992). "Descobrindo o mundo, descobrir o outro: o processo psicológico de conhecimento da realidade social, no Brasil do século XVI”, Anais, "Congresso Internacional de História 'América 92': Raízes e Perspectivas”, Universidade de São Paulo, 17-21 agosto, no prelo.

MASSIMI, M. (1985). História das Idéias Psicológicas no Brasil, em obras do período colonial, Dissertação de Mestrado, Instituto de Psicologia, Universidade de São Paulo.

(1986). "As origens da psicologia brasileira, em obras do período colonial”. In: Cadernos da Pontifícia Universidade Católica de São Paulo, n. 23, pp. 95-118.

. (1987a). "Psicologia Experimental em São Paulo: dados acerca da contribuição do Professor Ugo Pizzoli”. In: Psicologia, a.13, n.l, pp. 27-36.

- (1987b). "Psicologia Clínica-Experimental em São Paulo: a contribuição de Domingos Jaguaribe”. In: Psicologia, a.13, n.2, pp. $15-26$.

. (1989). A Psicologia em Instituições de Ensino Brasileiras, no século XIX, Tese de Doutorado, Instituto de Psicologia, Universidade de São Paulo.

- (1990). Catálogo de Fontes para a História da psicologia em acervos da cidade de São Paulo, mimeo, FAPESP. 
- (1990). "As definições de Psicologia na cultura brasileira do século XIX”. In: Psicologia: Teoria e Pesquisa, vol. 5, n.2, pp. 203215.

(1990a). "Conhecimentos acerca do Homem e de sua Subjetividade no Brasil Colonial”. In: Quipu: Revista LatinoAmericana de Historia de las Ciencias y la Tecnología. México, vol.7, n.2, pp. 23-257.

. (1990b). História da Psicologia Brasileira, São Paulo, Editora Pedagógica Universitária.

. (1991). "O estudo do Homem Moral na faculdade de Medicina do Rio de Janeiro, no século XIX". In: Psicologia: Teoria $e$ Pesquisa, vol. 7, n. 1, pp. 71-82.

.(1992a). "As idéias psicológicas de Francisco de Mello Franco, médico e iluminista brasileiro”. In: Psicologia: Teoria e Pesquisa, vol. 7, n.l, pp. 83-90.

. (1992b). "O ensino da Psicologia no século XIX na cidade de São Paulo”. In: Paideia, n.3, pp. 26-39.

. (1993a). "O ensino da Psicologia no século XIX na cidade de Rio de Janeiro”. In: Paideia, n.4, pp. 64-80.

(1993b). "A contribuição de um iluminista brasileiro à História das Idéias Psicológicas”. In: Psicologia: Teoria e Pesquisa, vol. 9, n.l, pp. 39-50.

. (1993c). "O ensino da Psicologia nos Seminários Episcopais de Rio de Janeiro e São Paulo no século XIX”. In: Revista da Sociedade Brasileira de História da Ciência, n.9, pp. 41-50.

. (1993d). "Visões do Homem e aspectos psicológicos no encontro entre a cultura portuguesa e as culturas indígenas do Brasil, no século XVI”. Documentos e perspectivas de análise. In: Actas do Congresso Internacional de História: Missionação Portuguesa e Encontro de Culturas, volume II, Universidade Católica PortuguesaComissão Nacional para as Comemorações dos descobrimentos Portugueses-Fundação Evangelização e Cultura, Braga, pp. 609-627). . (1994). "Psicologia na visão de Psicólogos e Psiquiatras brasileiros das primeiras décadas do século XX”. In: Paideia, n.6, pp. 84-99. 
(1995). Descobrimento, ação, conhecimento e poder, no Brasil colonial: estudos histórico-psicológicos, Tese de Livre Docência, Faculdade de Filosofia, Ciências e Letras, USP, Ribeirão Preto.

TODOROV; 1: (1989). La Conquista de América. El problema del otro, 1982, Madrid, Siglo Veintiuno Editores.

WATSON, R.I. (1960). “The History of Psychology: a neglected area”. In: American Psychologists, vol. 15, pp. 251-255. 


\section{Algumas reflexões acerca de minha formação como pesquisadora em história da psicologia}

\section{Mitsuko Aparecida Makino Antunes *}

Refletir sobre um percurso formativo exige a explicitação de um processo que se dá no fluxo do tempo e é, portanto, um esforço de compreensão histórica. Nesse caso, será aqui usado como recurso o exercício da memória.

Não cabe aqui uma discussão teórica sobre a memória, seja como objeto de estudo seja como recurso metodológico; entretanto faz-se necessário tecer algumas considerações. A memória, se concebida como função psicológica construída histórica e socialmente, é sempre situada numa dimensão temporal e espacial, seletiva e multideterminada.

Usar a memória como recurso é trabalhar com uma leitura que se faz a partir do presente, embora seja este um produto histórico. Resgatar o passado tal como se deu na sua totalidade não é completamente possível, nem é tarefa que consiga chegar a ser um produto acabado. Deve-se procurar, no entanto, juntar os elementos disponíveis, organizá-los, buscando compreender suas contradições e a dinâmica de seu movimento e, fundamentalmente, tentar, com a limitação inerente ao olhar do presente, mais se aproximar do passado e compreendê-lo a partir dos sinais que permaneceram. Melhor compreendendo o passado e seu processo de construção, certamente se tornará mais límpida a compreensão do presente, no qual o passado se encontra como uma determinação e base de sustentação.

Enfim, trabalhar com a memória é como brincar com fios e lanternas.

Um fio puxa outro e, este, mais outro. Um foco de luz ilumina espaços que mostram outros e mais outros. Não se anda em linha reta, assim como não se puxam todos os fios, nem se iluminam todos os cantos.

$\mathrm{Na}$ tentativa de refletir sobre meu percurso como pesquisadora em História da Psicologia, muitos conjuntos de fios precisam ser buscados: a pesquisa, a psicologia, a história, a filosofia, a educação. Nada disso

\footnotetext{
* Programa de Estudos Pós-graduados em Psicologia da PUC-SP.
} 
ocorreu isoladamente, os fios encontram-se entremeados e têm sua origem num tempo já distante; buscá-los leva-me para a infância, antes mesmo da entrada na escola.

Passei minha infância e minha adolescência numa farmácia. Mais precisamente, foi no laboratório de uma "pharmacia”, cujas atividades eram em grande parte as "manipulações”, que eu passei os primeiros anos de vida. Graus, pistilos, espátulas, balanças, vidros, rolhas, cápsulas e uma infinidade de "substâncias químicas" competiam com vantagem com bonecas e panelinhas. Os primeiros eram muito mais interessantes para uma criança; era fascinante ver a mudança de cor provocada pela mistura de amoníaco com "lacto-purga" (fenolftaleína), discriminar substâncias pelo cheiro que exalavam ou tentar "fabricar” pó-de-arroz com amido, perfume e anilina.

Já alfabetizada, era particularmente interessante folhear o “Chernoviz”, a "Farmacopéia Brasileira” e o “Tratado Médico da Família”, para descobrir remédios e as doenças para as quais serviam. Na escola, principalmente no ginásio, era bastante prazeroso saber de antemão algumas coisas e, sobretudo, entendê-las melhor. Creio que nesse processo, em que se complementavam as brincadeiras (ou trabalho mesmo) na farmácia e o conhecimento sistematizado pela escola, alicerçou-se o gosto pela "pesquisa", entendida esta como tentativa de conhecer o que era então desconhecido.

A escola, porém, nem sempre vinha ao encontro de meus interesses ou conseguia estimular minha curiosidade e gerar prazer pelo conhecimento. A disciplina “ciências" era obviamente a de que eu mais gostava e na qual sempre me saía melhor. História e Geografia, por outro lado, eram disciplinas pelas quais eu passava fazendo o mínimo necessário para ser aprovada simplesmente; considerava-as "burras” e sem sentido ou utilidade.

“Ilha é uma porção de terra cercada de água por todos os lados” era algo que eu tentava decorar, escrever nas provas e que, todavia, nunca consegui compreender essa pretensa definição. Que o Brasil foi descoberto por Pedro Álvares Cabral, dividido em capitanias hereditárias, Tiradentes foi um inconfidente, a independência proclamada, os escravos libertados e o país tornou-se república (aliás, os conteúdos nunca passaram deste ponto) foi tudo o que vi, tentei decorar, escrever nas provas e, certamente, nunca 
compreendi. Disso tudo, a pior conseqüência foi o desinteresse. Durante muito tempo, considerei a história como um conhecimento morto sobre coisas mortas.

Decididamente, eu preferia a "ciência”, conhecimento vivo sobre a vida, interessante, inesgotável, rica e tangível, que aguçava minha curiosidade para tentar encontrar no mundo suas razões.

Ao ingressar no colegial, optei pela área de ciências físicas e biológicas, tendo consolidada a decisão pelo curso superior em Biologia ou em áreas afins. Entretanto, a firmeza de tal opção desequilibrou-se com a disciplina Filosofia.

Era início da década de 70, governo Médici, anos mais duros da repressão; o movimento estudantil que existira na escola já estava amordaçado. O professor de Filosofia, porém, discutia com os alunos se “o existencialismo era um humanismo”, questionando-os sobre o que eram, quem eram e o que faziam no mundo. Concomitantemente, participávamos do que restara do grêmio, tentando produzir um jornal, promovendo bailes e procurando "ler nas entrelinhas" as músicas de Chico Buarque e Caetano Veloso.

Deve-se aqui, contudo, abrir um parêntese. As disciplinas Sociologia e Psicologia, que deveriam ser dadas por Maria Nilde Mascelani e Neusa Goiano respectivamente, por "afastamento" destas, foram dadas por outras professoras. Em Sociologia, creio que as professoras cumpriram efetivamente e com competência a tarefa de substituir a professora efetiva, sendo a forma e os conteúdos por elas trabalhados somados ao esforço do professor de Filosofia, Bacan. Em psicologia, porém, os conteúdos trabalhados giraram em torno das "glândulas de secreção interna”, que eram por sua vez muito mais bem abordadas pela professora de Biologia; resumindo, passei por esta disciplina como pela História e pela Geografia.

Enfim, a Filosofia desestabilizou minha antes firme opção pela Biologia, embora eu já tivesse começado a me preparar para o vestibular nessa área. No meio do semestre, ingressei no curso de Psicologia, pois apesar da experiência com a disciplina no colegial, acreditava que ela pudesse ser uma possibilidade de conciliação entre os dois interesses básicos - Biologia e Filosofia -, isto é, uma área híbrida do conhecimento, 
em que se faziam presentes tanto as ciências biológicas quanto as ciências humanas.

Iniciei o curso de Psicologia em 1973, ainda sob o governo Médici. Livros, autores e idéias continuavam proibidos quando constantes do index da censura do governo militar. $\mathrm{O}$ medo e a desconfiança eram freqüentes entre alunos e professores, os quais nunca sabiam se quem estava ao lado era um "dedo-duro" da repressão; isso inibia o debate e a livre expressão de idéias, mas não os impedia ou eliminava essa possibilidade; em verdade, estabelecia-se uma comunicação sutil, que permitia a discussão dos problemas sociais do país à luz da Psicologia.

O behaviorismo era a abordagem hegemônica, com ênfase maior na Análise Experimental do Comportamento e, particularmente, na metodologia de pesquisa a ela vinculada. Esse fato, porém, merece uma análise especial, pois é comum a conclusão simplista e geralmente descontextualizada que identifica o behaviorismo, sobretudo as idéias de Skinner e de seus seguidores como expressão do conservadorismo de uma Psicologia que era, mais do que tolerada, articulada aos interesses do regime ditatorial.

Em primeiro lugar, muitos daqueles que faziam de sua prática docente e de pesquisa uma maneira de resistir ao regime, eram os denominados behavioristas. A maioria dos professores que discutiam em sala de aula as questões sociais mais fundamentais era do grupo dos “skinnerianos”, fazendo-o à luz das formulações por eles defendidas. Eram estes que, ao enfatizar os determinantes ambientais e, por decorrência, sociais dos problemas que eram enfrentados pela maioria da população brasileira, nos faziam pensar e refletir de maneira mais ampla e crítica. Não por acaso eram, em geral, estes que defendiam a ação educacional por meio da Psicologia, considerando-a como meio efetivo de transformação da realidade e condição para a democracia. Não posso negar que muitos desses professores influenciaram muito o posicionamento político-ideológico que fui assumindo ao longo do tempo e que se fazem presentes, indubitavelmente, na postura que assumo perante a Psicologia e a pesquisa, ainda que o behaviorismo não tenha sido para mim uma opção teóricometodológica. Creio que o pressuposto ambientalista e a fundamentação materialista da Análise Experimental do Comportamento foram fatores determinantes do posicionamento que muitos de seus defensores 
assumiram. Aliás, o resgate dessa história e uma compreensão mais orgânica desses fatos devem ser urgentemente objeto de pesquisa da História da Psicologia no Brasil.

Por outro lado, foi precisamente esse grupo que fortaleceu a preocupação com a metodologia da pesquisa e o incentivo para o desenvolvimento de atividades nesse âmbito. Algumas disciplinas ocuparam-se diretamente com este tema: Metodologia Científica, Observação, Laboratório de Psicologia Geral e Experimental, Estatística e pelo menos três semestres de Psicologia Experimental (planejamento experimental, elaboração de projetos e execução de pesquisa em diferentes situações). Outras disciplinas ocuparam-se dessa questão indiretamente, trabalhando os conteúdos a partir da leitura de pesquisas realizadas ou incluindo algumas ações próprias da pesquisa em situações práticas, para o desenvolvimento de atividades acadêmicas. Acrescentam-se a isso muitas aproximações com o que consideramos pesquisa bibliográfica, a título também de elaboração de trabalhos acadêmicos, sendo muitas vezes exigidos procedimentos rigorosos não apenas na coleta de dados e amplitude da bibliografia disponível, mas também na apresentação formal do produto obtido; devo ressaltar, inclusive, que um dos trabalhos que realizei nesse nível, para a disciplina Psicologia Escolar e Problemas da Aprendizagem, foi a base da minha dissertação de mestrado.

Estas disciplinas foram justamente as que mais me interessaram, sendo que exerci em várias delas atividades de monitoria. Não existindo na época programas de Iniciação Científica, este era o caminho para o envolvimento com projetos de pesquisas e grupos de estudo com equipes de professores, além da colaboração em sala de aula nas atividades de ensino.

A conjugação do incentivo à pesquisa, o aprofundamento teórico numa abordagem e as atividades de monitoria, ainda que colocados numa única concepção de Psicologia e pesquisa, foi, a meu ver, um privilégio na minha formação. A despeito da unidirecionalidade, considero que uma base teórica sólida, sobretudo, numa abordagem que prima pelo rigor metodológico, deu-me condições para transitar com mais segurança e facilidade por outras perspectivas teóricas e metodológicas.

Ainda na graduação, outro elemento marcante em minha formação foi a disciplina História da Psicologia, que me trouxe concomitantemente a compreensão da Psicologia como produção histórica e os conteúdos 
filosóficos, que desde o colegial se encontravam latentes. Não é necessário dizer que o encontro com essa disciplina foi um momento fundamental para minha formação, pois além de legitimar minha opção pela Psicologia, mostrou-me um caminho possível para me dedicar no futuro. Essa disciplina constituiu-se para mim num momento de síntese, cujo conteúdo foi catalisador de questionamentos e impasses que outros professores nos levavam a discutir e refletir. História da Psicologia contribuía não apenas para a compreensão dos fundamentos filosóficos da Psicologia, mas também para pensá-la global, histórica e, sobretudo, criticamente.

Por outro lado, o antigo interesse pela Biologia encontrou na Etologia uma possibilidade de concretização. Não havia uma disciplina específica que abordasse os estudos etológicos, mas alguns professores estavam vinculados a essa área e realizavam pesquisas no Departamento de Psicologia Experimental da USP. Por intermédio deles, procurei suprir a lacuna com leituras nessa área; foram particularmente relevantes a coletânea denominada "Psicobiologia" da revista Scientific American, as obras de Lorenz e de Tinbergen, além do conhecimento de algumas pesquisas que estavam sendo realizadas.

Entretanto, no quarto ano de graduação, tive as disciplinas Psicologia Escolar e Problemas da Aprendizagem I e II, que não apenas retomavam as questões e discussões feitas em outras disciplinas, como passavam a ocupar-se especificamente da questão educacional brasileira. Era 1977, ampliava-se a resistência à ditadura militar e esta já dava mostras de enfraquecimento; não apenas o movimento estudantil se ampliava, mas as salas de aula podiam então ser palco de discussões de idéias e obras até pouco tempo proibidas. A dimensão política da educação vinha a ser o "chão" sobre o qual se discutiam as possibilidades e as potencialidades da atuação da Psicologia na Educação.

No final do curso, então, mais uma vez encontrava-me dividida: o gosto pela Biologia e a opção pela Etologia de um lado, e de outro a Educação e sua articulação com a ação política e a Filosofia. A solução foi política. Optei pela Educação pelos motivos já mencionados, sobretudo pela idéia de que a atuação educativa poderia ser uma contribuição para a tentativa de superação de uma Psicologia elitista e muitas vezes atrelada a interesses que não os da maioria da população. 
Obviamente, a opção pela pesquisa já havia sido feita muito tempo antes. Ingressei então na pós-graduação em Filosofia da Educação, em busca de um contato mais próximo com autores e idéias com os quais tive contato no final da graduação e que traziam uma reflexão bastante crítica do sistema educacional brasileiro.

Nessa mesma época comecei a lecionar em faculdades particulares, tendo me dedicado especialmente ao ensino de Metodologia Científica e Psicologia Geral, abordando nesta última os conteúdos de História da Psicologia, pois não havia tal disciplina nos currículos destes cursos. Desde que me formei, praticamente nunca deixei de trabalhar com estes conteúdos e considero esse trabalho como talvez uma das principais fontes de aprendizagem e aprofundamento destes temas, sendo que o contato com os alunos foi um dos principais canais de interlocução das minhas atividades de pesquisa.

No curso das disciplinas do mestrado tive a oportunidade de tomar contato e aprofundar discussões com diversas idéias filosóficas e sociológicas, assim como com a crítica à Psicologia e muitas de suas influências na Educação. Estas idéias, calcadas, sobretudo, no materialismo Histórico e Dialético, privilegiavam, por seus pressupostos, a necessidade da compreensão histórica; esse veio analítico fazia-se presente na maioria das disciplinas, mas em "História da Educação Brasileira" ele se concretizava mais radicalmente, tentando aprofundar a compreensão histórica da educação no país e nas relações que se estabeleciam entre esta e os fatores econômicos, políticos, sociais e culturais.

Esta disciplina veio mudar o que eu pensava da História até então. Desvelava-se para mim a possibilidade da História poder constituir-se numa disciplina viva sobre coisas vivas. Comecei a conhecer um pouco da História do Brasil e, principalmente, dei-me conta da impossibilidade de compreensão da realidade brasileira sem o conhecimento de sua história. O mesmo poderia ser dito em relação à Educação. Foi, todavia, no estudo da História da Educação Brasileira que me deparei com inúmeros elementos que sugeriam a História da Psicologia no Brasil; mais precisamente o desenvolvimento das idéias escolanovistas e as tentativas de sua implantação no país mostravam nitidamente a influência das teorias psicológicas, a implementação de algumas de suas técnicas principalmente a psicometria - e a ampliação da difusão de seus conteúdos. 
Embora devesse ser óbvio, dei-me conta que trabalhava com História da Psicologia, mas nunca tivera a preocupação com sua história específica no Brasil.

Esse momento coincidiu com a necessidade de elaboração do projeto de pesquisa para o mestrado. Muitas idéias e temas competiam para esse fim, porém, este fato então recente facilitou a decisão. Decidi-me por estudar as relações entre as idéias escolanovistas e a constituição da Psicologia no Brasil, enfocando especificamente a contribuição de Lourenço Filho. A dificuldade de localização dos materiais necessários ao trabalho e a escassez de tempo levaram-me, porém, a adiar este projeto, reservando-o para o doutorado. Mantendo-me, no entanto, na finalidade de buscar articular o pensamento escolanovista e a Psicologia, decidi-me por desenvolver um trabalho que tivera sua origem na graduação, qual seja: o estudo do Sistema Educacional e da Psicologia em Maria Montessori.

Nesse processo, descobri que a História da Psicologia no Brasil era um campo fértil e rico e, no entanto, praticamente intocado. Poucos trabalhos existiam a esse respeito: Lourenço Filho, Annita Cabral, Isaías Pessotti, Samuel Pfromm Neto e Antonio Gomes Penna eram autores dos poucos artigos disponíveis na época. Marina Massimi, Regina Helena de Freitas Campos e Iris Goulart ainda não haviam concluído seus primeiros trabalhos. Já no doutorado, conheci os trabalhos de Marina Massimi e Regina Helena de Freitas Campos, que me foram fundamentais, não apenas no sentido de reforçar minha opção, mas como experiências teóricometodológicas bem-sucedidas. Deveu-se esse contato fundamentalmente à professora Maria do Carmo Guedes, que orientou minha tese de doutoramento.

O projeto original, acima citado, objetivava enfocar a atuação de Lourenço Filho. Entretanto, fazia-se necessário compor o quadro histórico no qual sua produção estivesse organicamente inserida. Logo no início da pesquisa, esta necessidade estabelecida a priori acabou por tornar-se a própria pesquisa. Esse período da história e, sobretudo, seus antecedentes haviam sido muito pouco estudados e explorados; os "fatos" encontravamse meramente citados e organizados em seqüência cronológica; poucos estudiosos, com exceção de Antonio Gomes Penna, haviam se debruçado sobre a produção da Psicologia nessa época. 
Impunha-se, pois, pela opção metodológica assumida - que não se limitava a uma perspectiva internalista na abordagem do objeto de estudo, mas no entendimento de que era também necessário compreendê-lo na sua historicidade -, a tentativa de melhor compor o quadro mais amplo em que Lourenço Filho, o escolanovismo e a Psicologia se inseriam. Buscava-se, em última instância, a composição de um quadro, cujas peças estavam em geral soltas, perdidas, escondidas ou misturadas.

A composição desse quadro iniciou-se a partir dos poucos trabalhos sobre a História da Psicologia no Brasil; alguns estudos sobre a História da Medicina - particularmente a Medicina Social e a Psiquiatria -, em número e qualidade relativamente superiores ao que havia sobre a Psicologia; os estudos, em profusão, sobre a História da Educação Brasileira e obras de História do Brasil. Por esse caminho, principalmente, cheguei a muitas das fontes primárias com as quais trabalhei.

Nessa busca, cujo percurso foi difícil, frustrante e, ao mesmo tempo, apaixonante, constituiu-se o trabalho que apresentei como tese de doutorado: O processo de autonomização da Psicologia no Brasil1890/1930: uma contribuição aos estudos em História da Psicologia.

Foi difícil, porque as fontes não estavam disponíveis; era necessário partir de indícios, muitas vezes precários, para se chegar a elas; certamente há muitas fontes ainda não identificadas que precisam sê-lo. Frustrante, porque muitas obras são já consideradas quase que definitivamente perdidas; a preservação da memória não é realmente um traço de nossa cultura. Apaixonante, por inúmeros motivos; como Marina Massimi, encontrei autores e obras de grande originalidade e atualidade, com Ulysses Pernambucano e principalmente Manoel Bomfim; deparei-me com fatos, obras e autores nunca antes imaginados da maneira como eram; mudou profundamente e ampliou-se minha compreensão da Psicologia, do Brasil e, particularmente, da Psicologia no Brasil.

A afirmação da Psicologia e, sobretudo, da História da Psicologia no Brasil foi a decorrência mais importante desse trabalho. Ao mesmo tempo em que ficava cada vez mais nítida a opção por trabalhar nessa área do conhecimento, vinha também a clareza de sua relevância acadêmica e social. Explicitava-se que a compreensão da Psicologia implicava necessariamente no conhecimento de sua história; em outras palavras, ficava nítido que o entendimento do presente exige a consideração de seu 
processo histórico de construção, assim como seus projetos para o futuro implicam no reconhecimento profundo do presente e seus determinantes.

Na seqüência, debrucei-me sobre a obra de Manoel Bomfim, este autor banido da memória do pensamento brasileiro e só muito recentemente resgatado como talvez um dos mais brilhantes intelectuais deste país. Tenho-me detido particularmente em suas obras educacionais e psicológicas, em que o fenômeno psíquico é por ele concebido como eminentemente histórico-social, mediatizado pela linguagem e portador de uma complexidade que só pode ser apreendida no estudo da obra humana ao longo da história. A expectativa desse trabalho é restituir-lhe a vida, resgatando-o para a memória da Psicologia brasileira e tentar compreender os motivos de seu "esquecimento".

Paralelamente, tenho me dedicado ao ensino da História da Psicologia no Brasil e me empenhado na divulgação de seus conteúdos. Creio mesmo que se poderia falar em militância, cujo objetivo é fundamentalmente socializar conhecimentos, ainda que reconhecidamente precários, com vistas a contribuir com a consolidação dessa área de conhecimento e, de maneira esperançosa e talvez pouco modesta, estimular novos pesquisadores a dedicarem-se a esta temática.

Não posso negar que me considero privilegiada, quando releio o que acabei de escrever e entrevejo os caminhos por que passei. Fatores que podem ser considerados conjunturais, como ter crescido numa farmácia "antiga", ter sido aluna de professores que faziam de seu trabalho docente também uma maneira de participar ativamente de seu tempo, foram condições fundamentais para minha formação. Por outro lado, elementos mais diretos; como a ênfase na pesquisa e o contato com idéias e teorias comprometidas com determinadas concepções de Psicologia e Educação e, particularmente, com a afirmação de sua historicidade, deram as bases para minha formação, embora esta não esteja e nem jamais poderá estar acabada;, assim como a leitura histórica, a formação do pesquisador (em verdade, toda e qualquer formação) será sempre incompleta, inacabada e passível de superação. 


\title{
Em busca de um modelo teórico para o estudo da História da Psicologia no contexto sociocultural
}

\author{
Regina Helena de Freitas Campos*
}

O interesse pelo estudo da história da Psicologia me foi despertado nos anos 70. Tive o privilégio de trabalhar, no Curso de Pós-graduação em Educação da Universidade Federal de Minas Gerais, com um grupo de pesquisadores extremamente críticos em relação aos efeitos negativos que a aplicação indiscriminada dos conceitos e procedimentos de intervenção elaborados pela Psicologia Científica vinha provocando nos modernos sistemas de ensino de massa. Estudos críticos vinham demonstrando que conceitos psicológicos, quando utilizados na avaliação das características emocionais ou intelectuais de grandes grupos humanos, podiam provocar a estigmatização do ou discriminação daqueles que não se adequassem à norma do grupo (Kamin, 1974; Bisseret, 1974).

As críticas focalizavam, especialmente, o desconhecimento, por parte dos psicólogos, dos efeitos sociopolíticos das classificações e diagnósticos por eles realizados; a falta de sensibilidade dos instrumentos de medida psicológica a questões socioculturais; e, finalmente, o prejuízo objetivo que a aplicação desses instrumentos vinha causando a grupos e estratos sociais culturalmente marginalizados ou oprimidos. Para mim, questionavam a imagem da Psicologia como uma disciplina científica progressista, dedicada a compreender e contribuir para solucionar problemas relacionados à diversificada e complexa experiência humana.

A partir dessa preocupação é que se construiu minha trajetória como estudiosa da história da Psicologia Científica. Parti em busca de uma perspectiva externalista, que tornasse possível compreender as complexas relações entre a produção teórica em Psicologia e o contexto sociocultural.

\footnotetext{
* Universidade Federal de Minas Gerais.
} 


\section{A pesquisa em história da psicologia}

Sob a orientação segura do sociólogo Oder José dos Santos, comecei a pesquisar como surgiu, nas escolas primárias mineiras, a demanda pela utilização de conceitos psicológicos. Na época, a teoria que parecia mais apropriada para descrever o processo de institucionalização do sistema de ensino brasileiro era a teoria da reprodução (Bourdieu e Passeron, 1975). A partir da perspectiva reprodutivista, a aplicação de procedimentos derivados das teorias psicológicas nas escolas podia ser pensada como um dos vários mecanismos destinados a reproduzir a estrutura do sistema de ensino, garantindo, assim, a própria reprodução cultural. Ora, se essa estrutura era baseada na desigualdade social, também a psicologia funcionaria de acordo com a lógica da produção e reprodução dessa desigualdade por meio da reprodução da desigualdade cultural. Assim, a psicologia científica poderia ser interpretada como parte da superestrutura ideológica, cuja finalidade era, como a de qualquer ideologia, tornar pouco transparentes os mecanismos da reprodução social por intermédio da legitimação da desigualdade com argumentos pretensamente universais e neutros.

Meu primeiro trabalho em História da Psicologia, a dissertação de mestrado intitulada Psicologia e ideologia - Um estudo da formação da psicologia educacional em Minas Gerais (Campos, 1980), defendida em setembro de 1980, adotava a perspectiva reprodutivista. A primeira parte do estudo analisa os textos da reforma de ensino de 1928, em Minas Gerais, visando evidenciar as relações entre a lógica da ideologia liberal e a introdução da perspectiva meritocrática, por meio dos testes de inteligência. A segunda parte resulta de pesquisa das primeiras publicações em Psicologia na Revista do Ensino e outros periódicos da época, e descreve relatos de pesquisas realizadas na década de 30 sobre o desenvolvimento mental das crianças de Belo Horizonte pela psicóloga russa Helena Antipoff, que instituiu o primeiro laboratório de Psicologia no Estado. São também relatadas as iniciativas de Antipoff visando o atendimento clínico e a reeducação de crianças carentes, abandonadas e/ou excepcionais, por meio da criação da Sociedade Pestalozzi de Minas Gerais. Na terceira parte, o significado da classificação das crianças em normais e excepcionais é examinado, à luz da literatura sociológica. A interpretação adotada visava demonstrar que os conceitos e procedimentos propostos pela Psicologia Científica resultavam na confirmação empírica dos pressupostos da 
ideologia liberal - oportunidades iguais para todos, a cada um conforme as possibilidades de sua natureza.

A dissertação foi muito bem recebida nos meios acadêmicos, por propor uma interpretação critica da aplicação da psicologia ao sistema de ensino, ainda pouco divulgada. Pouco depois, Maria Helena Patto publicava em São Paulo o livro Psicologia e ideologia - Uma introdução crítica à psicologia escolar (Patto, 1984), que contém estudo histórico-crítico das teorias da carência e da marginalidade cultural e dos programas de educação compensatória e propõe as abordagens psicanalítica e da psicologia institucional como mais apropriadas para compreender os efeitos psicológicos da exclusão social. Outros trabalhos de análise dos movimentos de higiene mental no Brasil (Costa, 1976, 1979; Machado et al, 1978) também contribuíram para redirecionar a interpretação acerca da aplicação da Psicologia Científica em direção a uma perspectiva critica, na qual as questões socioculturais não fossem traduzidas na linguagem do déficit cognitivo ou lingüístico.

A expansão dessa perspectiva e a busca de novos modelos de interpretação evidenciavam, naquele momento, a existência de pelo menos duas abordagens em psicologia: uma delas voltada predominantemente para a legitimação da exclusão social com base na psicotécnica, e outra voltada para a reinterpretação dos chamados déficits cognitivos em termos da dinâmica sociocultural e da situação de opressão.

A existência dessas duas vertentes de pensamento contraditórias mostrava que a teoria reprodutivista não era suficiente para dar conta da complexidade da história da Psicologia. Nem todas as idéias psicológicas podiam ser analisadas como contribuições à dominação e à reprodução das relações sociais hegemônicas, visto que havia claramente uma vertente contra-hegemônica que visava justamente trabalhar pelo rompimento da lógica excludente.

Foi a partir deste entendimento que iniciei o trabalho de crítica à perspectiva reprodutivista. Em 1982, ingressei no programa de Doutorado da Universidade de Stanford, EUA, buscando uma nova perspectiva teórica que me permitisse dar conta dessa aparente “anomalia”, no sentido proposto por Kuhn (1989), no desenvolvimento da Psicologia Científica. Uma questão, sobretudo, preocupava-me, desde a época em que redigi a dissertação de mestrado: o trabalho de Helena Antipoff tinha, já na década 
de 30, características contra-hegemônicas, evidenciadas, sobretudo, em sua preocupação com a influência da cultura no desenvolvimento cognitivo e nas iniciativas visando criar condições para a educação dos chamados “excepcionais sociais”, ou seja, crianças que fracassavam nas escolas públicas mineiras. Como interpretar essa tendência? A teoria da reprodução não fornecia a resposta para esta indagação.

\section{A contribuição da história da cultura e da história social}

Foi no trabalho de historiadores da cultura e nos textos de história social que propunham a revisão da historiografia tradicional a partir da perspectiva dos excluídos que encontrei algumas das respostas que procurava.

Para Huizinga, a história cultural trata simultaneamente dos modos de vida ("patterns of life”), da arte e do pensamento, ou seja, das relações de interdeterminação entre esses três domínios de ação e de reflexão. O trabalho do historiador seria o de encontrar os elementos que os unem e a rede de significados expressos em cada um deles, buscando configurar um padrão cultural que evidenciasse sua pertinência a um determinado tempo e lugar. Contrário ao evolucionismo, Huizinga se aproxima da perspectiva do relativismo cultural de Boas e Benedict, por exemplo, que focaliza exatamente a lógica subjacente que atravessa diversos momentos e aspectos da vida social, configurando um padrão de cultura que só se torna inteligível ao observador se os elementos forem tomados em seu conjunto. Como em uma sinfonia, a mesma melodia é interpretada por diferentes instrumentos e em diferentes tonalidades, mas é o resultado do conjunto que importa. Huizinga insiste também na necessidade de o historiador praticar uma certa imersão no passado que evoca, procurando re-experienciar o contexto que procura reconstruir (Huizinga, 1960). Ao mesmo tempo, a cultura é definida como um conjunto de crenças e ideais que o grupo social busca incessantemente tornar reais, mas que são, ao mesmo tempo, desmentidos pela realidade. Essa dinâmica entre ideal e realidade é que forjaria o movimento cultural e a emergência de novas formas de vida, crenças e valores (Huizinga,1954).

Já a história social, com sua ênfase na reconstrução das práticas sociais e seu papel na determinação dos rumos da história, abria novas perspectivas de interpretação das evidências. Thompson (1966, 1976), por 
exemplo, pensava que a leitura historiográfica deveria ser feita de baixo para cima, isto é, from below. Era uma espécie de retomada da tradição marxista, que também havia operado um deslocamento de perspectiva: "repensar a relação entre a práxis e a poiésis do ângulo dos trabalhadores" (Konder, 1992, p. 103). Mais que isto, essa tradição reconhece a atividade humana de criação e transformação da realidade:

a práxis é a atividade concreta pela qual os sujeitos humanos se afirmam no mundo, modificando a realidade objetiva e, para poderem alterá-la, transformando-se a si mesmos. É a ação que, para se aprofundar de maneira mais conseqüente, precisa da reflexão, do auto-questionamento, da teoria; e é a teoria que remete à ação, que enfrenta o desafio de verificar seus acenos e desacenos, cotejando-os com a prática. (Konder, 1992, p. 115)

Enfim, a história deve ser a história da práxis, e por isso deve recuperar a atividade humana no convívio social, pois é ai que a história se faz.

É verdade que a organização da produção, nas sociedades de classe, tende a alienar o sujeito, instituindo uma clivagem entre teoria e prática, reificando a força transformadora da atividade do trabalho. Mas isto não significa que deixe de existir a resistência à alienação. A práxis tem uma dimensão instrumental, mecânica, mas também uma dimensão existencial, criativa: “a práxis, na concepção de Marx, não se limitou a unir a theoria e a poiésis, pois envolvia também - necessariamente - a atividade política do cidadão, sua participação nos debates e nas deliberações da comunidade, suas atitudes na relação com outros cidadãos, a ação moral, intersubjetiva. Envolvia, em suma, aquilo que os antigos gregos chamavam de práxis" (Konder, 1992, p. 128). É justamente essa atividade política, imanente ao cotidiano, que inclui a própria resistência à dominação, às limitações à liberdade, que vai ser buscada pela história “vista de baixo”.

Partindo de rigorosa crítica ao determinismo estruturalista, que tendia a contar uma história sem sujeito, desenrolando-se a partir do jogo das grandes estruturas, essa perspectiva buscava recuperar o papel da ação humana e, por via de conseqüência, do indeterminado na história. Era preciso superar a tendência então hegemônica na historiografia de um excessivo dedutivismo, que levava a interpretações sempre repetitivas. Não era preciso pesquisar: já sabíamos, de antemão, para onde caminhava o 
movimento da sociedade, nosso papel era apenas ilustrar e confirmar esse movimento da reprodução, com evidências retiradas de textos e falas das elites dirigentes.

David Tyack, meu professor, em Stanford, trabalhando sobre a história social da educação norte-americana (Tyack, 1974), lembrava que era preciso prestar atenção ao inesperado na história. Assim teríamos acesso à mudança, à transformação. Da mesma forma, para mim a perspectiva teórica em Psicologia elaborada por Helena Antipoff nos anos 30 parecia inesperada, tendo em vista a evidente tendência das elites brasileiras da época em buscar a reprodução do sistema social desigual e excludente pelo uso de medidas psicológicas cegas à diversidade cultural.

Os novos historiadores da Psicologia, com, sua ênfase nas relações entre diferentes concepções sobre a natureza humana, visões de mundo e contribuições teóricas, também muito me ajudaram. A história crítica da Psicologia se fazia em duas direções: por um lado, buscava-se desmistificar as teorias psicológicas, mostrando suas raízes ideológicas e suas relações com os valores hegemônicos. De outro, uma perspectiva contextualiza procurava reconstruir a psicologia como ciência do indivíduo em seu contexto histórico, sócio-econômico e cultural (Montero, 1996).

Karier (1986), por exemplo, via a evolução da Psicologia Científica como resultando da progressiva secularização da cultura ocidental e da própria condição humana. Ao se desligar da Filosofia, no final do século XIX, a Psicologia viria a se constituir, segundo Karier, em uma espécie de núcleo de produção de visões de mundo. A visão teológica do século XIX viria a ser progressivamente substituída pela visão psicológica do século $\mathrm{XX}$.

Nas palavras de Karier:

At the heart of the oppressed condition within the religious community was the issue of human deviation and the problem of "sin". At the center of the oppressed condition and human deviation within the psychological community was "sickness". The techniques (...) are all essentially the techniques of human control. (p. 337)

Era como se a Psicologia viesse a fornecer os instrumentos práticos necessários para se lidar com a cultura secularizada da sociedade industrial. Sokal (1984) comentava que "a social history of psychology can reveal the 
ways in which psychological ideas originated, developed and changed through time, and influenced the world in which they emerged” (p. 307), defendendo a necessidade de uma abordagem externalista à história da psicologia.

Essa abordagem externalista requer a atenção ao jogo de contradições nas práticas sociais e também nas idéias. Em vez de tratar a Psicologia em um sentido evolutivo, como a construção progressiva de sínteses teóricoexperimentais cada vez mais precisas (como queriam os historiadores internalistas), era preciso localizar os conflitos e as contradições entre teorias. A literatura sobre a história da psicologia e da psiquiatria no Brasil, por exemplo, tendia a confundir a eugenia com o movimento da higiene mental. Outros trabalhos, contudo, mostravam que o movimento eugênico, a higiene mental e mesmo o movimento de orientação infantil (childguidance) eram tendências diferenciadas e relativamente autônomas e, mais importante, com pressupostos teóricos diversos. Enquanto a higiene mental enfatizava a prevenção de distúrbios psicológicos por meio da educação e modificação de condições ambientais, a eugenia pretendia erradicar a doença mental por intermédio da manipulação genética ou de medidas sugeridas pelo darwinismo social, como a esterilização dos doentes (Spaulding \& Balch, 1983). Além disso, a discussão sobre o uso de testes de QI, pelo menos nos EUA, deixou de ser apenas acadêmica e invadiu os tribunais e a sociedade civil (Kamin, 1974; Cronbach, 1975; Reschly, 1981), o que despertou o interesse acadêmico e produziu uma série de excelentes estudos sobre a história das medidas das capacidades intelectuais (Gould, 1981; Evans \& Waites, 1981; Chapman, 1979; Sutherland, 1984; Napoli, 1981 e muitos outros).

Mas como estudar a história vista "de baixo"? Como construir as evidências a serem utilizadas no argumento? A respeito da história, aprendi muito com Richard Morse. Estudioso da história intelectual da América Latina, escreveu, em 1978, um estudo comparado sobre a relação entre ciência e contexto cultural em 1978 (Manchester Economics and Paulista Sociology), no qual sugere que "intellect takes effective grasp of social issues only when it feels itself in easy, affective communion with the traditions of a national or cultural community” (p. 7). Tanto Manchester, em torno de 1820, quanto São Paulo, um século depois, conheceram fortes surtos de industrialização acompanhados de desorganização urbana, grande crescimento populacional, distúrbios sociais. 
Contudo, na Inglaterra as pressões do industrialismo e do novo proletariado provocaram propostas de soluções que, dada a longa tradição inglesa - "all shared the image of a coherent national society persisting through time" (p. 11) -, a idéia de que todos faziam parte desta mesma sociedade, e que soluções deviam ser buscadas para todos. As soluções então propostas pela Escola de Economia de Manchester eram, sobretudo, produtos do senso comum de industrialistas práticos, informadas por princípios empiristas e utilitaristas; não houve um verdadeiro esforço de teorização. Em São Paulo, ao contrário, uma tradição nacional era quase inexistente, e o que existia era a memória de uma polarização social ainda mais profunda, a escravidão, e a fragmentação política.

Assim, o aparecimento de uma imaginação sociológica em São Paulo, nos anos 50, seria a manifestação tardia de uma espécie de "prise de conscience" sobre a nação, uma busca de identidade cultural que já se anunciava nos modernistas da década de 20. Mas a institucionalização do estudo e da pesquisa sociológica a partir dos anos 30, com a fundação da Escola Livre de Sociologia e Política, da Faculdade de Filosofia, Ciências e Letras da USP, e do Departamento de Cultura da Prefeitura de São Paulo (dirigido por Mário de Andrade), trouxe novos elementos: influências vindas do exterior, estudantes oriundos das classes médias. As teorias trazidas pelos professores franceses e norte-americanos não respondiam adequadamente às questões locais, a agenda das elites (industrialização e modernização) se transformou nas mãos de estudantes que não estavam necessariamente comprometidos com ela.

O trabalho de Morse é importantíssimo em sua discussão sobre a hegemonia de certas idéias, por evidenciar como a elaboração intelectual depende do que ele chama de uma combinação de cognição e afeto, ou seja, um compromisso com o fenômeno estudado. No caso da Inglaterra, a ausência de uma síntese sociológica é explicada em função da tradição empirista/utilitarista, aliada a uma tendência das elites de escolher as soluções de compromisso para prevenir revoluções. No caso brasileiro, a ausência de tradição intelectual sólida, aliada ao mal-estar com a fragmentação da sociedade, tornou possível a criação de uma sociologia crítica: "Paulista sociologists eventually managed to adumbrate comprehensive - even loosely 'revolutionary' - diagnoses under the noses and at the expense of elite patrons” (p. 28). A invenção, a criação do conhecimento seria concomitante a uma trajetória que vai da heteronomia 
(a submissão a modelos externos) à autonomia (consciência crítica baseada em modelos criados a partir da realidade vivida). $\mathrm{O}$ aspecto crucial aqui é o senso de comunidade, isto é, o consenso, seja enraizado em conhecimentos ou em ideais comuns.

\section{A antropologia histórica}

Estudos em antropologia histórica também foram importantes. Estudei com Renato Rosaldo, em Stanford, que havia desenvolvido o argumento, contrário ao funcionalismo a-histórico tradicional em etnografia, de que "ethnography stands to gain considerable analytical power through close attention to historical process" (Rosaldo, 1980). Seu trabalho com os Ilongots, povo caçador de cabeças que vive nas Filipinas, havia mostrado que os estudos sincrônicos das sociedades "primitivas" tendiam a criar a ilusão da "sociedade sem história", cara à Antropologia moderna (Wolf, 1982). Rosaldo começa o livro com a biografia de um etnógrafo norte-americano, William Jones, que havia estudado os Ilongots no início do século, tendo sido assassinado por eles ao fim de sua expedição. No texto, a ambivalência de Jones em relação aos Ilongots - ora admirados como um raro exemplar de vida selvagem, ora detestados em sua bestialidade - é analisada tendo por referência a formação anterior do antropólogo, nascido em Oklahoma, e tendo convivido amplamente com parentes índios em sua juventude. Essa "biografia contextualizada" sugeriume um modelo para o estudo da história da Psicologia: a biografia do autor como fonte para compreender a relação entre sua visão de mundo - e, por extensão, da visão de mundo de sua classe e de sua época e lugar - e o trabalho teórico.

Mas, voltando à teoria da história, a crítica se dirigia exatamente aos pressupostos da homogeneidade e da continuidade das culturas, que seriam equivalentes, em Antropologia, à visão estática e conservadora de Durkheim sobre a sociedade. A sensibilidade para a história do grupo levou Rosaldo, naturalmente, aos historiadores-etnógrafos, como Ladurie (1979), e a mim também, por meio dele. O texto de Rosaldo também me chamou a atenção pelo conteúdo de autocrítica: também ele, como eu, percebia erros de interpretação em sua tese (de doutorado), que foi escrita na perspectiva sincrônica. Certos fatos observados em sincronia - as lutas traumáticas que acompanhavam o divórcio, por exemplo, que ele primeiro tomou por um 
traço cultural, mais tarde, analisadas de uma perspectiva diacrônica, revelaram-se a expressão de realinhamentos políticos datados. A observação estrutural torna-se, assim, um ponto de partida para verificar em que medida as estruturas sociais atuam tanto no sentido de facilitar quanto de constranger a ação humana. Essa dialética entre estrutura e ação também me interessou, pois na história das idéias pode-se observar o mesmo movimento de reprodução/criação de novos modos de ver o mundo.

Ao mesmo tempo, Rosaldo observava que, para cada processo, diferentes interpretações emergiam, para concluir que "conflicts of interpretation derive from people's location within the deeper divergences of local political life” (p. 20). Esta compreensão era crucial para meu projeto. Rosaldo havia observado em uma sociedade mais simples - cuja ordem hierárquica era organizada apenas pelas estruturas de idade e sexo um processo que certamente ocorre em sociedades complexas e plurais, mas que é mais difícil de observar. Geertz (com quem Rosaldo havia estudado em Harvard) já havia chamado a atenção para a concepção de cultura como rede de significados atribuídos pelo grupo. Rosaldo agora acrescentava a observação de que esses significados não são necessariamente compartilhados, mas disputados pelos grupos em conflito. O movimento entre estruturas pré-formadas e atividade humana pressupõe, por parte do narrador, atenção ao momento e à totalidade, isto é, à interação entre estruturas e eventos. Seu objetivo é

to delineate as fully as possible the complex orchestration among events, institutions and ideas as they unfold together through time (...) to stress not just the given nature of society, but also the ways in which human beings continually construct, manipulate, and even recast the social worlds imo which they were bom and within which they will die. (Rosaldo, 1980, p. 23)

A questão fundamental, para o narrador, era, portanto: o que as pessoas estão lutando para fazer acontecer?

Social life - viewed as a forward-looking struggle among alternative courses of action that certain structures both enable to be and limit begins to emerge not as the inevitable playing out of underlying principies, but rather as a complex interplay of political processes. (idem, p. 22) 
Segundo Davis (1984), a contribuição da Antropologia aos estudos históricos pode ser caracterizada por levar a sério o ponto de vista e os costumes de povos e culturas muito diferentes da nossa. Isto é válido também para a história das ciências, e da psicologia em particular. Se queremos compreender como a psicologia foi recebida e interpretada pelas professoras primárias no Brasil dos anos 30, temos que nos armar com a sensibilidade e desarmar idéias preconcebidas, sob pena de corrermos o risco de simplesmente afirmar que elas não entenderam, ou não tinham formação para entender, as complicações da teoria psicológica. Claro que a história é bem mais complexa e exige, portanto, que o historiador faça o esforço do antropólogo, para se tornar um insider em uma cultura estranha.

Geertz também tem o que dizer sobre o assunto, ao sugerir que, do ponto de vista antropológico, "if you want to understand what a science is, you should look in the first instance not at its theories or its findings, and certainly not at what its apologists say about it; you should look at what the practitioners of it do" (p. 5).

\section{Conclusão: história da psicologia no contexto sociocultural}

Assim, com base nessa visão histórica e antropológica, e convencida de que a história da psicologia científica constitui importante documento acerca do movimento cultural do século XX, focalizei o desenvolvimento da psicologia educacional no Brasil no contexto das políticas educacionais dos anos 20 e 30. Para descrever o contexto, parti do pressuposto segundo o qual, nas modernas sociedades industriais, as escolas são instituições contraditórias. Se, por um lado, se apresentam à sociedade como veículos de abertura de oportunidades de ascensão social, por outro lado, é-lhes atribuída também a função de reprodução da divisão social do trabalho (Carnoy, 1984). São instituições submetidas a pressões contraditórias. Para as crianças e suas famílias, devem contribuir para desenvolver o potencial dos alunos e abrir-lhes chances de sucesso profissional. Para os administradores e planejadores educacionais, devem ser eficientes em sua função de orientar os estudantes para ocuparem os lugares disponíveis na escala social de ocupações. Todas essas demandas, ao atravessar a prática escolar, incidiriam também sobre cada setor específico de atividade da instituição. A dedução lógica desse esquema de análise era que essas 
tendências contraditórias poderiam também ser encontradas na teoria e na prática da psicologia educacional.

Para verificar essa hipótese, organizei o estudo a partir da obra dos dois pioneiros da psicologia educacional no Brasil: Lourenço Filho e Helena Antipoff. Ambos eram os únicos psicólogos em atividade no Brasil citados por Murchinson em seu Psychological register (Murchinson, 1929). Ambos haviam desenvolvido, no Brasil, instrumentos de medida da capacidade intelectual das crianças amplamente utilizados nas escolas elementares: os testes ABC (Lourenço Filho, 1957) e a adaptação do BinetSimon (Antipoff, 1931).

Mas havia diferenças importantes em cada trajetória. Antipoff era de origem russa, havia estudado em Paris (no Laboratório Binet-Simon) e em Genebra, com Claparede. Entre 1916 e 1924, esteve na Rússia novamente, participando ativamente do processo de reconstrução da educação no país após a Primeira Grande Guerra e a Revolução de 1917 (Antipoff, 1975). Ao chegar ao Brasil a convite do governo mineiro, em 1929, trazia em sua bagagem uma visão democrática do papel político da educação popular. Já Lourenço Filho, ativo participante do movimento dos pioneiros da Escola Nova no Brasil, trazia consigo uma visão, comum às elites brasileiras, de que a escola elementar deveria exercer um papel seletivo no país, de ao mesmo tempo civilizar a população e selecionar as elites dirigentes (Lourenço Filho).

O desenvolvimento da Psicologia Científica mostrava que, desde o início do século $\mathrm{XX}$, as teorias da inteligência se dividiam em três tendências. A primeira, apriorista, considerava que as habilidades intelectuais seriam parte do patrimônio genético individual e transmitidas hereditariamente. A segunda vertente, ambientalista, considerava a inteligência como o produto do impacto do meio sobre o aparato cognitivo humano. A terceira, interacionista, concebia a inteligência como o resultado da ação do indivíduo sobre o ambiente. Nesta abordagem, é a estrutura das estratégias de solução de problemas práticos que, uma vez internalizada, constitui a estrutura do pensamento inteligente (Piaget, 1948). A vertente sociointeracionista acrescentava a idéia de que o movimento de internalização dessas estratégias de resolução de problemas e o aprendizado da linguagem traziam consigo a internalização da própria cultura (Vygotsky, 1978). 
Cada uma dessas visões alternativas oferecia prescrições diferenciadas, ou mesmo contraditórias, para a prática educativa. Enquanto a abordagem hereditária sustentava que pouco podem fazer os educadores para transformar ou melhorar o patrimônio genético individual, tanto a abordagem ambientalista quanto a interacionista propunham que as habilidades intelectuais podem ser modificadas com sucesso pela educação.

A questão era saber se existiria correspondência entre cada uma dessas visões da inteligência e diferentes concepções do papel da escola na sociedade. A visão hereditária poderia corresponder a um modelo seletivo, no qual as escolas são vistas como agências cujo papel é selecionar e discriminar os estudantes, de acordo com suas capacidades intelectuais, para diferentes ocupações. As perspectivas ambientalista e interacionista corresponderiam a um modelo mais democrático, no qual as escolas seriam vistas como responsáveis pelo desenvolvimento das capacidades cognitivas dos estudantes.

Para verificar se essa correspondência se verificava na prática, ou seja, se a ação do contexto sociocultural e de diferentes grupos sociais em conflito seria constitutiva da própria elaboração das hipóteses da Psicologia Científica, acompanhei a introdução dos procedimentos de medida da inteligência no sistema educativo no âmbito do movimento de reforma escolar, entre 1920 e 1940. As reformas, realizadas sob a liderança de educadores progressistas, visavam expandir o número de matrículas e desenvolver valores cívicos e nacionalistas em parcelas amplas da população (Fletcher, 1983; O’Neil, 1975). Foram, mais que simples reformas, a verdadeira institucionalização de um sistema público de ensino no país (Paiva, 1973). A expansão das matrículas, sobretudo em áreas urbanas, é que forçou as escolas a receber números crescentes de estudantes oriundos da classe trabalhadora, criados em condições de extrema pobreza. Essas crianças não apresentavam, ao entrar para a escola, as habilidades intelectuais requeridas para o trabalho acadêmico. Neste contexto é que os testes psicológicos foram introduzidos nas escolas. Esperava-se que os psicólogos fornecessem os meios científicos de lidar com a diversidade cultural e intelectual da população de estudantes. Acompanhei também como as demandas por escolarização se expressavam no discurso das famílias, buscando nessas demandas e em sua lógica a correspondência com as propostas da Psicologia. A perspectiva inatista privilegiava os grupos cuja socialização primária já os colocava em contato com a cultura escolar. 
Já as propostas ambientalistas se coadunavam com um modelo democrático, presente nas demandas das classes populares, que depositavam nas escolas a esperança do acesso ao saber hegemônico. Na época, já se observava o problema do fracasso de grande número de crianças das classes populares na escola primária.

Duas diferentes orientações teóricas prevaleceram, entre os psicólogos que tentavam explicar o fracasso dos estudantes na escola primária. A primeira abordagem, exemplificada no trabalho de Lourenço Filho, enfatizava o papel de fatores psicobiológicos na definição do potencial intelectual das crianças. Nesta concepção, o potencial intelectual era considerado como sendo geneticamente definido e desenvolvido por maturação (Lourenço Filho, 1957). A segunda abordagem, exemplificada no trabalho de Helena Antipoff (1931), enfatizava a ação do meio ambiente sociocultural no desenvolvimento da capacidade intelectual. O conceito de “inteligência civilizada”, proposto por Antipoff, foi construído sobre a suposição de que as habilidades intelectuais requeridas para uma experiência de aprendizagem escolar bem-sucedida eram adquiridas precisamente na interação da criança com seu ambiente físico e cultural, no processo de socialização primária. Esta abordagem, construtivista, também defendia que o processo de escolarização era um poderoso meio de desenvolver as habilidades mentais nas crianças.

A despeito dessas diferenças, ambos os autores apresentavam algumas similaridades ao enfrentar o problema da aplicação da psicologia à educação. Ambos compartilhavam a fé na ciência para resolver os problemas das escolas e acreditavam que a homogeneização das classes por nível intelectual poderia contribuir para tornar mais fácil o trabalho com crianças de diferentes níveis de inteligência. Para Lourenço Filho, as dificuldades dos estudantes provinham principalmente de sua imaturidade para o aprendizado. Assim, os estudantes deveriam ser agrupados por nível de maturidade. Já para Antipoff, as dificuldades estariam ligadas à falta de “inteligência civilizada”, isto é, das habilidades culturalmente adquiridas para o aprendizado acadêmico. Assim, as crianças deveriam ser agrupadas por nível de desenvolvimento mental e submetidas a diferentes programas de estudo.

Os efeitos da adoção da homogeneização das classes foram observados por meio de um estudo de caso do sistema público de ensino de 
Belo Horizonte nos anos 30. As altas taxas de repetência previamente observadas permaneceram nos mesmos patamares, isto é, em torno de 53\% para a primeira série primária, diminuindo progressivamente nas séries subseqüentes. As escolas adotaram uma explicação eclética para o fenômeno. Em geral, pensava-se que as dificuldades das crianças em seguir o programa de ensino decorriam da falta de habilidades intelectuais. Estas eram consideradas como decorrendo tanto de fatores genéticos quanto ambientais. A falta de habilidades intelectuais decorrente da hereditariedade era considerada uma "fatalidade biológica", enquanto a falta de estimulação ambiental apropriada durante o período pré-escolar era considerada uma "fatalidade social". Em ambos os casos, pensava-se que pouco poderia ser feito pelas escolas para modificar o nível mental das crianças, a menos que uma professora "especialmente dedicada" decidisse fazê-lo. A ênfase colocada pelas autoridades educacionais no papel da professora especialmente dedicada, presente inclusive no texto do Regulamento do Ensino Primário de 1928, evidencia que, em certa medida, elementos de uma orientação construtivista também estavam presentes na abordagem predominante do problema do fracasso escolar.

As escolas públicas, no entanto, ofereciam poucas oportunidades para aquelas professoras "especialmente dedicadas" cumprirem sua tarefa. Trabalhando com recursos escassos e submetidas a um sistema de tomada de decisões altamente centralizado, as professoras tinham pouco controle sobre seu próprio processo de trabalho. No nível organizacional, a adoção da homogeneização das classes tornou-se um meio prático de lidar com a diversidade sociocultural da população escolar. No nível ideológico, ela forneceu um meio de racionalizar e justificar a impossibilidade das escolas de superar os níveis previamente definidos de desenvolvimento mental das crianças.

Para compor com mais rigor o quadro do contexto em que ocorreu a adoção das medidas psicológicas no sistema público de ensino e seguindo as recomendações da antropologia histórica, procurei observar também as reações das famílias e do pessoal das escolas aos modelos da Psicologia, por meio de fontes publicadas e não publicadas. Encontrei material riquíssimo para esta análise em publicações de associações de professores primários e em diários inéditos que localizei no acervo do Centro de Documentação e Pesquisa Helena Antipoff. 
Verifiquei, enfim, que a discussão sobre a relação entre capacidade intelectual e sucesso escolar tocava em um tema central da dinâmica das políticas educacionais: a questão da igualdade de oportunidades. Pareceume que a solução encontrada pelas escolas públicas atendia muito mais às elites que aos trabalhadores. Creio ter podido, assim, reconstruir a história da Psicologia no contexto: ao buscar os pontos de vista de diferentes grupos envolvidos no debate, pude compreender como foi montada, no Brasil, a "máquina de produzir repetentes" que até hoje está em funcionamento no sistema público de ensino e o papel da Psicologia neste processo.

O exame da experiência educativa da Fazenda do Rosário, na qual a abordagem construtivista foi adotada de modo mais completo na educação e re-educação de crianças de classe popular que fracassavam nas escolas comuns, mostrou que a adoção dessa abordagem requeria condições que não estavam presentes nas escolas públicas. O modelo da Fazenda do Rosário incluía um sistema de tomada de decisões mais democrático, no qual tanto professores quanto estudantes usufruíam de maior autonomia. Além disso, as professoras compartilhavam de um espírito religioso, derivado do catolicismo social, no qual o desenvolvimento da capacidade intelectual das crianças era visto como um dever humanitário. Esta associação entre democracia, autonomia e senso de dever (ou, nas palavras de Morse, entre cognição e afeto), precisamente, não estava presente nas escolas comuns, dificultando o desenvolvimento de uma consciência crítica acerca da exclusão das crianças de classe popular dos benefícios da escolarização. Ou seja, as evidências indicavam que a Psicologia Científica expressou, no momento de sua introdução no sistema escolar brasileiro, visões contraditórias sobre a natureza humana e sobre a relação entre capacidade intelectual e sucesso escolar presentes na própria formação social brasileira (Campos, 1989).

Este modelo de análise tem sido por nós aplicado a outras esferas da reflexão teórica em psicologia. O desenvolvimento da psicanálise no Brasil, por exemplo, parece ter seguido o mesmo padrão contraditório verificado no caso da psicologia da inteligência (Campos, 1991).

Atualmente, o modelo tem servido de referência para a implantação da linha de pesquisa em História da Psicologia e Contexto Sociocultural no Curso de Pós-graduação em Psicologia da Universidade Federal de Minas Gerais. 


\section{Referências}

ANTIPOFF, D. (1975). Helena Antipoff Sua Vida, Sua Obra. Rio de Janeiro, José Olympio Ed.

ANTIPOFF, H. (1931). "O Desenvolvimento Mental das Crianças de Belo Horizonte”. In: Boletim 7, Belo Horizonte, Secretaria de Educação e Saúde Pública.

BISSERET, N. (1974). "L’Idéologie des Aptitudes Naturelles”. In: Les Inégaux et la Sélection Universitaire. Paris, Presses Universitaires de France.

BOURDIEU, P. \& PASSERON, J.C. (1975). A Reprodução. Rio de Janeiro, Francisco Alves.

CAMPOS, R.H.E (1980). Psicologia e Ideologia: Um Estudo da Formação da Psicologia Educacional em Minas Gerais. Belo Horizonte, Faculdade de Educação da UFMG, (dissertação de mestrado).

. (1989). Conflicting Interpretations of Intellectual Abilities Among Brazilian Psychologists and Their Impact on Primary Schooling. Stanford, CA, Stanford University, (PhD dissertation).

(1991). Contexto sócio-cultural e tendências da Pedagogia Psicanalítica na Europa Central e no Brasil (1900-1940). Belo Horizonte, Faculdade de Filosofia e Ciências Humanas da UFMG.

CARNOY, M. \& LEVIN, H. (1984). Schooling and Work in the Democratic State. Stanford, Stanford Univ. Press.

CHAPMAN, P. D. (1979). Schools as Sorters: Lewis M. Terman and the Intelligence Testing Movement. Stanford, CA, Stanford University, $\mathrm{PhD}$ dissertation.

CHURCH, R. L. (1971). "Educational Psychology and Social Reform in the Progressive Erà. In: History of Education Quarterly, Winter.

COSTA, J. F. (1976). História da Psiquiatria no Brasil. Rio de Janeiro, Documentário.

(1979). Ordem Médica e Norma Familiar. Rio de Janeiro, Graal. CRONBACH, L. (1975). "Five decades of public controversy over mental testing”. In: American Psychologist 30(1), Jan.

EVANS, B. \& WAITES, B. (1981). I.Q. and mental testing: an unnatural science and its social history. Adantic Highlands, N.J., Humanities Press.

FLETCHER, P. (1984). Mass Education as a State Legitimation Agency. Stanford, CA, Stanford University, (PhD dissertation). 
GOULD, S. J. (1981). The Mismeasure of Man. New York, WWNorton. HUIZINGA, J. (1960). "The task of Cultural History". In: HUIZINGA, J. Men and Ideas, Essays. London, Meridien Books. . (1954). The Waning of the Middle Ages. New York, Anchor Books.

KAMIN, L.J. (1974). The Science and Politics of IQ. New York, John Wiley and Sons.

KARIER, C. (1986). Scientists of the Mind: Intellectual Founders of Modern Psychology. Chicago, Univ. of Illinois Press.

KONDER, L. (1992). “A Filosofia da Praxis”. In: KONDER, L. O Futuro da Filosofia da Praxis (O Pensamento de Marx: no Século XXI). Rio de Janeiro, Paz e Terra, 2a. ed.

KUHN, T. S. (1989). A Estrutura das Revoluções Científicas. São Paulo, Perspectiva.

LOURENÇO FILHO, M.B. (s/d). Juazeiro do Padre Cícero. São Paulo, Melhoramentos.

(1957). Testes ABC. São Paulo, Melhoramentos, $6^{\text {a }}$.edição.

MACHADO, R., LOUREIRO, A., LUZ, R. \& MURICY, K. (1978). Danação da Norma: Medicina Social e Constituição da Psiquiatria no Brasil. Rio de Janeiro, Graal.

MONTERO, M. (1996). "Paradigmas, Corriemes y Tendencias de la Psicología Social Finisecular”. In: Psicologia e Sociedade 8 (1): 10219, jan./jun.

MURCHISON, C. (Ed.) (1929). The Psychological Register. Worcester, Mass., Clark University Press.

NAPOLI, D. (1981). Architects of Adjustment: the History of the Psychological Profession in the US. London, Kennikat Press.

O'NEIL, Charles F. (1975). The Search for Order and Progress: Brazilian Mass Education 1915-1935. PhD dissertation, University of Texas at Austin.

PAIVA, V.P. (1973). Educação Popular e Educação de Adultos. São Paulo, Loyola.

PATTO, M.H.S. (1984). Psicologia e Ideologia - Uma Introdução Crítica à Psicologia Escolar. São Paulo, T:A.Queiroz.

PIAGET, J. (1948). La Naissance de l'Intelligence chez l'Enfant. Neuchâtel, Délâchaux et Niestlé, $2^{\mathrm{a}}$. ed. 
RESCHLY, D. J. (1981). "Psychological Testing in Educational Classiflcation and Placement”. In: American Psychologist 36(10):1094-102, October.

ROSALDO, R. (1980). Ilongot Headhunting 1883-1974 - A Study in Society and History. Stanford, Ca., Stanford Univ. Press.

SOKAL, M. M. (1983). "James McKeen Cattel and American Psychology in the 1920s”. In: BROŽEK, J. (Ed.) Explorations in the History of Psychology in the U.S.. Cranbury, N.J., Associated Univ. Presses, 273-323.

SUTHERLAND, G. (1984). Ability, Merit and Measurement: Mental Testing and English Education 1880-1940. New York, Oxford Univ. Press.

THOMPSON, E.P. (1966). The Making of the English Working Class. New York, Vintage Books.

. (1976). Whigs and Hunters: The Origin of the Black Act. New York, Pantheon Books.

VYGOTSKY; L. S. (1978). Mind in Society. Cambridge, Mass., Harvard University Press.

WOLF, E. (1982). Europe and the Peoples Without History. Berkeley, CA, University of California Press.

\section{Bibliografia}

BLOCK, N.J. \& DWORKIN, G. (Eds.) (1976). The IQ Controversy. New York, Random House.

BROŽEK, J. (Ed.). (1984). Exploratiom in the History of Psychology in The United States. Cranbury, N.J.: Associated Universities Presses, Inc. (Ed.) (1980). Historiography of Modern Psychology. Toronto, C.J . Hogrefe, Inc.

COHEN, S. (1983). "The Mental Hygiene Movement, me Development of Personality and the School: the Medicalization of American Education”. In: History of Education Quarterly 23(2), Summer.

DAVIS, N. Z. (1984). “Anthropology and the possibilities of the past”. In: Princeton Univ., unpublished.

GEERTZ, C. (1973). “Thick Description: Toward ao Interpretive Theory of Culture”. In: GEERTZ, C. The Interpretation of Cultures.

LADURIE, E. (1979). Montaillou: The Promised Land of Error. New York, Vintage Books. 
LAKATOS, L (1989). La Metodologia de los Programas de Investigación Científica. Madrid, Alianza Ed.

MORSE, R M. (1988). O Espelho de Próspero: Cultura e Idéias nas Américas. São Paulo, Companhia das Letras.

. (1978). "Manchester Economics and Paulista Sociology”. In: Stanford Journal of International Studies 13, Spring.

MURPHY, G. (1932). A Historical Introduction to Modern Psychology. New York, Hartcourt, Brace \& Co.

POPPER, K. (1993). A Lógica da Pesquisa Científica. São Paulo, Cultrix.

SCHWARZ, R. (1973). “As Idéias Fora do Lugar”. In: Estudos Cebrap 3(149).

SPAULDING, J. \& BALCH, P. (1983). “A Brief History of Primary Prevention in the Twentieth Century: 1908 to 1980”. In: American Journal of Community Psychology 11(1):59-80.

TYACK, D. B. (1976). "Ways of Seeing: An Essay on the History of Compulsory Schooling”. In: Harvard Educational Review 46(3), August.

. (1974). The One Best System: a History of American Urban Education. Cambridge, Harvard University Press. 
PARTE III

O ensino da história da psicologia 


\title{
História da Psicologia para curso de graduação
}

\author{
William B. Gomes *
}

A formação em psicologia é um tema apaixonante e desafiador. A psicologia é um campo de conhecimento de múltiplas formações. As ênfases e preferências variam de curso para curso sem que isto signifique, necessariamente, uma opção por área, aplicação ou metodologia. Tal variedade, se de um lado enriquece o estudo desta ciência e profissão, de outro traz desafios que devem ser diagnosticados e equacionados. Como professores dos cursos de pós-graduação temos um compromisso ético com a qualificação profissional por meio da formação de docentes e da atualização de disciplinas da graduação. Pessoalmente, sinto-me muito atraído por propostas de ensino que contemplem os avanços da ciência, sua pluralidade e sua história. Neste texto, identificarei alguns desafios que o pluralismo acarreta aos currículos dos cursos de graduação e indicarei como o estudo da história da psicologia pode, simultaneamente, esclarecer a diferença e a identidade que nos congregam, neste grande campo de pesquisa e aplicação. Em outras palavras, estarei argumentando que a história é um modo atrativo e eficiente de introdução conceitual e metodológico à psicologia. Os caminhos e descaminhos da história ilustram a emoção e a aventura de se fazer ciência, clarificam raízes conceituais e identificam matrizes que servem como metateorias reguladoras.

Além disso, desvelam os desafios sociais que serviram para estimular ou inibir o desenvolvimento de teorias e práticas nos diversos períodos históricos.

\section{Pluralismo conceitual da psicologia}

O currículo do curso de graduação em Psicologia, em uso desde 1962, pode ser considerado como um modelo clássico de formação em Psicologia. Contempla as diferentes áreas e ainda destina quantidade considerável de tempo para a iniciação aplicada, por meio dos estágios. Incertezas de mercado têm incentivado a defesa de uma formação

* Pós-graduação em Psicologia, Universidade Federal do Rio Grande do Sul. 
generalista, baseada em dois argumentos: 1) manter a abertura e a abrangência, e 2) propiciar maiores possibilidades de trabalho. Por outro lado, a ordenação progressiva dos conteúdos é problemática. É difícil decidir o que é introdutório e básico; o que é intermediário, diferenciador ou integrador; e o que é terminal e profissionalizante. Na verdade, a logicidade está implícita na seriação curricular. Na prática, assiste-se à peregrinação de determinados conteúdos de disciplina em disciplina, à omissão de outros, à apresentação de fundamentos que parecem não fundamentar coisa alguma e à formação em práticas que carecem de fundamentos.

Neste quadro problemático, os conteúdos são apresentados como que descontextualizados de sua etimologia e historicidade. Um bom exemplo é o uso de termos ou vocábulos em psicologia. Sabe-se que as teorias identificam-se com diferentes conceitos, ocorrendo muitas vezes o uso de um mesmo termo para diferentes definições. Lamenta-se, contudo, que este vasto vocabulário, extremamente importante, incorpore-se aos iniciantes sem que haja uma clareza de seu significado e de sua etimologia. Não temos uma literatura didática preparada para a formação em psicologia, como ocorre em outros países. Mesmo entre autores é pouco usual a preocupação com a definição dos termos ou conceitos que sustentam seus argumentos, mesmo tratando-se de palavras com muitas definições e sentidos. O estudo da história da psicologia aliado a uma taxonomia conceitual parece-me uma boa maneira de promover uma iniciação científica e profissional que enfatize as diferenças e identidades e as relações e contrastes entre teorias. Com estes objetivos assumi em 1989 a disciplina de História da Psicologia no primeiro semestre do Curso de Graduação.

\section{Pluralismo psicológico e história da psicologia}

$\mathrm{Na}$ minha avaliação, a primeira necessidade para o sucesso da proposta era a definição de um fio condutor, que ao mesmo tempo unificasse a seqüência dos períodos históricos e permitisse a demarcação de suas diferenças (continuidade versus ruptura). A solução veio da Filosofia da Ciência. Operacionalizei cada item do programa desde os gregos até a revolução cognitiva em quatro perguntas básicas: o que eu sei, como eu sei, por que eu sei e para quê eu sei. Estas perguntas permitem identificar, em 
cada época ou em cada teoria, o que se sabe (objeto), como se sabe (episteme), qual a justificativa para o que se sabe (lógica) e quais as implicações deste saber (ética). As quatro perguntas nos remetem para as quatro grandes áreas da filosofia e para os quatro passos importante da descoberta e comunicação científica.

As quatro grandes divisões da filosofia são: metafísica, epistemologia, lógica e axiologia. Vejamos, a seguir, a definição destas regiões filosóficas (de acordo com Ferrater-Mora, 1988 e Lanigan, 1988) e como podem ajudar no ensino da psicologia em cursos de graduação por meio da história.

A metafísica divide-se usualmente em ontologia, que se ocupa de questões referentes aos vários tipos de entidades que compõem o universo, e em metafísica propriamente, que se ocupa com a descrição das várias formas de realidade. No caso da disciplina História da Psicologia as perguntas ontológicas são: o que é psicologia? qual o objeto da psicologia? ou ainda, qual a natureza deste objeto? As perguntas levam à definição de uma ou várias entidades e conseqüentemente à justificação de sua natureza.

A epistemologia refere-se aos modos de aquisição do conhecimento e aos critérios de validação desde conhecimento. Em geral, entende-se como epistemologia a preocupação com a consistência entre a definição de um objeto e o meio de acesso a este objeto. As teorias de epistemologia são comum ente associadas às teorias de metodologia. Conhecer um objeto implica num reconhecimento de origem, numa organização e numa possibilidade de verificação. O método por sua vez exige fatualidade, localização, definição e avaliação. No caso da disciplina História da Psicologia as perguntas epistemológicas podem ser colocadas da seguinte forma: em sendo este o objeto da psicologia, seu modo de acesso é este, através deste meio, justificado deste modo.

A lógica estuda as formas do pensar corretamente. Tradicionalmente, estuda-se lógica examinando-se as relações entre as premissas e as suas conclusões. Na disciplina História da Psicologia não se estuda lógica aristoteliana nem lógica moderna. O interesse é a identificação e a compreensão do tipo de argumento a que uma determinada teoria recorre para justificar as relações entre suas premissas e suas conclusões. No entanto, um conhecimento preliminar de lógica seria muito útil. 
Por fim, a axiologia ocupa-se da estética e da ética. Ocupa-se do exame dos valores humanos e de suas formas de expressão e simbolização. É nesta região que se encontram as aplicações ou recomendações práticas das teorias.

As mesmas quatro perguntas já mencionadas indicam os quatro passos da descoberta científica: qual o problema (objeto), qual o encaminhamento (episteme), qual o critério de análise e verificação (lógica), e quais as implicações dos achados para a prática e para a ciência (ética).

O programa da disciplina inicia com a História das Idéias para identificar nelas a idéia de uma psicologia nascente. A primeira preocupação é a demarcação de conceitos psicológicos básicos, tais como consciência, alma (psique), animismo, comportamento, objetividade, racionalidade, identidade, dialética, atomismo, mecanicismo, elementos, temperamento, subjetividade, reminiscências (nativismo), causalidade e hedonismo (egoísta e racional). Com a continuidade do programa, novos termos ou novas definições para termos já conhecidos vão surgindo da história. Um aspecto interessante deste exercício é tratar, à distância, de problemas muito próximos, como as relações entre teoria e ideologia (ideologia como valor regulador subjacente à teoria). Sabe-se que a explicitação de uma metateoria subjacente que regula uma teoria popular pode provocar uma forte polêmica entre grupos favoráveis e contrários. Tal polêmica pode confundir a organização do trabalho de classe e inviabilizar o exame crítico necessário para a formação. É comum ouvir comentários de que a discussão estava bem interessante até ser colocada uma questão que produziu uma grande polêmica. Daí em diante os trabalhos seguem bem tumultuados e lá pelas tantas ninguém parece saber do que se fala. Este é um exemplo de uso improdutivo de tempo de aula.

Uma maneira de ilustrar esta proposta de introdução histórica à psicologia é tomar a definição ontológica do que é psiquismo para diferentes autores, em diferentes épocas. Pode-se começar com as versões de Platão e Aristóteles, seguir com releitura destas versões em Agostinho e Tomás de Aquino, passar pelos racionalistas e empiristas e finalizar o exercício com o idealismo de Kant. Em cada caso, identifica-se qual a preocupação maior que regulava as preocupações menores. Por exemplo, Platão partia de um entendimento de vida psíquica procedente de uma alma 
reencarnável, incorpórea, essencialmente moral; Aristóteles, de um princípio de vida animal independente, mas com uma função de coordenação geral; Agostinho de uma alma reencarnável graças às dádivas do Criador; e Aquino advinda de uma alma imaterial, mas unida ao corpo e dirigida ao mundo natural (Gomes, 1990).

Neste quadro comparativo, discute-se como as tradições dos autores e suas prioridades orientavam as formulações gerais da teoria. Por exemplo, Platão vinha de uma tradição socrática, e seu trabalho buscava conferir um status ontológico à posição de Sócrates, de que a alma é essencialmente moral (Mueller, 1968); Aristóteles buscava fundamentar a definição de uma realidade estável e harmoniosa, na qual as partes eram coordenadas pelo conjunto. Uma outra diferença era que Platão desenvolvia uma metodologia e lógica para o estudo da astronomia; e Aristóteles aplicava sua metodologia e lógica para o estudo da natureza. Já Agostinho e Aquino vão reler os gregos Platão e Aristóteles, respectivamente, na ótica cristã e desta forma procuram manter a tradição dos filósofos que os inspiraram, mas com os ajustes necessários para adaptá-la à fé cristã.

O mesmo exercício pode ser realizado na história moderna fazendo a pergunta: o que é vida psíquica para Descartes, Locke, Hume e Kant? O contexto está modificado pelas mudanças gerais do tempo, entre elas, a valorização da individualidade e a substituição da certeza divina pela dúvida metodológica. Infelizmente, o espaço não me permite continuar com o exercício. De qualquer modo, o exercício facilita a compreensão do que é um objeto para uma ciência e as implicações decorrentes das escolhas. Também mostra que a situação especialíssima da relação exclusiva/inclusiva de sujeito e objeto em psicologia não deve ser motivo de lamentações ou prantos. Deve ser vista na formação multifacetada deste corpo de conhecimento chamado psicologia, fruto das muitas tendências que germinaram nos séculos XVIII e XIX, e de outras tendências que se articularam no século XX. Tal condição aponta para grandes regiões ontológicas em psicologia, com implicações específicas para epistemologia, lógica e ética. Basta comparar as propostas de psicologia de autores contemporâneos como Wundt e Ebbinghaus (empírica e experimental) e Brentano e Dilthey (empírica e descritiva) e suas conseqüências: o desenvolvimento de uma psicologia como ciência natural, no primeiro caso, e de uma psicologia como ciência humana, no segundo (Giorgi, 1970). Estas posições estavam sendo influenciadas por grandes teorias, como a 
física de Newton (o mecanicismo e elementarismo de Wundt) e os neokantianos das escolas de Banden e Marburg (as diferenças entre ciências nomotéticas e idiográficas e definição omológica de objeto como algo que se constrói). A seguir, o furacão darwiniano vai influenciar várias vertentes funcionalistas da psicologia (Figueiredo, 1989). Lembre-se, novamente, da leitura cristã da filosofia grega, recupere o fio condutor, mantendo presente o viés da disciplina (a preferência do professor).

O empreendimento científico requer desenvolvimentos instrumentais e analíticos que viabilizam ou impedem a descoberta, quando não levam a outras descobertas por puro acidente. A história está repleta destes casos. Assim, pode-se dizer que a ciência é um jogo competitivo com vitórias e derrotas. Mostra-se este jogo trazendo o problema produzido pelo desenvolvimento histórico de uma teoria que passa a fazer novas exigências, como, por exemplo, entender que a psicologia deve ser estudada no laboratório e não em nível puramente teórico. Tem-se então uma seqüiência de experimentos que se diferenciam gradativamente, na tentativa de resolver as relações entre objetividade e subjetividade. Foram estudos que procuravam compatibilizar um objeto definido por uma tradição filosófica (o cartesianismo), com um modo de conhecer decorrente da exigência metodológica da física e da fisiologia. O mesmo pode-se fazer com uma revisão histórica do método experimental para o estudo da memória inaugurado por Ebbinghaus, ou do método dos tipos ideais proposto por Spranger para o estudo da personalidade (Wolman, 1960). Curiosamente, quando se inicia o projeto de Psicologia Fenomenológica na Duquesne University, Estados Unidos, o primeiro estudo experimental foi uma variação do experimento clássico de Ebbinghaus (Colaizzi, 1971). Procuro com este exercício manter presentes a crítica e a abertura para uma psicologia de muitas possibilidades ontológicas e epistemológicas. As questões da prática psicológica são tratadas como decorrências de escolha ou implicações éticas.

A proposta pode parecer ambiciosa e extensa para um semestre. Na verdade, críticas vêm surgindo nesta direção, e a Comissão de Coordenação do Curso de Psicologia estuda a possibilidade de ampliar a disciplina para dois semestres. A mudança seria interessante para poder tratar de um lado as teorias e sistemas e do outro a historiografia propriamente. Por outro lado, alunos dos últimos semestres manifestam interesse em poder revisitar a História da Psicologia, agora com mais conhecimento e experiência. 
Algumas vezes foi possível sincronizar as disciplinas de História da Psicologia e Psicologia Experimental I. O programa de Psicologia Experimental I voltava-se para o estudo de experimentos clássicos em psicologia, nos vários sistemas teóricos. Assim, quando se discutia o papel histórico do experimento de Pavlov (1927) ou Tolman (1948), esses experimentos de alguma forma eram revividos nas aulas de Experimental. Hoje, programas computadorizados simulam muitos experimentos clássicos em psicologia facilitando a compreensão e o respeito por esta importante tradição em psicologia (vide a Revista Teaching Psychology). O mesmo pode ser feito com as tradições descritivas e interpretativas. Além disso, o planejamento criterioso do cronograma e das atividades didáticas faz uma diferença no uso do tempo e no aproveitamento geral da disciplina.

Nos primeiros anos em que lecionei a disciplina, o item "História da Psicologia no Brasil" era a última parte do programa. A disciplina encerrava com a história da regulamentação da profissão e o reconhecimento do Curso de Psicologia no Brasil, em 1962. Atualmente, inclui informações sobre a psicologia no Brasil no momento em que elas aconteceram, no curso da história. Por exemplo, quando a psicologia se iniciava na Alemanha, o que acontecia de psicologia no Brasil? Temos como exemplo teses escritas nas faculdades de medicina da Bahia e do Rio de Janeiro. Outro exemplo, quando se fala em autores importantes como William James, Charles Darwin, Sigmund Freud, indica-se que notícias se tem do trabalho destes autores repercutindo no Brasil. James e Darwin visitaram o Brasil e escrevem impressões sobre o novo e exótico país (sobre Darwin, vide Desmond e Moore, 1995, pp. 137-138; sobre James, vide Feinstein, 1984, capítulo II - Vacation in Brazil pp. 169-181). Os trabalhos de Freud começaram a repercutir em nosso país desde 1899 nas aulas do professor Juliano Moreira na Faculdade de Medicina da Bahia, e o próprio Freud correspondeu-se com psicanalistas brasileiros, como foi o caso de Durval Marcondes em 1926 (Perestrello, 1988). Em outras palavras, assim como se fala dos desenvolvimentos da psicologia na Alemanha, Inglaterra, França, Rússia e Estados Unidos, fala-se igualmente no Brasil.

\section{Cuidados complementares}

O lugar da produção científica é também valorizado na disciplina. Indica-se como a ciência saiu da clandestinidade e passou a ocupar um 
espaço privilegiado na universidade. Descreve-se brevemente o modelo de universidade implantado na Alemanha em 1810 e que serviu de exemplo para as universidades modernas. O exemplo foi seguindo, de alguma forma, pela Inglaterra em 1819 e mais decididamente pelos Estados Unidos em 1876. A nova universidade caracterizava-se no apoio à pesquisa, no oferecimento de boas condições de trabalho (entenda-se laboratórios), no respeito à liberdade acadêmica e na remuneração adequada aos professores (Hearnshaw, 1987). É importante mencionar que a formação universitária começava na graduação e terminava com a tese de doutorado. Mostra-se, a seguir, que no Brasil tivemos inicialmente as pesquisas relacionadas às teses de doutoramento, trabalho apresentado ao final ou logo após o curso de graduação. No entanto, estas teses deixaram de ser uma exigência e foram extinguindo-se lentamente. Na década de 40, por exemplo, já eram raras as defesas de tese nas faculdades de medicina. A pesquisa volta a ganhar apoio no Brasil com a organização do CNPq e Capes, nos fins da década de 40 e início da década de 50. Outro impulso importante foi a reorganização da pós-graduação no início da década de 70 . Aproveita-se para dizer que o Brasil conta com uma estrutura muito bem organizada de pós-graduação, coordenada pela Capes. No entanto, alerta-se para a expansão de uma pós-graduação fortemente anunciada pela mídia (entendase marketing) em geral conveniada com escolas estrangeiras e oferecidas no Brasil por entidades sem perfil acadêmico ou mesmo técnico-profissional.

\section{Palavras finais}

Por fim, quero saudar o trabalho do Grupo de História da Psicologia nesta ANPEPP e desejar a ele muito sucesso. A preocupação com a história mostra a maturidade e a consolidação da Psicologia no Brasil. Trabalhos recentes em História da Psicologia no Brasil (Campos, 1992, Centofanti, 1982; Massimi, 1990; Penna, 1985; e Pessotti, 1988) permitem um melhor conhecimento do nosso passado e abrem novas perspectivas para a nossa compreensão da psicologia. São informações e interpretações que esclarecem nossa leitura das influências européias e norte-americanas, ajudam a entender as repercussões da psicologia no Brasil em diferentes épocas e identificam as contribuições da psicologia produzida no Brasil. Afinal, o Brasil foi um dos primeiros países a reconhecer a psicologia como profissão. A tarefa da proposta apresentada é justamente levar estas contribuições para o Curso de Graduação. 


\section{Referências}

CAMPOS, R. H. F. (1992). "Notas para uma história das idéias psicológicas em Minas Gerais”. In: Conselho Regional de Psicologia/4 $4^{a}$ Região (Org.) Psicologia: Possíveis olhares outros fazeres (pp. 11-63). Belo Horizonte, CRP/4 $4^{a}$ (MG/ES).

CENTOFANTI, R. (1982). "Radecki e a psicologia no Brasil”. In: Psicologia: Ciência e Profissão, 3(1), 3-50.

COLAIZZI, P. F. (1971). "Analysis of the learners perception of learning material at various phases of a learning process”. In: A. Giorgi, W F. Fischer \& R. von Eckartsberg (Eds.), Duquesne studies in phenomenological psychology: Volume 1. Pittsburgh, Duquesne University Press.

DESMOND, A. \& MOORE, J. (1995). Darwin: A vida de um evolucionista atormentado (H. dos Santos, G. Pereira \& S. Kakovicz, Trads.). São Paulo, Editora Geração Editorial.

FEINSTEIN, H. M. (1984). Becoming William James. Ithaca, NY, Cornell University Press.

FERRATER MORA, J. (1988). Dicionário de filosofia (4 vols). Madrid: Alianza Editorial

FIGUEIREDO, L. C. M. (1989). Matrizes do pensamento psicológico. Petrópolis, Vozes.

GIORGI, A. (1970). Psychology as human science: A phenomenologically based approach. New York, Harper \& Row. Tradução brasileira (1978). Psicologia como ciência humana: Uma abordagem de base fenomenológica (Riva S. Schwartzman, Trad.). Belo Horizonte, Interlivros.

GOMES, W (1990). “O papel crítico da epistemologia na formação do pesquisador”. Simpósio. In: Anais do III Simpósio Brasileiro de Pesquisa e Intercâmbio científico, da ANPEPP em Águas de São Pedro de 26 a 30 de agosto, pp. 29-41.

LANIGAN, R. (1988). Phenomenology of communication. Pittsburgh, PA.: Duquesne University Press.

LOURENÇO FILHO, M. D. (1971). “A psicologia no Brasil”. In: Arq.Bras. Psic. Apl. 23(3), 113-142. (Publicado originalmente em 1954).

MASSIMI, M. (1990). História da psicologia brasileira. São Paulo, EPU. 
MUELLER, F. L. (1968). “História da psicologia” (L. L. de Oliveira, M. A. Blandy \& J. B Damasco Penna). São Paulo, Companhia Editora Nacional/Editora da USP.

PAVLOV; I. P. (1927). Conditioned reflexes (G. V. Anrep, Trad.). London, Oxford University Press.

PENNA, A. G. (1985). História da psicologia: Apontamentos sobre as fontes e sobre algumas das figuras mais expressivas da psicologia na cidade do Rio de Janeiro. Rio de Janeiro, Editora da Fundação Getúlio Vargas.

PERESTRELLO, M. (1988). "Primeiros encontros com a psicanálise. Os precursores no Brasil (1899-1937)”. In: S. A. Figueira (Org.) Efeito Psi: A influência da psicanálise. Rio de Janeiro, Editora Campus.

PESSOTTI, I. (1988). “Notas para uma história da psicologia brasileira”. In: Conselho Federal de Psicologia (Org.) Quem é o psicólogo brasileiro? São Paulo, Edicon.

TOLMAN, E. C. (1948). "Cognitive maps in rats and men”. In: Psychological Review, 55, 189-208.

WOLMAN, B. J. (1960). Contemporary theories and systems in psychology. New York, Harper \& Row. 


\title{
História da Psicologia: recurso para formação de pesquisadores e de psicólogos
}

\author{
Maria do Carmo Guedes*
}

História da Psicologia é uma área pouco desenvolvida no país. Entretanto, poupo os leitores quanto aos números ou qualquer outro tipo de argumentação que sustente tal afirmativa - porque não pretendo aqui fazer a defesa da necessidade de desenvolvê-la, seja como área de pesquisa, seja como disciplina da graduação ou pós-graduação. Em que pese minha total crença na importância dessa necessidade, a afirmação com que inicio este texto é apenas um ponto de partida, de dois em que me apóio para participar desta coletânea em História da Psicologia.

A segunda assertiva em que me baseio não precisa prova, nem mesmo explicação. Por razão diferente: trata-se de poesia. É um verso que empresto de René Char, um poeta francês contemporâneo que afirma: "O fruto é cego, é a arvore que vê”.

Juntas, estas assertivas resumem bem o quadro de contingências que nos fizeram assumir atividades de ensino em História da Psicologia e o modo como nos desincumbimos dessa tarefa.

Permito-me relatar aqui três experiências nas quais a História da Psicologia tem sido nosso objeto de trabalho como professora universitária: a $1^{\text {a }}$ - quando se criou um "Núcleo de Estudos em História da Psicologia” no Pós-Graduação da PUC-SP, com a intenção de aproximar pesquisadores que nos ajudassem a dar conta da necessidade de fazer nossos doutorandos em Psicologia Social, boa parte dos quais oriundos de outras áreas que não a Psicologia, a melhor contextualizarem seus projetos de tese; a $2^{\mathrm{a}}$ - que mostra como a História da Psicologia foi um recurso para aproximar estudantes de uma instituição criada com o objetivo de incentivar alunos da graduação a pesquisar; finalmente, a $3^{\mathrm{a}}$ um curso que deu créditos em pesquisa a estudantes da pós-graduação em Psicologia da Educação.

* Pós-graduação em Psicologia Social e da Educação - PUC-SP. 
Um pouco distantes no tempo, uma da outra, estas experiências compõem um total de doze anos de administração de contingências no ensino em história da psicologia. Uma administração voltada sempre para a formação em pesquisa, e nas mais diversas abordagens, da História e da Psicologia.

Este relato é feito, pois, com a intenção de partilhar experiências de ensino, mas também de tecer algumas considerações sobre o que pude aprender com este jeito de abordar a História da Psicologia (HP). É esta a minha pesquisa hoje nesta área: recolhendo depoimentos de nossos estudantes de iniciação científica, trabalhos e relatórios de mestrandos e doutorandos, pareceres de assessores das agências financiadoras de bolsas e auxílios obtidos por nós e nossos estudantes, bem como impressões de colegas que, como nós, se preocupam com a área e sua importância na formação do psicólogo e do pesquisador em Psicologia ${ }^{1}$, temos hoje um rico material em análise, realizada sempre como parte de nossos estudos sobre ensino de pesquisa. Aqui, o que se propõe é o relato das experiências acima referidas, com o objetivo de contribuir para uma área que, no mínimo, está a precisar de muito cuidado para que a árvore continue produzindo e sendo acolhedora - nossa maneira de contribuir para a História da Psicologia, se é que se permite aqui alguém que está mais para jardineiro ${ }^{2}$ que para pesquisador ou mesmo professor.

\section{O Núcleo de Estudos em História da Psicologia}

A PUC-SP tem uma certa tradição em HP. Talvez porque o professor Enzo Azzi, responsável pela instalação do Instituto de Psicologia dessa Universidade, tenha vindo da Itália. Não deve ser difícil alguém se interessar por história quando se vive ou viveu em meio a tanta manifestação de passado longínquo. Ou quando, deslocado de sua terra, alguém tem que rapidamente se adaptar a uma outra. A Revista de Psicologia Normal e Patológica, que doutor Azzi dirigiu por quase vinte

\footnotetext{
${ }^{1}$ Refiro-me aqui ao Grupo de Trabalho da ANPEPP sobre Iniciação Científica, coordenado pela professora Lívia Simão Mathias (USP) e do qual fazem parte ainda Sergio Leite (Unicamp), Lígia Marcondes (USP) e Maria Margarida P. Rodrigues (UFES).

2 Adicionalmente às manifestações mais pessoais e que, em geral, refletem mais o carinho dos autores que a importância do nosso trabalho, foi significativo para o Núcleo a referência feita por Marina Massimi em sua Tese de Doutorado, USP, 1985.
} 
anos, tinha uma seção - “Crônicas e Documentação” - que mostra bem seu compromisso com a História. Aniela Ginsberg é outro exemplo entre nós: o cuidado em registrar sua participação em congressos mostra sua atilada percepção da importância em documentar fatos, eventos. Finalmente, cabe lembrar que o primeiro currículo de formação do psicólogo da antiga FFCL São Bento tinha a História da Psicologia como disciplina obrigatória, com quatro horas semanais desde o primeiro ano do curso.

Entretanto, quando em 1982/3 foi criado o doutorado em Psicologia Social e quisemos colocar História da Psicologia como crédito obrigatório para nossos alunos, não encontramos na PUC, nem em nenhuma outra universidade de São Paulo, quem quisesse ou pudesse assumir a disciplina. Havia duas condições: o título de doutor e uma pesquisa em andamento na área (afinal, era uma disciplina para doutorandos). Maria Fernanda Beirão, que tinha sido professora de HP no Curso de Graduação por muitos anos, cumpria a primeira condição, mas não a segunda. Luis Cláudio Figueiredo, que na ocasião relia Wundt ${ }^{3}$, nem por isso tratava a história como um objeto de pesquisa; seu interesse era, se posso assim me exprimir, circunstancial. Não que isto não baste para dar aula para doutorandos, mas nossa idéia é que esta disciplina deveria, futuramente, tornar-se uma linha de pesquisa. E quanto mais ficava claro que não iríamos encontrar alguém, mais se fortalecia em nós a importância de conquistar nossos doutorandos para a preocupação que nos animava: conhecer HP é indispensável para situar corretamente um problema de pesquisa em Psicologia.

A solução foi criar um Núcleo de Estudos, o Nehpsi - um pouco mais tarde Niehpsi, para sinalizar que se tratava de um núcleo interinstitucional ${ }^{4}$ -, que visava aproximar de nosso Programa os poucos pesquisadores que íamos encontrando, qualquer que fosse sua titulação (e até sem nenhuma), qualquer que fosse sua abordagem, qualquer que fosse seu particular objeto

\footnotetext{
${ }^{3}$ Embora não tivesse assumido a disciplina na ocasião, o professor Luis Cláudio tem sido um grande colaborador do Núcleo. Na nossa organização, ele é lembrado como “membro efetivo”, do mesmo jeito que outros também grandes colegas: Marina Massimi (USP-RP), Regina Campos Freitas (UFMG), Emanuel Tourinho (UFPA), Josef Brožek (USA) e todos os ex-doutorandos e mestrandos de qualquer dos três Programas em Psicologia da PUC-SP que defenderam ou defenderão suas Dissertações e Teses em História da Psicologia.

${ }^{4}$ Hoje o Núcleo acrescenta ainda um P - Niephpsi - pois que inclui agora a Linha de Pesquisa em HP no Brasil, do Programa de Psicologia da Educação da PUC-SP, que a professora Mitsuko Antunes coordena.
} 
de estudo. Assim nossos doutorandos puderam conhecer, pessoalmente e por leitura, além de Luis Cláudio Figueiredo (PUC-SP e USP), que no curso de 86 lhes apresentou sua primeira versão de Matrizes do pensamento psicológico, os professores pesquisadores Antonio Gomes Penna (UFRJ), Renato Mezán (PUC-SP), Isaías Pessotti (USP-RP), Josef Brožek (EUA), Robert Farr (GRB), Regina Helena Campos Freitas (UFMG). Mas, além de professores desse porte, nossa estratégia de aproximação permitia trazer para o Núcleo pesquisadores novos, mestrandos e doutorandos que iam defendendo suas dissertações e teses na área: Marina Massimi (USP: 1985 e 1989), Maria Amália Andery e Teresa Maria Pires Sério (PUC-SP: 1990), Mitsuko Antunes (PUC-SP: 1991), Mário Angelo Silva e Odair Sass (PUCSP: 1992), Raul Pacheco Filho (USP: 1993), Nilza Micheletto (PUC-SP: 1995), Cristina Silva e Flávia M. S. Pereira Silva (PUC-SP: 1996), Marcos Ribeiro Ferreira e Alex Moreira Carvalho (a defender em 1997). E pesquisadores de outras áreas, cuja aproximação se revelou extremamente necessária, seja por causa dos conhecimentos que têm a oferecer (da História: Lilian Scwarcz, Denise Bernuzzi de Sant'Anna; da Antropologia), seja por causa das relações estreitas entre a Psicologia e tantas outras áreas (Medicina, Educação, Filosofia).

Aprendemos então que, se não havia muita pesquisa no Brasil em História da Psicologia, havia sim muita gente defendendo e trabalhando por sua importância na formação em psicologia, tanto na formação de pesquisadores (nosso intuito inicial) como na própria formação do psicólogo. E que, ao se encontrarem, passavam a aproveitar conosco a sombra que a árvore parecia fornecer.

Tivemos semestres incríveis, nestes doze anos de Núcleo. Acontecendo uma vez a cada dois ou três semestres, o curso História da Psicologia para Doutorado veio tendo um programa diferente a cada vez, sempre com objetivos colocados de forma a atender tanto ao crescimento do Núcleo como aos interesses dos doutorandos que, em determinado momento, têm que cumprir créditos nessa disciplina. O primeiro (1984) teve como objetivo apenas "conhecer quem pesquisa em HP no país". O próximo (1997) deverá propiciar a discussão de "o que a preocupação com a história” acrescentaria ao seu projeto de tese; vamos ouvir os projetos dos doutorandos e definir, com cada um deles, uma linha possível de considerações, que serão objeto de três atividades: debates sobre as diversas linhas levantadas com pesquisadores convidados, uma leitura relativa à 
linha que lhe cabe e um relatório final sobre a implicação desse estudo em seu projeto. Entre estes dois planos, tivemos oportunidade de: "conhecer os manuais de HP existentes nas Bibliotecas da PUC-SP e USP”; “analisar cursos de HP em diversas universidades do país” (aproveitando que boa parte de nossos doutorandos nesse semestre eram professores universitários de instituições as mais diversas); "ler e discutir os originais de Matrizes do pensamento psicológico”, de Luís Cláudio Figueiredo; “analisar texto e principais referências do artigo Does the History of Psychology an object? de Roger Smith ${ }^{5}$ (1988)"; "lendo capítulos escolhidos em História da vida privada, de Ariès e Duby (vol.1-1989, vol.21990, vo1.3-1991 e vo1.41991) e, com auxílio de rápidas descrições sobre os períodos em foco (elaboradas pelos próprios doutorandos), analisar a questão da historicidade do objeto da psicologia”; e, finalmente, "ler e discutir resenhas críticas de livros em HP publicadas no Journal of the History of Behavioral Sciences (1990-5)”.

Se é que se fazia alguma coisa, era isto: oferecíamos um lugar para as pessoas se encontrarem e trocarem resultados de estudo e pesquisa, enquanto nós e nossos doutorandos, ouvindo-as e debatendo com elas seus projetos, e lendo e debatendo entre nós e com elas uma diversa bibliografia de interesse para a área, íamos cumprindo, eles - seus créditos obrigatórios em HP, e o Núcleo - seu propósito de manter a História da Psicologia como um objeto de estudo no Programa. Menos que um espaço, apenas um lugar para estudar HP. Mesmo assim, com alguns produtos: além de Teses e Dissertações, foi destes estudos que saíram em 86 um Caderno PUC e trabalhos como o de Mônica Galano - A influência dos psicanalistas argentinos no Brasil na década de 70”6 . E, em 97, deverá sair um volume com resenhas críticas de livros em HP publicados nos últimos dez anos.

\section{As histórias do IPUC-SP na Fundação Aniela e Tadeusz Ginsberg}

A segunda experiência foi, esta sim, trabalhosa. E quando digo trabalhosa não quero dizer menos agradável. Apenas mais desafiante, mais exigente. Enquanto no Núcleo apenas estudávamos, na FATG pretendíamos orientar estudantes da graduação em pesquisa em HP, e isto a gente nunca

\footnotetext{
${ }^{5}$ Artigo publicado em History of Human Sciences (vol.1, n.2, out.1988, pp. 147-77).

${ }^{6}$ Publicado em Insight: Psicoterapia, Ano V, n ${ }^{\circ 4}$, agosto de 1995.
} 
tinha feito. De todo modo, o que se pretendia era ainda a criação e montagem de um lugar para se estar fazendo pesquisa em Psicologia.

A Fundação Aniela e Tadeusz Ginsberg foi criada para dar bolsa a estudantes de Psicologia. Ao final de 88 ela se instala com uma intenção muito clara: a de "incentivar estudantes a pesquisar", como condição de obtenção de bolsas, tendo em vista que a própria Fundação não dispunha de dinheiro para assegurar bolsas de outro tipo. Contando com a ajuda de professores que, como nós, davam de seu tempo pessoal para isso, buscamos na História da Psicologia um tema para interessar estudantes: o estudo da história de sua própria .escola. Tendo como atração a oportunidade de vir a ter uma bolsa-pesquisa, estudantes se aproximavam da Fundação Aniela com algum tema ou idéia para pesquisar, ou apenas pensando em aprender mais um pouco sobre pesquisa. ${ }^{7} \mathrm{E}$ encontravam um grupo trabalhando com documentos os mais diversos: uma Revista editada pela Psicologia da PUC-SP de 1955 a 1973; um Boletim mais velho ainda (1952-54); um vídeo registrado por ocasião dos 25 anos da profissão de psicólogo (1987), no qual dez professores falavam de seu currículo quando estudantes na própria PUC-SP; algumas maletas com materiais para diagnóstico infantil; e teses defendidas no primeiro curso de especialização em Psicologia realizado na Faculdade de Filosofia São Bento (1958-60). E um sem número de textos - documentos acadêmicos relativos à administração da Psicologia nessa Universidade desde sua instalação em 1946: programas, currículos, livros de atas, boletins de notas...

Diferentemente do que ocorre nas universidades em geral, aqui quem tinha que ter objetivos era o estudante. Não havia nada programado para ele, a não ser encontros. Melhor dizendo, nem os encontros eram programados, a não ser pela idéia de que tínhamos que ajudá-los a ter "um plano de estudos", e isto era feito conversando. Conosco e com outros alunos em condições parecidas. Basicamente, a idéia era a seguinte: se o estudante pretende algo que seu curso não está possibilitando (e essa era,

\footnotetext{
${ }^{7}$ Interessante verificar a variedade de razões dos estudantes para procurar a Fundação: "um lugar para continuar pesquisa iniciada em sala"; "atividade para encher o tempo entre aulas”; "procura de um professor para orientar assunto que não existe no currículo"; "vontade de ter uma pesquisa individual mas com um grupo para estar apoiando"; "oportunidade de fazer uma pesquisa (coisa proibida aos primeiranistas, de acordo com as agências de fomento)”...
} 
pelo menos no início, a razão para nos procurar), ele precisa nos dizer o que quer estudar.

Então, a partir do manuseio dos documentos disponíveis e participando de encontros (quase sempre em grupo) para conversar sobre o que iam vendo e ouvindo, estudantes passaram a montar seus projetos de pesquisa tendo como objetivo responder a perguntas as mais diversas. ${ }^{8} \mathrm{E}$ se o material e o grupo não o inspiravam a continuar conosco, nós o encaminhávamos a algum professor que o orientasse em projeto alheio ao nosso tema. ${ }^{9}$ Todo o conjunto tinha um nome: Histórias do IPPUC-SP, e começou com um "projeto-matriz" - que permitiu a solicitação das primeiras bolsas. Em quatro anos tivemos na Fundação 46 estudantes da graduação, muitos professores e uma mestranda (que viera para o grupo para treinar algumas habilidades em pesquisa e acabou mudando seu tema inicial para HP: Mônica Azevedo). E bolsas de diferentes agências: Cepe/PUC, CNPq (tanto Pibic como “de balcão”), Fapesp, Capes.

Muitos dos estudantes que participaram deste projeto têm apresentado suas pesquisas em encontros científicos. Alguns são hoje mestrandos, boa parte dos quais acredita ter descoberto aí seu interesse por pesquisa (para dois ou três mais exaltados, foi aí que descobriram seu verdadeiro interesse pela Psicologia); e há ainda os que fazem sua pesquisa de mestrado em HP, como Alessandra Pimentel, Cristina Franco Alves, Sandra L. do Nascimento, Sonia Regina Bueno. Para nós, da Fundação ${ }^{10}$, um rico material para nossa análise da "iniciação científica como uma

\footnotetext{
${ }^{8}$ As perguntas dos alunos variavam entre curiosidade por um passado que lhes era agora apresentado (o que era a Psicologia quando o IPPUC-SP foi criado; quem foi Aniela Ginsberg, o que ela pesquisava; a relação professor-aluno e a pesquisa nos currículos do IP...) e sua transformação em problemas mais elaborados (o IP e o projeto da Igreja de formação de lideranças católicas; as alterações curriculares na PUC: relação com o debate na comunidade científica sobre a formação em psicologia; como conhecer uma instituição estudando suas publicações: - os artigos, as resenhas, notícias sobre congressos; o pesquisar nas décadas de 50 e 60: a contribuição do IP...). A relação completa dos projetos realizados no período estará no texto referido na nota 1.

9 Tivemos, nesta condição, dois alunos com bolsa na área de saúde (Fapesp e OMS), uma em psicologia ambiental (CNPq), uma sobre práticas alternativas (CNPq, depois Fapesp) e cinco em psicologia na comunidade (Funap).

${ }^{10}$ A equipe interessada neste tema inclui ainda Sandra Bettoi e Eveline Bouteiller Kavakama.
} 
questão de gosto" ${ }^{11}$. E ainda um produto planejado, mas a realizar: a publicação de um volume com algumas das histórias então contadas.

\section{A produção de documentos para uma história de um Programa de Pós- Graduação que fará 30 anos em 1999}

A terceira experiência que relataremos é também a mais recente. Em fevereiro de 96, com a colaboração indispensável de mais quatro professoras do Programa de Psicologia da Educação da PUC-SP, oferecemos aos mestrandos e doutorandos um curso que, compactado em um mês, permitia créditos em pesquisa (uma das exigências do currículo). o objetivo geral era "buscar e analisar documentos que permitam ao Programa escrever uma história dos seus 30 anos”. ${ }^{12}$

Em um mês, trabalhando em tempo integral (e até mais, porque o entusiasmo do grupo e o volume de documentos nos levaram a isso), sete mestrandos, três doutorandos e quatro professoras trabalharam com três diferentes interesses: (a) a concepção de Psicologia da Educação no Programa ao longo destes 30 anos; (b) os currículos para formação de mestrandos e doutorandos, desde a sua criação; e (c) a produção de teses e dissertações no período. Grupos mistos (estudantes e professoras) se formaram, e cada grupo ia procurando e descobrindo os documentos definidos, em conjunto com o grupo maior, como necessários e suficientes para desenvolver seu tema. Enquanto isso, com duas mestrandas que já trabalhavam conosco em HP, formávamos um quarto grupo - que atendia ao objetivo geral do curso: a análise e organização dos documentos que iam sendo encontrados. Ao final do mês, tínhamos já uma proposta de organização para os arquivos correntes e permanentes do Programa e um total de 75 tipos documentais identificados, integrando o material que será posto à disposição dos interessados em escrever a ou as histórias do

\footnotetext{
${ }^{11}$ Artigo a publicar, possivelmente em Temas em Psicologia, revista da SBP. A expressão "gosto" tem aqui um papel claro - o de lembrar tanto o gosto/paladar como o julgamento de valor. Cabe dizer ainda que o título do artigo deliberadamente traz a iniciação científica em minúsculo (para sinalizar mais que a IC formalmente definida pelas agências de fomento) e termina com uma interrogação.

${ }^{12} \mathrm{O}$ que tínhamos era mais que um curso, era uma pesquisa encomendada pela coordenação do Programa e que envolveu, além das atividades e do pessoal acima citado, especialistas em arquivologia (do Centro de Documentação e Informação Científica da PUC-SP), que orientaram no plano de organização do material encontrado.
} 
Programa. Um primeiro relato do trabalho deste subgrupo foi apresentado na $48^{\mathrm{a}}$ Reunião Anual da SBPC (Pimentel e Bueno, 1996). Outro, com análises mais específicas, será apresentado em 97, na Reunião Anual de Ribeirão Preto (Guedes, Bueno e Pimentel).

Com um procedimento que incluiu, além de muito trabalho individual e em subgrupo, encontros do grupo maior sempre que solicitados (para que todos conhecessem os documentos que iam sendo localizados, para se definir a oportunidade e ou necessidade de seu uso, bem como para as aulas sobre análise de fontes e documentos), o projeto dependeu ainda de leituras que iam sendo necessárias - tanto para o tema geral (lidar com documentos primários) como para os temas de cada grupo. O curso se completou com apresentação dos relatórios finais, que os grupos escreveram ao longo de março. Assim, tendo analisado (a) 30 ementas diferentes de cursos intitulados Psicologia da Educação ministrados no primeiro semestre aos mestrandos entre 1969 e 1976, (b) 322 resumos de teses e dissertações defendidas no período e (c) os planos curriculares e regulamentos que o Programa teve ao longo destes 27 anos, os três outros subgrupos realizaram pesquisas que constituem importante contribuição para uma história da pós-graduação na área, no país. Formas finais serão oportunamente comunicadas em encontros, eventualmente transformados em artigos. $^{13}$

\section{Concluindo}

Eis aí as experiências prometidas ao início, e os comentários que este espaço para analisá-las podia comportar. O momento agora é de organizar e divulgar tudo que foi sendo produzido (bibliografias comentadas, por exemplo, ou uma relação de pessoas interessadas em HP, etc.); é o que estamos fazendo na Fundação Aniela e Tadeusz Ginsberg, que se compromete hoje também com o objetivo de "referenciar e difundir a psicologia”. Mas é tempo também de analisar o que isto pode significar para o estudo de HP em nosso meio - para que de fato saibamos defender, com dados, nossos próprios argumentos sobre a importância da História da Psicologia na formação de psicólogos e de pesquisadores.

\footnotetext{
${ }^{13}$ Relatórios arquivados no Programa de Estudos Pós-graduados em Psicologia da Educação.
} 